\title{
Effects of local and landscape factors on grassland plant diversity
}

\author{
Dissertation \\ zur Erlangung des Doktorgrades \\ der Fakultät für Agrarwissenschaften \\ der Georg-August-Universität Göttingen
}

vorgelegt von

Sebastian Klimek

geboren in Marburg

Göttingen, September 2006 
D 7

1. Referent: Prof. Dr. Johannes Isselstein

2. Korreferent: Prof. Dr. Teja Tscharntke

Tag der mündlichen Prüfungen: 16.11.2006 


\section{CONTENTS}

1 General introduction: Effects of local and landscape factors on grassland plant diversity

Introduction $\quad 6$

Study areas and sampling designs $\quad 7$

Main objectives $\quad 10$

Results and conclusions $\quad 12$

References 14

2 Plant species richness and composition in managed grasslands: the 18 relative importance of field management and environmental factors

$\begin{array}{ll}\text { Abstract } & 19\end{array}$

$\begin{array}{ll}\text { Introduction } & 20\end{array}$

Materials and methods $\quad 22$

Results 28

Discussion $\quad 34$

References $\quad 39$

3 Opposing effects of local and landscape factors on plant species richness 44 in mown vs. grazed grassland

$\begin{array}{lr}\text { Summary } & 45 \\ \text { Introduction } & 46 \\ \text { Materials and methods } & 48 \\ \text { Results } & 54 \\ \text { Discussion } & 57 \\ \text { References } & 62 \\ \mathbf{4} \text { Effects of management regime, nitrogen fertilisation and abiotic factors } & \mathbf{6 8}\end{array}$ on local-regional patterns of plant species richness in managed temperate grasslands

Abstract 
$\begin{array}{ll}\text { Introduction } & 70\end{array}$

$\begin{array}{ll}\text { Materials and methods } & 72\end{array}$

Results

$\begin{array}{ll}\text { Discussion } & 82\end{array}$

$\begin{array}{ll}\text { References } & 87\end{array}$

$\begin{array}{ll}\text { Appendix } & 92\end{array}$

5 Effects of local factors on plant species richness and composition of 94 Alpine meadows

$\begin{array}{lr}\text { Abstract } & 95 \\ \text { Introduction } & 96 \\ \text { Materials and methods } & 97 \\ \text { Results } & 101 \\ \text { Discussion } & 104 \\ \text { References } & 108\end{array}$

6 Patterns of plant species density in Alpine hay meadows: local vs. 111 landscape controls

$\begin{array}{lr}\text { Abstract } & 112 \\ \text { Introduction } & 113 \\ \text { Materials and methods } & 114 \\ \text { Results } & 119 \\ \text { Discussion } & 121 \\ \text { References } & 124\end{array}$

$\begin{array}{ll}\text { Summary } & 128\end{array}$

$\begin{array}{lr}\text { Zusammenfassung } & 130\end{array}$

$\begin{array}{lr}\text { Acknowledgements } & 132\end{array}$

List of publications $\quad 134$

$\begin{array}{lr}\text { Curriculum vitae } & 136\end{array}$ 


\section{CHAPTER}

General introduction:

Effects of local and landscape factors on grassland plant diversity 


\section{Introduction}

Conserving biodiversity and the services it provides is an urgent task for our society (Balmford et al., 2005). Temperate semi-natural grasslands resulting from a long history of traditional lowintensity farming systems have been recognised as an important biodiversity resource in agricultural areas within the European Union (Söderström et al., 2001; WallisDeVries et al., 2002; Myklestad \& Sætersdal, 2004). Such man-made grasslands are of great nature conservation interest, as they may harbour a very high small-scale species density compared to other community types (Pärtel et al., 1996), and make an important contribution to the total biodiversity of the rural landscapes (Nösberger \& Rodriguez, 1996).

Over the last decades, both the decrease of the area and the fragmentation of semi-natural habitats caused a dramatic decline of biodiversity at local and regional scales (Critchley et al., 2004; Krauss et al., 2004; Balmford et al., 2005). These processes have been largely attributed to the intensification of land-use practices (Benton et al., 2003; Tscharntke et al., 2005; Donald \& Evans, 2006). At the local field scale, changes in farm management practices associated with agricultural intensification resulted in simplified, species-poor grassland communities of low nature conservation value, primarily due to greater fertiliser inputs and increased defoliation frequencies (Fuller, 1987; Garcia 1992; Plantureux et al., 2005). At the regional scale, agricultural intensification implicated farm enlargement and field consolidation accompanied by abandonment of less fertile soils with marginal yields (Benton et al., 2003; Tscharntke et al., 2005). As a consequence, the formerly large regional variety of grassland utilisation systems strongly decreased, benefiting spatially and structurally uniformly managed grassland areas that resulted in a homogenisation of the landscape. Besides homogenisation (Jongman, 2002), the fragmentation of the remaining semi-natural grasslands caused species loss on the long run as ecological processes such as dispersal, recruitment and persistence of local populations were limited due to reduced connectivity (Kiviniemi \& Eriksson, 2002; Helm et al., 2006). Thus, patterns of species diversity are the result of processes operating at both local and regional scales (Ricklefs, 1987; Collins et al., 2002; Münzbergová, 2004).

To improve the ability to explain variation in patterns of species diversity, it is therefore essential to adopt a multi-scale approach. In general, it is widely accepted that species richness in a community is determined by local processes such as competition, disturbance regime and biotic interactions (Ricklefs, 1987; Grace, 1999; Grime, 2001). Moreover, there is evidence that the community structure and its dynamics are governed by the regional species pool and dispersal 
limitations (Pärtel et al., 1996; Poschlod et al., 2005). Management regimes like mowing and livestock grazing affect plant species diversity in grasslands, especially by their intensity and continuity (Smith et al., 1996). One the one hand, high grassland biodiversity has been associated with decreased cutting frequency and late mowing (Moog et al., 2002). On the other hand, vascular plant species richness of semi-natural grasslands has been demonstrated to benefit from low-tomoderate intensity livestock grazing at stocking rates less than one livestock unit per hectare (Collins et al., 1998; Duru \& Hubert, 2003). It has further been shown that grazing animals can alter grassland vegetation by creating heterogeneity in the soil and sward structure through selective grazing, trampling, deposition of excreta (Olff \& Ritchie, 1998; Adler et al., 2001; Rook et al., 2004), and by acting as dispersal agents (Fischer et al., 1996). As most species-rich grasslands are adapted to low nutrient conditions, high amounts of nitrogen fertiliser inputs generally decreased the species richness (Jacquemyn et al., 2003; Plantureux et al., 2005).

Besides management regime and field management intensity, recent work showed that plant species richness varies in response to topography-related environmental factors such as site-specific solar radiation and slope angle (Pykälä et al., 2005; Bennie et al., 2006). Furthermore, Sebastiá (2004) found that soil fertility was the main environmental gradient structuring subalpine, calcareous grassland communities at the landscape scale. There is also evidence that on small spatial scales soil heterogeneity affects the distribution of plant species in grasslands (Reynolds et al., 1997). In particular, it is well established that the phosphorus (P) soil content is an important determinant for the reconstruction or conservation of species-rich meadows (Janssens et al., 1998; Tracy \& Sanderson, 2000; Critchley et al., 2002).

In this study, we generally aimed to provide understanding of the underlying local and landscape factors that control vascular plant species diversity in managed grasslands. In most analyses, we used partitioning methods such as variation and hierarchical partitioning, which are novel statistical approaches that provide deeper understanding of the relative importance of different sets of explanatory variables for biodiversity patterns (Heikkinen et al., 2005). In one analysis, we used the additive partitioning approach to investigate the effects of management regime, nitrogen fertilisation and abiotic factors on local-regional patterns of plant species richness.

\section{Study areas and sampling designs}

The studies were conducted in two different regions: the administrative district of Northeim located in Lower Saxony, Germany and several districts of the province Trento in North-East Italy. 
The Northeim district covered an area of $c .1260 \mathrm{~km}^{2}$ (approximate north-south boundaries $51^{\circ} 95^{\prime} \mathrm{N}$ to $51^{\circ} 61^{\prime} \mathrm{N}$ ). The mean annual temperature was $8.7^{\circ} \mathrm{C}$, and the annual precipitation averaged $645 \mathrm{~mm}$. The relief gradient was rather small, with altitudes above sea level (a.s.1.) ranging from $72 \mathrm{~m}$ in the lowlands to $527 \mathrm{~m}$ in the wooded hillsides of the western part of the study area. The district was dominated by agricultural land use, covering c. $38 \%$ of the region, and large contiguous forest-covered areas in the hilly regions. Within the agricultural landscape, patchily distributed fragments of agriculturally improved, species-poor grassland were mainly located in the lowland areas (Fig. 1). Semi-natural, species-rich grassland that had not experienced any agricultural improvement were predominantly situated in the steeper areas.

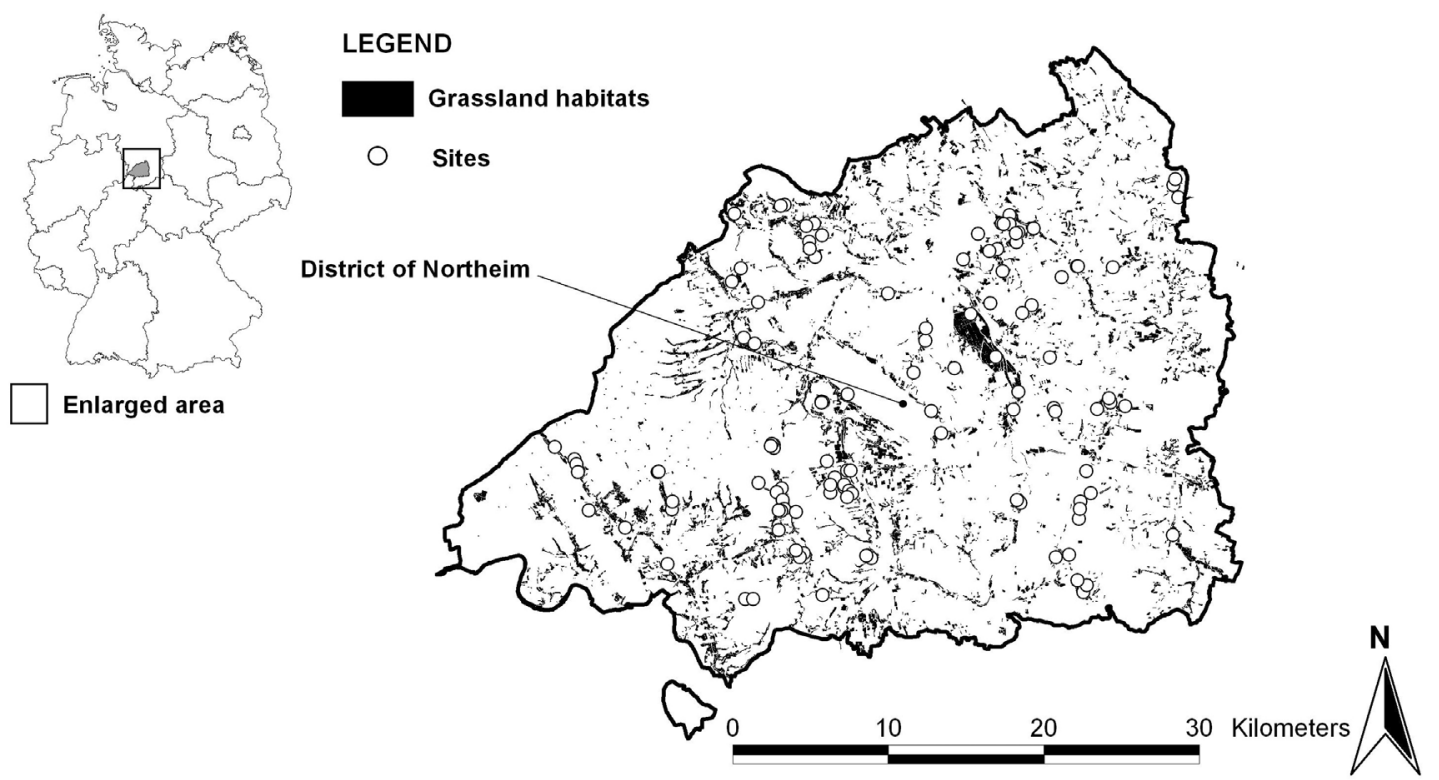

Fig. 1 Map of the research area in Lower Saxony, Germany, showing the sampled grassland sites $(\mathrm{n}=117)$.

Grassland vegetation was recorded in two field surveys undertaken during May/June 2002 and 2004. We sampled a total of 117 managed grassland sites that were selected randomly, covering a complete gradient from agriculturally improved, species-poor grassland to semi-natural, speciesrich grassland that had not experienced agricultural improvement. At each managed grassland site, three circular sample units of $12.6 \mathrm{~m}^{2}$ (radius $2 \mathrm{~m}$ ) each were established at a minimum distance of $10 \mathrm{~m}$ from each other for the assessment of vascular plant species richness and composition. Edge effects were avoided by excluding a 10-meter wide buffer zone from the field boundary. In each 
sample unit, all plant species were identified to species level. Species nomenclature followed that of Wisskirchen and Haeupler (1998).

In North-East Italy, the research was carried out in five administrative districts of the Trento Province: 1) Low Valsugana and Tesino, 2) High Valsugana, 3) Primiero, 4) Fiemme Valley and 5) Fassa Valley (Fig. 2). The geology was heterogeneous with calcareous, siliceous bedrocks and mixed sediments. The mean annual rainfall in the area was $c .1050 \mathrm{~mm}$. The mean annual temperature at the minimum altitude considered $\left(320 \mathrm{~m}\right.$ a.s.1.) was ca. $12{ }^{\circ} \mathrm{C}$, while it was ca. $3.5^{\circ} \mathrm{C}$ at the maximum altitude (1910 $\mathrm{m}$ a.s.1.). The study region consisted of two main landscape contexts concerning topography and land-use: 1) relatively highly urbanised flat valley, where the agricultural and zootechnic activities were concentrated; here, the agricultural landscape was characterised by hay meadows, forage cultures, and woody agricultural cultures (vine and apple); 2) little urbanised steeper mountain slopes mainly covered by forests, pastures and secondarily by mown meadows.

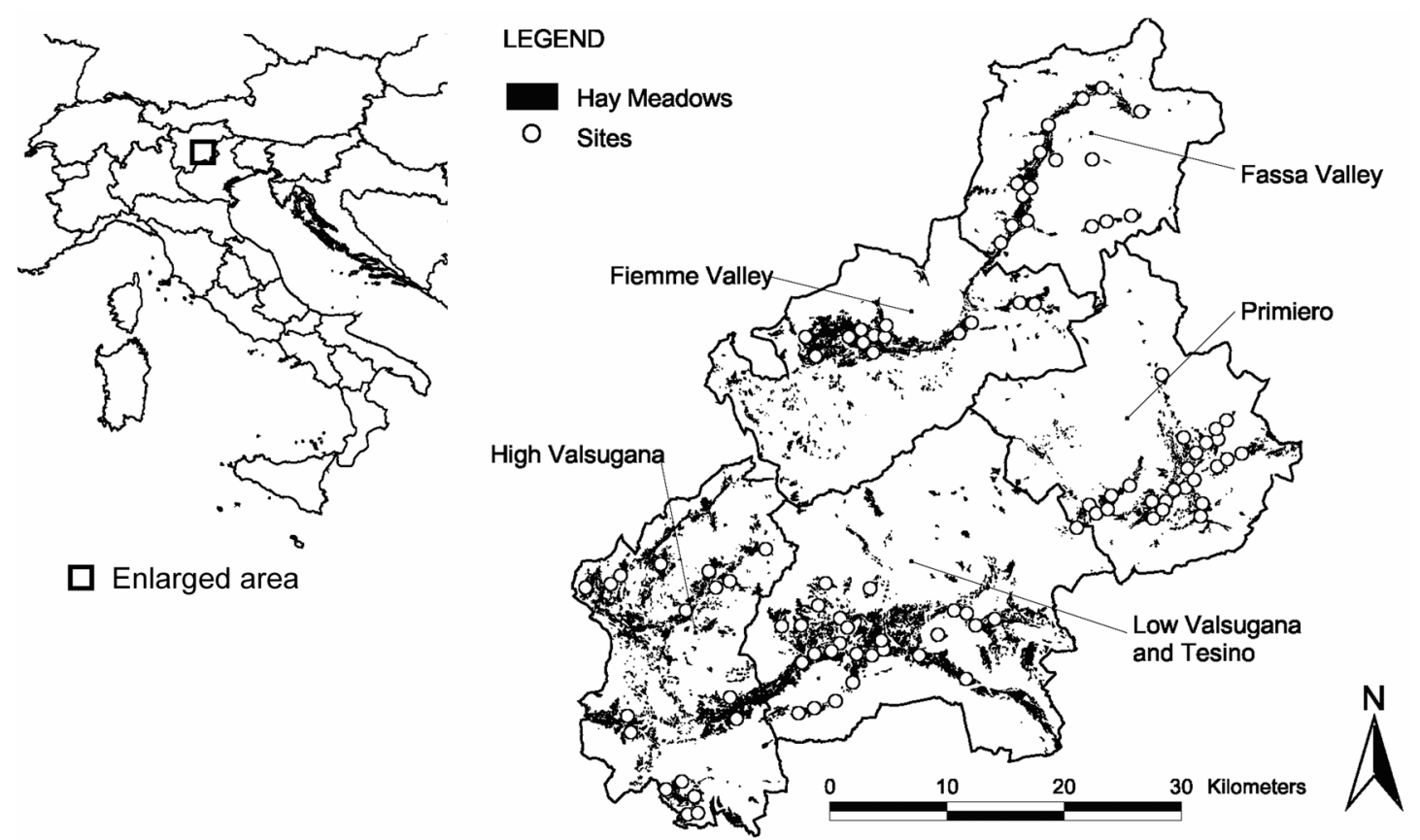

Fig. 2 Map of the research area in the five administrative districts of the Trento province, NE Italy, showing the sampled meadow sites $(\mathrm{n}=99)$.

We selected 99 meadows from the five districts in close collaboration with the farmers using as selection criterion the characteristics of agricultural management practices in order to sample a 
large gradient of management intensity. In each selected meadow, a square of $10 \times 10 \mathrm{~m}^{2}$ was randomly established for the assessment of vascular plant species richness and density. Edge effects were avoided by excluding a 10-m buffer zone from the management unit boundaries. All vascular plants in the square were identified at the species level and recorded once before the first and once before the second cut.

\section{Main objectives}

This thesis aimed at contributing to the understanding of the relative effects of local and landscape factors on plant species diversity patterns in managed temperate grasslands. The effects of local management, local abiotic factors and landscape variables have been comparatively little studied in both Central-European agricultural landscapes and Alpine areas. A summary of the data, approaches and major statistical methods used in each of the five following chapters is given in Table 1.

Table 1. A summary of the geographical location of the investigated grassland sites, the biological response monitored, the predictors, and the major statistical methods used in each of the five following chapters of this thesis.

\begin{tabular}{|c|c|c|c|c|c|}
\hline & Chapter 2 & Chapter 3 & Chapter 4 & Chapter 5 & Chapter 6 \\
\hline $\begin{array}{l}\text { Geographical } \\
\text { location }\end{array}$ & $\begin{array}{l}\text { District of } \\
\text { Northeim, } \\
\text { Germany }\end{array}$ & $\begin{array}{l}\text { District of } \\
\text { Northeim, } \\
\text { Germany }\end{array}$ & $\begin{array}{l}\text { District of } \\
\text { Northeim, } \\
\text { Germany }\end{array}$ & $\begin{array}{l}\text { Districts of } \\
\text { the province } \\
\text { Trento, Italy }\end{array}$ & $\begin{array}{l}\text { Districts of } \\
\text { the province } \\
\text { Trento, Italy }\end{array}$ \\
\hline $\begin{array}{l}\text { Number of } \\
\text { grassland sites }\end{array}$ & 117 & 60 & 60 & 56 & 99 \\
\hline Response variables & $\begin{array}{l}\text { Species } \\
\text { richness } \\
\text { Species } \\
\text { composition }\end{array}$ & $\begin{array}{l}\text { Species } \\
\text { richness }\end{array}$ & $\begin{array}{l}\text { Diversity } \\
\text { components } \\
(\alpha-, \beta-, \text { and } \\
\gamma \text {-diversity) }\end{array}$ & $\begin{array}{l}\text { Species } \\
\text { richness } \\
\text { Species } \\
\text { composition }\end{array}$ & $\begin{array}{l}\text { Species } \\
\text { density }\end{array}$ \\
\hline Predictor variables & $\begin{array}{l}\text { Management } \\
\text { Environment } \\
\text { Spatial } \\
\text { location }\end{array}$ & $\begin{array}{l}\text { Local } \\
\text { topography } \\
\text { Local } \\
\text { management } \\
\text { Landscape } \\
\text { structure }\end{array}$ & $\begin{array}{l}\text { Management } \\
\text { regime } \\
\text { Nitrogen } \\
\text { fertilisation } \\
\text { Slope angle } \\
\text { Soil quality }\end{array}$ & $\begin{array}{l}\text { Soil } \\
\text { Topography } \\
\text { Management }\end{array}$ & $\begin{array}{l}\text { Local } \\
\text { management } \\
\text { Local } \\
\text { environment } \\
\text { Landscape } \\
\text { structure }\end{array}$ \\
\hline $\begin{array}{l}\text { Major statistical } \\
\text { methods }\end{array}$ & $\begin{array}{l}\text { Variation } \\
\text { partitioning } \\
\text { Ordination }\end{array}$ & $\begin{array}{l}\text { Variation } \\
\text { partitioning } \\
\text { Hierarchical } \\
\text { partitioning }\end{array}$ & $\begin{array}{l}\text { Additive } \\
\text { partitioning } \\
\text { ANCOVA }\end{array}$ & $\begin{array}{l}\text { Variation } \\
\text { partitioning } \\
\text { Ordination }\end{array}$ & $\begin{array}{l}\text { Variation } \\
\text { partitioning } \\
\text { Hierarchical } \\
\text { partitioning }\end{array}$ \\
\hline
\end{tabular}


In each of the five chapters, the objectives are summarised as follows:

CHAPTER 2 (i) determination of the relative importance of local field management, environmental and spatial variables on plant species richness, (ii) analysis of the effects of the studied explanatory variables on plant species composition, and (iii) examination if plant species richness and composition are affected differently by the type of management regime (meadow, pasture and mowed pasture).

CHAPTER 3 (i) comparison of the relative importance of local and landscape factors on plant species richness in mown meadows and grazed grasslands, and (ii) testing whether plant species richness of contrasting management regimes is related to landscape structure at different spatial scales.

CHAPTER 4 (i) comparison of the local-regional patterns of plant species richness between mowing and grazing management, (ii) importance of the grassland management regime compared with the influence of nitrogen fertilisation and abiotic environmental factors on the additive species diversity components, and (iii) testing whether the effect of grassland management regime differed between all plant species compared to forb and indicator species.

CHAPTER 5 (i) determination of the relative effects of local soil, topography, and field management explanatory variables on species richness and composition of mown meadows in an area of the Southern Alps.

CHAPTER 6 (i) elucidation of the determinants of species density in Alpine hay meadows by decomposing the variation into local (field management and abiotic environment) and landscape (landscape structure) components. 


\section{Results and conclusions}

Most of the explained variation in plant species richness was related to the joint effect of local field management and environmental variables. The applied variation partitioning approach revealed that the pure effect of spatial variables contributed relatively little to explaining variation in both plant species richness and species composition. The largest fractions of explained variation in plant species composition were accounted for by the pure effects of environmental and local field management variables. Moreover, the results revealed that the main mechanisms by which these sets of explanatory variables affect plant species vary according to the type of management regime under study. From our findings we could conclude that particularly a reduction of nitrogen fertilisation on meadows and grazing at a low stocking rate on pastures can help to conserve biodiversity. (CHAPTER 2)

The partitioning approaches revealed contrasting responses of plant species richness to local and landscape factors depending on the management regime. While plant species richness of meadows was solely determined by a negative effect of nitrogen fertilisation, plant species richness of pastures was affected by both local and landscape factors. Thus, in pastures, local site conditions such as steep slopes and low soil quality were positively related to plant species richness. Grazing at moderate stocking rates also contributed to high plant species richness. Our results indicated an opposing effect of landscape context for the management regime and. Plant species richness of meadows was not affected by landscape context whereas plant species richness of pastures significantly decreased with increasing percentage of arable land in the surrounding landscape. Our results demonstrate that low to moderate intensity livestock grazing enhances plant species richness in managed grasslands. Securing coherent areas of extensively managed pastures at the landscape level by means of agri-environment schemes could combine biodiversity improvements with reduced costs for pasture management to the farmer. (CHAPTER 3)

Using the additive partitioning approach, we quantified $\alpha$-, $\beta$ - and $\gamma$-diversity components for each management regime at two spatial scales, the local field scale and the regional scale. $\alpha-, \beta-$ and $\gamma$ diversity were higher in grazed pastures than in mown meadows at both spatial scales. Our results revealed that for both management regimes the heterogeneity between the grassland parcels ( $\beta$ diversity) at the regional scale contributed most to the overall observed regional $\gamma$-diversity (proportions ranged from 80 to $91 \%$ ). Low application rates of nitrogen fertilisers and abiotic 
environmental conditions such as soils with a low nutrient status and steep slopes positively affected vascular plant species richness in grasslands. Although the management regime did not show the dominant effect in explaining local-regional patterns of species richness, the results indicate an indirect contribution of low-to-moderate livestock grazing to a high species richness as pastures were mainly located on steeply sloping grounds with poor soil quality. We conclude, that the maintenance of a large variety of grassland utilisation systems can allow the conservation of a wide diversity of grassland plants. Particularly, the maintenance and re-establishment of grazing along with a spatially varied disturbance regime at large areas with heterogeneous abiotic environmental conditions could facilitate successful management of vascular plant species diversity. (CHAPTER 4)

Species richness was mostly controlled both by the short-term effect of nitrogen fertilisation, and by the long-term effect of soil phosphorus accumulation. The decrease of plant species number on the most fertile meadows was the consequence of the dominance of few competitors or ruderals, which prevented the establishment of small stress-tolerant species. In contrast to species richness, plant species composition presented important pure effect of topography (altitude and slope). Species composition depended on several topography, soil, and field management factors. Thus, for both conservation and restoration of species-rich hay meadows, it is necessary to maintain a low level of soil P content, and to prevent the abandonment of parcels on steep slopes and in marginal areas, because these hosted the highest level of plant diversity. (CHAPTER 5)

Partitioning analyses revealed that species density was affected primarily by local determinants. Species number per area tended to increase in extensively managed meadows, and site conditions such as steep slopes, shallow soils, and increased elevation also contributed to enhance plant species density. Regarding the landscape determinants, a high proportion of urban elements affected species density negatively, while an increased amount of edges had an opposite effect. The landscape context probably operated by influencing the local pool of species that were potentially able to disperse into the sites. Moreover, a relatively high level of urbanisation could possibly cause additional nutrient inputs, not directly related to management, which intensified the detrimental effect of fertilisation. Our results corroborate the hypothesis that vascular plants, like several animal taxa, are significantly affected by the landscape context, although the local habitat quality explained a greater proportion of the variation in species density. (CHAPTER 6) 


\section{References}

Adler, P.B., Raff, D.A. \& Lauenroth, W.K. (2001) The effect of grazing on the spatial heterogeneity of vegetation. Oecologia, 128, 465-479.

Balmford, A., Bennun, L., Brink, B.T., Cooper, D., Côte, I.M., Crane, P., Dobson, A., Dudley, N., Dutton, I., Green, R.E., Gregory, R.D., Harrison, J., Kennedy, E.T., Kremen, C., LeaderWilliams, N., Lovejoy, T.E., Mace, G., May, R., Mayaux, P., Morling, P., Phillips, J., Redford, K., Ricketts, T.H., Rodriguez, J.P., Sanjayan, M., Schei, P.J., van Jaarsveld, A.S. \& Walther, B.A. (2005) The Convention on Biological Diversity's 2010 Target. Science, 307, 212-213.

Bennie, J., Hill, M.O., Baxter, R. \& Huntley, B. (2006) Influence of slope and aspect on long-term vegetation change in British chalk grasslands. Journal of Ecology, 94, 355-368.

Benton, T.G., Vickery, J.A. \& Wilson, J.D. (2003) Farmland biodiversity: Is habitat heterogeneity the key? Trends in Ecology and Evolution, 4, 182-188.

Collins, S.L., Knapp, A.K., Briggs, J.M., Blair, J.M. \& Steinauer, E.M. (1998) Modulation of diversity by grazing and mowing in native tallgrass prairie. Science, 280, 745-747.

Collins, S.L., Glenn, S.M. \& Briggs, J.M. (2002) Effects of local and regional processes on plant species richness in tallgrass prairie. Oikos, 99, 571-579.

Critchley, C.N.R., Chambers, B.J., Fowbert, J.A., Sanderson, R.A., Bhogal, A. \& Rose, S.C. (2002) Association between lowland grassland plant communities and soil properties. Biological Conservation, 105, 199-215.

Critchley, C.N.R., Burke, M.J.W. \& Stevens, D.P. (2004) Conservation of lowland semi-natural grasslands in the UK: a review of botanical monitoring results from agri-environment schemes. Biological Conservation, 115, 263-278.

Donald, P.F. \& Evans, A.D. (2006) Habitat connectivity and matrix restoration: the wider implications of agri-environment schemes. Journal of Applied Ecology, 43, 209-218.

Duru M. \& Hubert B. (2003) Management of grazing systems: from decision and biophysical models to principles for action. Agronomie, 23, 689-703.

Fischer, S., Poschlod, P. \& Beinlich, B. (1996) Experimental studies on the dispersal of plants and animals by sheep in calcareous grasslands. Journal of Applied Ecology, 33, 1206-1222.

Fuller, R.M. (1987) The changing extent and conservation interest of lowland grasslands in England and Wales: a review of grassland surveys 1930-84. Biological Conservation, 40, 281-300.

Garcia, A. (1992) Conserving the species-rich meadows of Europe. Agriculture, Ecosystems and Environment, 40, 219-232. 
Grace, J.B. (1999) The factors controlling species density in herbaceous plant communities: an assessment. Perspectives in Plant Ecology Evolution and Systematics, 2, 1-28.

Grime, J.P. (2001) Plant strategies, vegetation processes, and ecosystem properties. 2nd ed., Wiley, Chichester, UK.

Heikkinen, R.K., Luoto, M., Kuussaari, M. \& Pöyry, J. (2005) New insights into butterflyenvironment relationships using partitioning methods. Proceedings of the Royal Society, 272, 2203-2210.

Helm, A., Hanski, I. \& Pärtel, M. (2006) Slow response of plant species richness to habitat loss and fragmentation. Ecology Letters, 9, 72-77.

Jacquemyn, H., Brys, R. \& Hermy, M. (2003) Short-time effects of different management regimes on the response of calcareous grassland vegetation to increased nitrogen. Biological Conservation, 111, 137-147.

Janssens, F., Peeters, A., Tallowin, J.R.B., Bakker, R.M., Fillat, F. \& Oomes, M.J.M. (1998) Relation between soil chemical factors and grassland diversity. Plant and Soil, 202, 69-78.

Jongman, R.H.G. (2002) Homogenisation and fragmentation of the European landscape: ecological consequences and solutions. Landscape and Urban Planning, 58, 211-221.

Kiviniemi, K. \& Eriksson, O. (2002) Size-related deterioration of semi-natural grassland fragments in Sweden. Diversity and Distributions, 8, 21-29.

Krauss, J., Klein, A.-M., Steffan-Dewenter, I. \& Tscharntke, T. (2004) Effects of habitat area, isolation, and landscape diversity on plant species richness of calcareous grasslands. Biodiversity and Conservation, 13, 1427-1439.

Moog, D., Poschlod, P., Kahmen, S. \& Schreiber, K.-F. (2002) Comparison of species composition between different grassland management treatments after 25 years. Applied Vegetation Science, $5,99-106$.

Münzbergová, Z. (2004) Effect of spatial scale on factors limiting species distributions in dry grassland fragments. Journal of Ecology, 92, 854-867.

Myklestad, A. \& Sætersdal, M. (2004) The importance of traditional meadow management techniques for conservation of vascular plant species richness in Norway. Biological Conservation, 118, 133-139.

Nösberger, J. \& Rodriguez, M. (1996) Increasing biodiversity through management. Grassland Science in Europe, 1, 949-956.

Olff, H. \& Ritchie, M.E. (1998) Effects of herbivores on grassland plant diversity. Trends in Ecology and Evolution, 13, 261-265. 
Pärtel, M., Zobel, M., Zobel, K. \& van der Maarel, E. (1996) The species pool and its relation to species richness: evidence from Estonian plant communities. Oikos, 75, 111-117.

Plantureux, S., Peeters, A. \& McCracken, D. (2005) Biodiversity in intensive grasslands: Effect of management, improvement and challenges. Agronomy Research, 3, 153-164.

Poschlod, P., Tackenberg, O. \& Bonn, S. (2005) Plant dispersal potential and its relation to species frequency and co-existence. In: van der Maarel, E. (Ed.), Vegetation Ecology. Blackwell Science Ltd, USA, pp. 147-171.

Pykälä, J., Luoto, M., Heikkinen, R.K. \& Kontula, T. (2005) Plant species richness and persistence of rare plants in abandoned semi-natural grasslands in northern Europe. Basic and Applied Ecology, 6, 25-33.

Reynolds, H.L., Hungate, B.A., Chapin III, F.S. \& D'Antonio, C.M. (1997) Soil heterogeneity and plant competition in an annual grassland. Ecology, 78, 2076-2090.

Ricklefs, R.E. (1987) Community diversity: relative roles of local and regional processes. Science, 235, 167-171.

Rook, A.J., Dumont, B., Isselstein, J., Osoro, K., WallisDeVries, M.F., Parente G. \& Mills, J. (2004) Matching type of livestock to desired biodiversity outcomes in pastures - a review. Biological Conservation, 119, 137-150.

Sebastiá, M.T. (2004) Role of topography and soils in grassland structuring at the landscape and community scales. Basic and Applied Ecology, 5, 331-346.

Smith, R.S., Buckingham, H., Bullard, M.J., Shiel, R.S. \& Younger, A. (1996) The conservation management of mesotrophic (meadow) grassland in Northern England. I. Effects of grazing, cutting and fertiliser on the vegetation of a traditionally managed sward. Grass and Forage Science, 51, 278-291.

Söderström, B., Svensson, B., Vessby, K. \& Glimskär, A. (2001) Plants, insects and birds in seminatural pastures in relation to local habitat and landscape factors. Biodiversity and Conservation, $10,1839-1863$.

Tracy, B. \& Sanderson, M.A. (2000) Patterns of plant species richness in pasture lands of the northeast United States. Plant Ecology, 149, 169-180.

Tscharntke, T., Klein, A.-M., Kruess, A., Steffan-Dewenter, I. \& Thies, C. (2005) Landscape perspectives on agricultural intensification and biodiversity - ecosystem service management. Ecology Letters, 8, 857-874. 
WallisDeVries, M.F., Poschlod, P. \& Willems, J.H. (2002) Challenges for the conservation of calcareous grasslands in northwestern Europe: integrating the requirements of flora and fauna. Biological Conservation, 104, 265-273.

Wisskirchen, R. \& Haeupler, H. (1998) Standardliste der Farn- und Blütenpflanzen Deutschlands. Ulmer, Stuttgart, Germany. 


\section{CHAPTER}

Plant species richness and composition in managed grasslands: the relative importance of field management and environmental factors

Sebastian Klimek, Anne Richter gen. Kemmermann, Martina Hofmann \& Johannes Isselstein

In: Biological Conservation (in press) 


\begin{abstract}
Decline of grassland diversity throughout Europe within the last decades is threatening biological diversity and is a major conservation problem. There is an urgent need to determine the underlying factors that control vascular plant species richness and composition in managed grasslands. In this study, 117 grasslands were sampled using standardised methods. Explanatory variables were recorded for each grassland site, reflecting the local field management, site-specific environmental conditions and large-scale spatial trends. Using variation partitioning methods, we determined the pure and shared effects of these three sets of explanatory variables on the plant species richness and composition in grasslands. Most of the explained variation in plant species richness was related to the joint effect of local field management and environmental variables. However, the applied variation partitioning approach revealed that the pure effect of spatial variables contributed relatively little to explaining variation in both the plant species richness and species composition. The largest fractions of explained variation in plant species composition were accounted for by the pure effects of environmental and local field management variables. Moreover, the results revealed that the main mechanisms by which these sets of explanatory variables affect plant species vary according to the type of management regime under study. From our findings we could conclude that particularly a reduction of nitrogen fertilisation on meadows and grazing at a low stocking rate on pastures can help to conserve biodiversity.
\end{abstract}

Keywords: agri-environment schemes; species diversity; nitrogen fertilisation; grazing; variation partitioning 


\section{Introduction}

Conserving biodiversity and the services it provides is an urgent task for our society (Balmford et al., 2005). Grassland is an integral part of the semi-natural landscape of Central Europe and is of major importance for biodiversity in agricultural landscapes (WallisDeVries et al., 2002; Duelli and Obrist, 2003; Tscharntke et al., 2005).

In historic dimensions, traditionally managed grasslands have been extensively utilised by mowing and grazing and have hardly received artificial fertiliser (Garcia, 1992; Myklestad and Sætersdal, 2004). These semi-natural grasslands provided a wide range of habitats supporting a high biological diversity (Eriksson et al., 1995; Pärtel et al., 1999). But due to intensive grassland management along with high nutrient input and increased defoliation frequency on the one hand and the abandonment of marginal grassland on the other, grassland biodiversity has shown a dramatic decline over the last decades (Janssens et al., 1998; Hansson and Fogelfors, 2000; Kahmen et al., 2002).

Nowadays, species-rich grasslands can only be maintained if farmers receive compensation payments against intensification by means of agri-environment subsidies or if an intensification in management is not cost-effective (Hodgson et al., 2005). Up to now, a variety of agri-environment schemes have been applied in European countries to preserve and enhance biological diversity in agricultural systems (Kleijn and Sutherland, 2003), but their efficiency has been questioned (Kleijn et al., 2001). Recent studies have indicated that management agreements that include financial compensation for farmers are failing to prevent the process of diversity loss (Balmford et al., 2002; Ferraro and Kiss, 2002). In order to enhance the efficiency of management measures prescribed in agri-environment schemes, there is an urgent need to determine the underlying factors that control vascular plant species diversity in managed grasslands.

It has been well established that the maintenance of grassland communities in Western Europe depends on various kinds of repeated physical disturbance disfavouring shrubs and trees (Grace, 1999; Cousins and Eriksson, 2001). There is evidence that grassland management by grazing livestock at moderate levels contributes to the maintenance of plant diversity by reducing the abundance of competitive dominant species (Collins et al., 1998; Olff and Ritchie, 1998). In addition, grazing has been supposed to have a profound influence on small-scale grassland heterogeneity by creating disturbances in the soil and the sward structure, thereby enabling species establishment through niches (Olff and Ritchie, 1998; Adler et al., 2001). Several studies have furthermore shown that mowing at moderate cutting intensity maintained plant species richness in 
grasslands (Hansson and Fogelfors, 2000; Fischer and Wipf, 2002). For both management regimes, grazing as well as cutting, it has been well established that high nitrogen fertiliser applications generally decrease species diversity (Gough et al., 2000; Jacquemyn et al., 2003; Maurer et al., 2006).

Besides management regime and field management intensity, recent work showed that plant species richness varies in response to topography-related environmental factors such as site-specific solar radiation and slope angle (Pykälä et al., 2005; Bennie et al., 2006). Furthermore, Sebastiá (2004) found that soil fertility was the main environmental gradient structuring subalpine, calcareous grassland communities at the landscape scale. There is also evidence that on small spatial scales soil heterogeneity affects the distribution of plant species in grasslands (Reynolds et al., 1997) and that specific chemical soil characteristics are required to restore or maintain speciesrich grasslands (Janssens et al., 1998; Bakker and Berendse, 1999).

Although the effects of various above-mentioned factors on species diversity in grasslands have been analysed separately, the relative importance of field management and environmental variables remains largely unknown. Only a few studies analysed this relative importance directly (Vandvik and Birks, 2002; Myklestad, 2004). These studies did not take the spatial structuring of plant communities into account, which has been recognised as an important factor for spatial processes such as local dispersal (Borcard et al., 1992; Tuomisto et al., 2003; Svenning and Skov, 2005). In general, quantitative variation partitioning methods are widely used to investigate speciesenvironment relationships and to decompose the explained variation of dependent variables into independent components, thus differentiating between the relative importance of pure effects of different sets of explanatory variables and their joint effects (Økland and Eilertsen, 1994; Vandvik and Birks, 2002; Heikkinen et al., 2004; Myklestad, 2004). Although variation partitioning methods would not necessarily identify causal relationships, they would help to test hypotheses about the processes that may have generated the observed patterns (Borcard et al., 1992; Cushman and McGarigal, 2002).

The specific objectives of this study were: (i) to determine the relative importance of field management and environmental variables on plant species richness, (ii) to analyse the effects of the studied explanatory variables on plant species composition, and (iii) to examine if plant species richness and composition are affected differently with regard to their type of management regime (meadows, pastures and mowed pastures). 


\section{Materials and methods}

\section{The research area}

All field research was carried out within the rural district of Northeim in Lower Saxony (Germany), covering a total area of approximately $1260 \mathrm{~km}^{2}$ (Fig. 1). The average yearly precipitation in the research area is $645 \mathrm{~mm}$, with a mean annual temperature of $8.7^{\circ} \mathrm{C}$. The altitudes above sea level ranges from 72 to $527 \mathrm{~m}$. The research area is characterised by a large proportion of arable land and forest, interposed with patchily distributed fragments of grassland. Most of the agricultural grassland in the lowland areas is species-poor and structurally uniform, whereas in the steeper areas, fragments of species-rich semi-natural grassland can be found. The different grassland community types within the research area were investigated. These included mesic and intensive mown meadows and pastures on neutral to moderately acid soils (Arrhenatherion elatioris, Cynosurion), mown meadows on moist to wet soils (Calthion), limestone grasslands (Mesobromion erecti) and fragments of matgras swards (Nardion) on acid soils. Nomenclature of phytosociological units is according to Oberdorfer and Müller (1993).
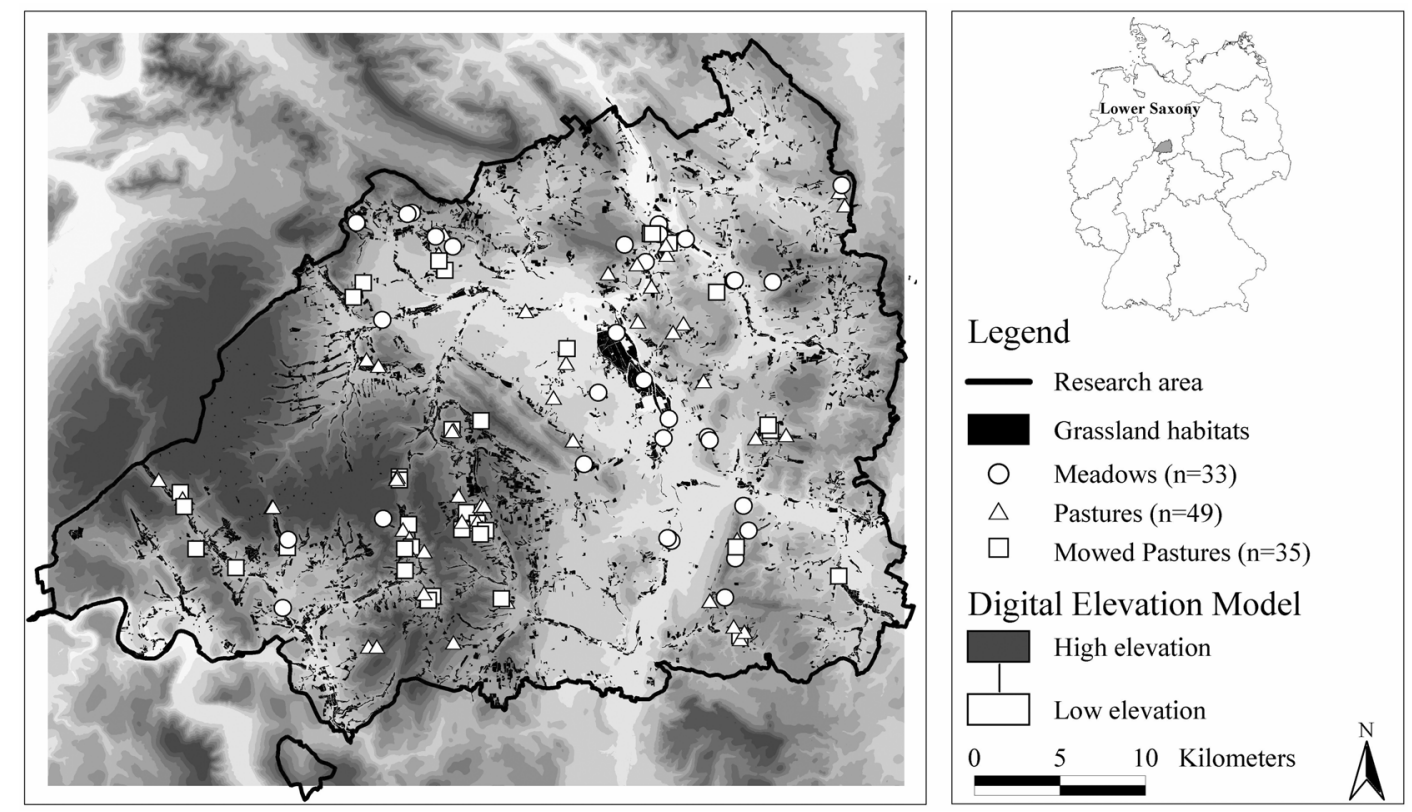

Fig. 1 Map of the research area in Lower Saxony, Germany, showing the sampled grassland sites $(\mathrm{n}=117)$ according to their type of management regime. 


\section{Sampling design and species data}

Grassland vegetation was recorded in two field surveys undertaken during May/June 2002 and 2004. We sampled a total of 117 managed grassland sites selected randomly, covering a complete gradient from agriculturally improved, species-poor grassland to semi-natural, species-rich grassland that had not experienced agricultural improvement. At each managed grassland site, three circular sample units of $12.6 \mathrm{~m}^{2}$ (radius $2 \mathrm{~m}$ ) each were established at a minimum distance of $10 \mathrm{~m}$ from each other for the assessment of vascular plant species richness and composition. Edge effects were avoided by excluding a 10-meter wide buffer zone from the field boundary. In each sample unit, all plant species were identified to species level. Species nomenclature followed that of Wisskirchen and Haeupler (1998).

The geographic position of each sample unit was recorded with a differential GPS and the grassland sites were digitalised by means of the geographic information system (GIS) ArcGIS (Version 8.3; ESRI Inc., Redlands, California). Information on current field size and shape was based on detailed digital cadastral data as well as high-resolution IR orthophotographs (taken on 3 June, 2002; pixel resolution $1 \mathrm{~m}$ ).

Following Whittaker (1977), we measured the number of plant species within each sample unit ('point diversity'). For each grassland site, the total number of plant species was determined by calculating the cumulative number of plant species that occurred in the three sample units. This measurement of plant species richness within each local grassland site corresponds to the measure of 'alpha diversity' as proposed by Whittaker (1977). However, bivariate linear correlation of the total number of species against the mean number of species of three sample units per grassland site revealed a highly significant relationship (Spearman rank correlation $r_{\mathrm{s}}=0.92, P<0.001$ ). Therefore, we restricted our analysis to the total number of species. As species richness is only one aspect of grassland biodiversity (Wilsey et al., 2005), species composition was considered in this study as well. To this end, the abundance of species in each grassland site was measured as the frequency of each species in the three sample units (Økland and Eilertsen, 1994).

\section{Explanatory variables}

To record the relevant information on management practices, the landowners of the investigated grassland sites were interviewed using a standardised questionnaire. The majority of the investigated sites was grazed without cutting (Pasture: 42\%). Fewer sites were cut only (Meadow: $28 \%$ ) or cut and grazed aftermath (Mowed Pasture: 30\%). The applied nitrogen (N) fertilisation per hectare and year included mineral $\mathrm{N}$, farmyard manure or liquid manure. The grazing intensity was 
estimated considering the type of grazing animal, stocking rates, timing and duration (Opitz von Boberfeld, 1994). The data on stocking rates were converted to standard livestock units (SLU) per hectare and year using a standard system based on a bovine weighing $500 \mathrm{~kg}$ (Allen, 1991). For meadows, cutting frequency was taken into account. The three quantitative explanatory variables, amount of nitrogen fertiliser applied, grazing intensity and cutting frequency, were used as a surrogate for field management intensity within the study. For the descriptive statistics of field management and environmental variables see Table 1.

In this study, the set of site-specific environmental variables was comprised of both topographyrelated environmental variables as well as soil-related ones. A high resolution digital elevation model (DEM) with a cell size of $12.5 \mathrm{~m}$ served as input for the representation of topography-related site conditions. This fine resolution has been recommended for the investigation of relationships between the physical aspects of a site and the species (Guisan et al., 1999). The following topography-related quantitative explanatory variables measured from all grassland sites using SAGA GIS Version 2.1 (available at http://www.saga-gis.org/) were included in the study: elevation, slope angle, sum of daily solar radiation and topographic wetness index. Solar radiation was calculated for each cell of the DEM as the daily sum of solar radiation at the beginning (15 April) of the growing period. The topographic wetness index was based on the equation given by Beven and Kirkby (1979). These topography-related explanatory variables were calculated for each grassland site by calculating the mean values. Additionally, the environmental variable soil quality, based on an estimate of the land's value for agricultural production, was spatially derived using detailed vector-based digital soil map data (Rothkegel, 1952). The area-weighted mean soil quality was determined for each grassland site.

Additionally, explanatory spatial variables were derived from the two-dimensional geographical coordinates (longitude and latitude) for each grassland site. Space was represented in this study by a cubic trend surface polynominal with nine variable terms (Borcard et al., 1992; Legendre and Legendre, 1998). To reduce the collinearity between the spatial variables of the sites, the trend surface variables were calculated from the centred longitude (X) and latitude (Y) (Legendre and Legendre, 1998; Svenning and Skov, 2005). The inclusion of a spatial component in the analysis allows for the testing of complex spatial trends in the dataset and accounts for the important role of spatial processes (Borcard et al., 1992). 
Table 1 Descriptive statistics of field management and environmental variables used in the analysis according to the type of management regime (Total: $n=117$; Meadows: $n=33$; Pastures: $n=49$; Mowed Pastures: $\mathrm{n}=35$ ).

\begin{tabular}{|c|c|c|c|c|}
\hline & Abbr. & Mean \pm SD & Minimum & Maximum \\
\hline \multicolumn{5}{|l|}{ Management variables } \\
\hline Nitrogen fertilisation $\left(\mathrm{kg} \mathrm{N} \mathrm{ha}^{-1}\right.$ year $\left.^{-1}\right)$ & $\mathrm{N}$ & & & \\
\hline Total & & $116.5 \pm 79.8$ & 0.0 & 321.6 \\
\hline Meadow & & $129.8 \pm 88.7$ & 0.0 & 321.6 \\
\hline Pasture & & $105.9 \pm 69.9$ & 12.2 & 255.1 \\
\hline Mowed Pasture & & $118.8 \pm 84.0$ & 7.7 & 286.4 \\
\hline Cutting frequency & CFR & & & \\
\hline Meadow & & $2.8 \pm 0.7$ & 1.0 & 4.0 \\
\hline Mowed Pasture & & $1.4 \pm 0.6$ & 1.0 & 3.0 \\
\hline Grazing intensity (SLU-days ha ${ }^{-1}$ year $\left.^{-1}\right)^{\S}$ & GRINT & & & \\
\hline Pasture & & $374.7 \pm 299.4$ & 58.8 & 1460.0 \\
\hline Mowed Pasture & & $159.2 \pm 124.7$ & 35.0 & 555.6 \\
\hline \multicolumn{5}{|l|}{ Environmental variables } \\
\hline Site-weighted mean soil quality ${ }^{\S \S}$ & SQ & & & \\
\hline Total & & $49.3 \pm 11.4$ & 25.0 & 82.0 \\
\hline Meadow & & $54.7 \pm 12.0$ & 32.0 & 74.0 \\
\hline Pasture & & $45.1 \pm 9.4$ & 25.0 & 72.0 \\
\hline Mowed Pasture & & $50.1 \pm 11.3$ & 30.0 & 82.0 \\
\hline Mean elevation (m a.s.1.) & ELEV & & & \\
\hline Total & & $216.4 \pm 65.2$ & 102.1 & 328.1 \\
\hline Meadow & & $177.7 \pm 65.7$ & 102.1 & 328.1 \\
\hline Pasture & & $233.8 \pm 58.7$ & 102.6 & 324.8 \\
\hline Mowed Pasture & & $228.4 \pm 59.4$ & 117.3 & 320.1 \\
\hline Mean slope angle (deg) & SLOPE & & & \\
\hline Total & & $7.6 \pm 4.7$ & 0.1 & 16.3 \\
\hline Meadow & & $4.7 \pm 3.8$ & 0.1 & 11.4 \\
\hline Pasture & & $9.7 \pm 4.4$ & 0.5 & 16.3 \\
\hline Mowed Pasture & & $7.2 \pm 4.5$ & 0.2 & 15.9 \\
\hline Mean solar radiation sum $\left(\mathrm{kWh} / \mathrm{m}^{2}\right)$ & RAD & & & \\
\hline Total & & $3.6 \pm 0.5$ & 2.1 & 4.7 \\
\hline Meadow & & $3.5 \pm 0.3$ & 2.8 & 4.3 \\
\hline Pasture & & $3.6 \pm 0.6$ & 2.1 & 4.7 \\
\hline Mowed Pasture & & $3.6 \pm 0.5$ & 2.7 & 4.5 \\
\hline
\end{tabular}

${ }^{\S}$ SLU-days ha $^{-1}$ year $^{-1}=$ Standard Livestock Units per hectare and year

${ }^{\S}$ Soil quality ranges from zero to one hundred; high values indicate a good soil quality for agricultural production and low values reflect poor soil quality. 


\section{Data analysis}

To assess the relative importance of field management, environmental and spatial variables on the vascular plant species richness and composition, statistical analyses were performed for the whole dataset (henceforth named total) and separately for the grassland sites grouped according to management regime. The environmental and spatial variables used in the models were identical for all four analyses, whereas the field management variables differed between the types of management regime under study. The type of management regime was included in the statistical analysis of the total dataset by three dummy variables. To test whether the mean values of plant species richness differed between the three types of management regime, we applied one-way ANOVA and Student-Newman-Keuls post-hoc tests (Fig. 2).

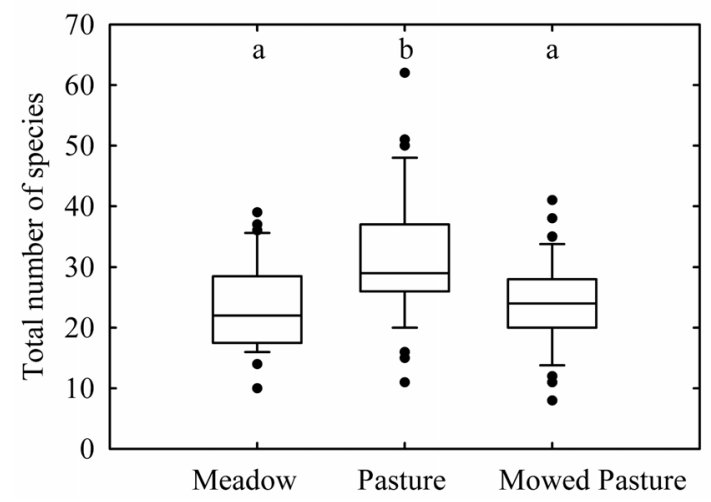

Fig. 2 Differences in the total number of species between three types of management regimes. The management regimes are: Meadows $(n=33)$, Pastures $(n=49)$ and Mowed Pastures $(n=35)$. The boxplots show median, interquartile range and outliers. The means of boxplots with different letters differ significantly from each other at $P<0.05$ (a posteriori SNK-test).

The variation partitioning approach was applied to determine both the pure and shared effects of field management, environmental and spatial variables on plant species richness and species composition (Borcard et al., 1992; Cushman and McGarigal, 2002; Heikkinen et al., 2004). As a first step, the total number of plant species in the grassland sites was related separately to each field management and environmental variable. The univariate analyses revealed linear relationships between species richness and the explanatory variables, so that quadratic terms were not included in further analyses. If necessary, logarithmic transformations of the variables were used prior to analyses to improve the linearity of relationships between dependent and explanatory variables. As 
collinearity within each set of explanatory variables can hamper the identification of effects (Lobo et al., 2002), we reduced each of the three sets of explanatory variables to a smaller number of independent factors using their correlation matrices based on Spearman rank correlations. In the case of highly correlated variables (Spearman rank correlation $r_{s}>0.7$ ), only one of them was used to avoid multicollinearity (Fielding and Haworth, 1995). Since the topographic wetness index was strongly correlated with slope angle in each dataset, the former variable was not used in subsequent analyses. The set of nine centred trend surface variables was also checked for multicollinearity and $\mathrm{X}, \mathrm{Y}, \mathrm{X}^{2}, \mathrm{XY}$ and $\mathrm{Y}^{2}$ were retained as explanatory trend surface variables in the spatial models.

For each species composition dataset, a detrended correspondence analysis (DCA; ter Braak and Smilauer, 2002) was performed on the log-transformed species abundance matrix with detrending by-segments and down-weighting of rare species. The largest gradient length, expressed in standard deviation (S.D.) units of species turnover, of the first four DCA axes were always below 2.2 S.D. units; thus, species showed a clearly linear response along the environmental gradient, making the use of linear-based ordination models appropriate for these data (ter Braak and Smilauer, 2002). Prior to DCA, those species occurring in less than five percent of the investigated grassland sites in the respective datasets were excluded from the analysis, because rare species may have an unduly large influence on such an analysis (ter Braak and Smilauer, 2002).

\section{Variation partitioning}

The variation in the total number of plant species and the plant species composition was decomposed into the three sets of explanatory variables, i.e. field management (M), environment (E) and space (S), using for each dataset a series of (partial) regression analyses with redundancy analysis (RDA), as implemented in the software package CANOCO (Version 4.5; ter Braak and Smilauer, 2002). Each set of explanatory variables was analysed separately using a manual forward stepwise procedure with associated Monte Carlo permutation tests $\left(10^{3}\right.$ permutations $)$ to obtain reduced subsets of variables best explaining the residual variation in each model (ter Braak and Smilauer, 2002; Heikkinen et al., 2004). Only variables significant at the $P<0.05$ level were included in the final models. Partial redundancy analyses were performed with all significant variables of each set to estimate the fraction of variation (measured as $\mathrm{R}^{2}$ ) of the dependent variable that can be attributed to one set of factors, by treating the variables of another set as covariables. To avoid an overestimation of the total variation explained, the number of explanatory variables within each set was comparable between analyses (Borcard et al., 1992; Økland and Eilertsen, 1994). Following the approach of Heikkinen et al. (2004), this method of variation partitioning enables the 
determination of the following eight different components: (M) pure effect of management variation

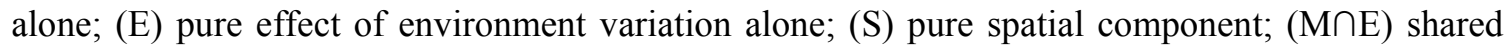
variation due to the joint effect of management and environment components; $(\mathrm{M} \cap \mathrm{S})$ shared

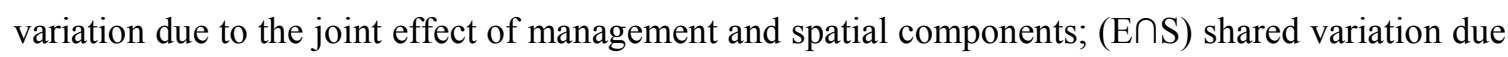
to the joint effect of environment and spatial components; $(\mathrm{M} \cap \mathrm{E} \cap \mathrm{S})$ shared variation due the joint effect of the three components, and finally variation not explained by the explanatory variables included in the analysis. The shared variation components are obtained by subtraction within the variation partitioning approach (Heikkinen et al., 2004) and could therefore not be tested for significance (Legendre and Legendre, 1998).

\section{Results}

\section{Comparison of different types of management regime}

Overall 243 plant species were sampled and identified in the total dataset, of which 188 were forb species and 55 were grasses. Within the management types meadows and mowed pastures, 121 (84 forbs and 37 grasses) and 125 (89 forbs and 36 grasses) plant species were recorded, respectively. In comparison, on the grassland sites managed by grazing alone, 205 plant species (162 forbs and 43 grasses) were identified. The species richness differed significantly between the types of management regime (Fig. 2). The grassland sites managed by grazing had significantly more species than those sites that were only mown or mown and grazed aftermath. However, no significant differences in species richness between meadows and mowed pastures could be detected.

\section{Partitioning the variation of species richness data}

Overall, most of the variation in plant species richness data was captured by the explanatory variables reflecting field management followed by the environmental site conditions and large-scale spatial trends (Table 2). The forward selection of explanatory variables revealed that plant species richness was negatively related to $\mathrm{N}$ fertilisation (Fig. 3a), while species richness in the grazed sites was significantly positively related to grazing intensity. Field management showed no significant relation to species richness in the sites that were cut and afterwards grazed. There was a trend towards lower species richness with increasing application of nitrogen fertilisation $(P=0.086)$. Within the meadows, only nitrogen fertilisation was significantly related to plant species richness $\left(\mathrm{R}^{2}=36.8 \%\right)$. 
Table 2 Importance of the explanatory variables in the RDA models for plant species richness according to management regime $($ Meadows $=\mathrm{M}$; Pastures $=\mathrm{P}$; Mowed Pastures $=\mathrm{MP}$ ). The amount of explained variation ( $\mathrm{R}^{2}$, equivalent to sum of all canonical eigenvalues, in \%) is given for each model. Directions of association $(-$ or +$)$ and $P$-levels for significant variables $(P<0.05)$ are shown (see Table 1 for abbreviations).

\begin{tabular}{|c|c|c|c|c|c|c|c|c|c|}
\hline & \multicolumn{3}{|c|}{ Management models } & \multicolumn{3}{|c|}{ Environmental models } & \multicolumn{3}{|c|}{ Spatial models } \\
\hline & Variable & $P$ & $\mathrm{R}^{2}$ & Variable & $P$ & $\mathrm{R}^{2}$ & Variable & $P$ & $\mathrm{R}^{2}$ \\
\hline Total & $\mathrm{N}$ & $0.001(-)$ & 30.7 & SQ & $0.001(-)$ & 26.5 & $\mathrm{X}^{2}$ & $0.017(-)$ & 5.2 \\
\hline & $\mathrm{P}$ & $0.001(+)$ & & SLOPE & $0.003(+)$ & & & & \\
\hline M & $\mathrm{N}$ & $0.001(-)$ & 36.8 & - & - & - & - & - & - \\
\hline $\mathrm{P}$ & $\begin{array}{l}\text { GRINT } \\
\mathrm{N}\end{array}$ & $\begin{array}{l}0.004(+) \\
0.010(-)\end{array}$ & 30.2 & SQ & 0.00 & 27.3 & - & - & - \\
\hline MP & - & - & - & SQ & $0.006(-)$ & 19.2 & $\mathrm{X}^{2}$ & $0.006(-)$ & 21.2 \\
\hline
\end{tabular}

The environment models showed a statistically significant decrease in plant species richness with higher soil quality (Fig. 3b). This relationship held true for the total dataset as well as for the pastures and mowed pastures. Grasslands which were only cut were not significantly related to either the environmental or spatial variables. The topography-related environmental variable slope angle showed a significant negative relation to plant species richness for the total dataset (Fig.3c). Only two of the four spatial models demonstrated a significant relation to large-scale spatial trends on species richness, expressed as a strong longitudinal gradient.
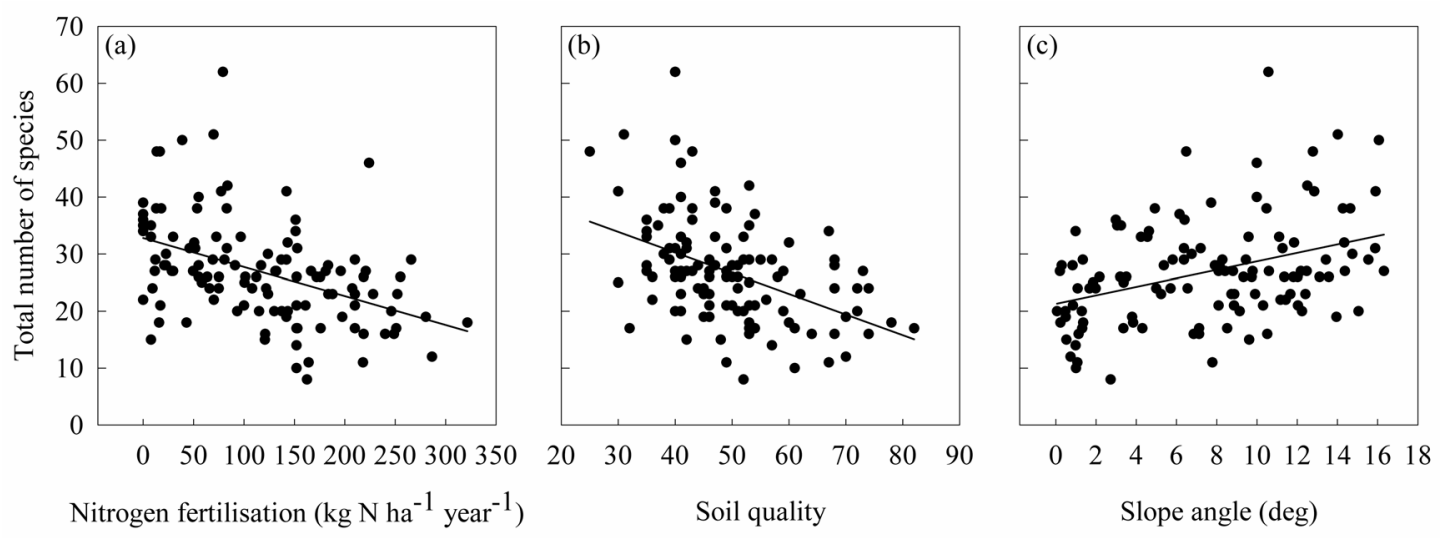

Fig. 3 The relationship between (a) total number of species and nitrogen fertilisation (b) total number of species and soil quality, and (c) total number of species and slope angle depicted as scatterplots with best-fit linear regression in each of the 117 managed grassland sites. 
Decomposing the explained variation in species richness datasets into variation components showed clear differences between models separated according to management regime (Table 3). In general, the variation partitioning approach revealed that most of the explained variation in the species richness of the total dataset and the pastures was related to the joint effect of field management and environmental variables (15.6\% and 15.3\%, respectively). The largest pure component was accounted for by field management variables, followed by environmental and spatial variables. Spatial variables showed a pure significant effect only for mowed pastures and a trend for the total dataset $(P=0.064)$. The amount of variation captured by all three sets of statistically significant explanatory variables was highest for pastures and for the total dataset ( $42.2 \%$ and $41.9 \%$, respectively).

\section{Partitioning the variation of species composition data}

The variation partitioning of the three species composition datasets for the management regimes resulted in relatively larger amounts of explained variation than for the total dataset, except for the meadow dataset (Table 3).

Table 3 Variance partitioning among the pure and combined effects of management (M), environment (E) and spatial (S) sets of explanatory variables explaining species richness and species composition in grasslands according to their type of management regime (Meadows $=\mathrm{M}$; Pastures $=\mathrm{P}$; Mowed Pastures $=\mathrm{MP})$. The fraction of variation explained $\left(\mathrm{R}^{2}\right.$, equivalent to sum of all canonical eigenvalues, in \%) is given for each component. $P$-levels for pure components as determined by Monte Carlo permutation tests $\left(\mathrm{n}=10^{3}\right)$ are given in brackets ( $\mathrm{ns}=$ not significant).

\begin{tabular}{|c|c|c|c|c|c|c|c|c|}
\hline & \multicolumn{3}{|c|}{ Pure components } & \multicolumn{4}{|c|}{ Shared components } & \multirow{2}{*}{ Unexplained } \\
\hline & $\mathrm{M}$ & $E$ & $\mathrm{~S}$ & $\mathrm{M} \cap \mathrm{E}$ & $\mathrm{M} \cap \mathrm{S}$ & $E \cap S$ & $\mathrm{M} \cap \mathrm{E} \cap \mathrm{S}$ & \\
\hline \multicolumn{9}{|c|}{ Species richness } \\
\hline Total & $12.0(0.001)$ & $9.1(0.001)$ & $1.8(\mathrm{~ns})$ & 15.6 & 1.6 & 0.3 & 1.5 & 58.1 \\
\hline M & $36.8(0.001)$ & - & - & - & - & - & - & 63.2 \\
\hline $\mathrm{P}$ & $14.9(0.010)$ & $12.0(0.003)$ & - & 15.3 & - & - & - & 57.8 \\
\hline MP & - & $16.0(0.008)$ & $18.0(0.008)$ & - & - & 3.2 & - & 62.8 \\
\hline \multicolumn{9}{|c|}{ Species composition } \\
\hline Total & $5.8(0.001)$ & $8.0(0.001)$ & $5.0(0.001)$ & 2.3 & 0.6 & 1.6 & 1.1 & 75.6 \\
\hline M & $10.5(0.001)$ & $9.6(0.001)$ & - & 2.3 & - & - & - & 77.6 \\
\hline $\mathrm{P}$ & $5.2(0.014)$ & $10.0(0.005)$ & $7.8(0.002)$ & 2.0 & 1.4 & 4.6 & -0.2 & 69.2 \\
\hline MP & $3.4(\mathrm{~ns})$ & $8.1(0.008)$ & $9.8(\mathrm{~ns})$ & 1.2 & 0.8 & 3.5 & 2.0 & 71.2 \\
\hline
\end{tabular}


The pure environment component of the total dataset included the statistically significant explanatory variables elevation, slope angle, solar radiation and soil quality (Table 4) and accounted for $8 \%$ of the explained variation in species composition after controlling for the effects of field management and large-scale spatial trends. Partitioning the variation in the total dataset revealed that $5.8 \%$ of the explained variation in species composition was solely attributable to field management variables. Pure spatial variation accounted for $5.0 \%$ of the explained variation. Shared variation components due to the joint effect of different sets of explanatory variables were generally of minor importance. The amount of explained variation in species composition of the total dataset captured by all statistically significant explanatory variables accounted for $24.4 \%$. The negative value of the shared variation component due the joint effect of the three components in the pasture dataset (-0.2\%) indicated that the corresponding explanatory variables of the three sets had opposite effects, i.e. one process was hindering the contribution of the other in the joint regression model (Legendre and Legendre, 1998).

Table 4 Importance of the explanatory variables in the RDA models for plant species composition according to management regime $($ Meadows $=\mathrm{M}$; Pastures $=\mathrm{P}$; Mowed Pastures $=\mathrm{MP})$. The amount of explained variation ( $\mathrm{R}^{2}$, equivalent to sum of all canonical eigenvalues, in \%) is given for each model. $P$-levels for significant variables $(P<0.05)$ are shown (see Table 1 for abbreviations).

\begin{tabular}{|c|c|c|c|c|c|c|c|c|c|}
\hline & \multicolumn{3}{|c|}{ Management models } & \multicolumn{3}{|c|}{ Environmental models } & \multicolumn{3}{|c|}{ Spatial models } \\
\hline & Variable & $P$ & $\mathrm{R}^{2}$ & Variable & $P$ & $\mathrm{R}^{2}$ & Variable & $P$ & $\mathrm{R}^{2}$ \\
\hline \multirow[t]{4}{*}{ Total } & $\mathrm{N}$ & 0.001 & 9.8 & ELEV & 0.001 & 13.0 & $\mathrm{X}$ & 0.001 & 8.3 \\
\hline & $\mathrm{M}$ & 0.001 & & SLOPE & 0.001 & & Y & 0.002 & \\
\hline & $\mathrm{P}$ & 0.017 & & RAD & 0.001 & & $\mathrm{X}^{2}$ & 0.004 & \\
\hline & & & & SQ & 0.012 & & $X Y$ & 0.021 & \\
\hline \multirow[t]{2}{*}{ M } & $\mathrm{N}$ & 0.001 & 12.8 & ELEV & 0.011 & 11.9 & - & - & - \\
\hline & & & & RAD & 0.011 & & & & \\
\hline \multirow[t]{4}{*}{$\mathrm{P}$} & $\mathrm{N}$ & 0.002 & 8.4 & ELEV & 0.001 & 16.4 & $\mathrm{Y}$ & 0.001 & 13.6 \\
\hline & GRINT & 0.014 & & SLOPE & 0.001 & & $\mathrm{XY}$ & 0.001 & \\
\hline & & & & RAD & 0.009 & & $\mathrm{X}$ & 0.033 & \\
\hline & & & & SQ & 0.025 & & & & \\
\hline \multirow[t]{3}{*}{ MP } & $\mathrm{N}$ & 0.003 & 7.5 & ELEV & 0.001 & 14.8 & $\mathrm{X}^{2}$ & 0.006 & 16.1 \\
\hline & & & & SLOPE & 0.012 & & Y & 0.008 & \\
\hline & & & & & & & $\mathrm{X}$ & 0.048 & \\
\hline
\end{tabular}


In Fig. 4, partial RDA biplots are shown to demonstrate the effects of pure field management and environment components on species composition in the total dataset. The partial RDA of the management component included the significant explanatory variable $\mathrm{N}$ fertilisation as well as two dummy variables representing the different types of management regime (Fig. 4a). Grassland sites with higher frequencies of Stellaria media, Роа апnиa and Poa trivialis were positively correlated with the amount of nitrogen fertiliser applied represented by partial RDA axis 1, whereas Ranunculus acris, Trifolium pratense and Rumex acetosa were negatively correlated to this factor (Fig. 4b). The partial RDA axis 1 of the pure environment component showed a gradient from grassland sites with a high soil quality to sites with higher slope angles (Fig. 4c). Sites with higher frequencies of Cardamine pratensis and Alopecurus pratensis were positively correlated with higher soil quality, whereas frequencies of Poa pratensis, Dactylis glomerata and Festuca pratensis increased on steeper sites (Fig. 4d). In this partial RDA, the second axis was determined mainly by solar radiation and elevation. Trifolium dubium and Poa angustifolia had a high score on the second axis and occurred on sites with either a lower elevation or a relatively high solar radiation. In comparison, Heracleum sphondylium and Agrostis capillaris occurred mainly on sites situated at higher elevations with low solar radiation. 

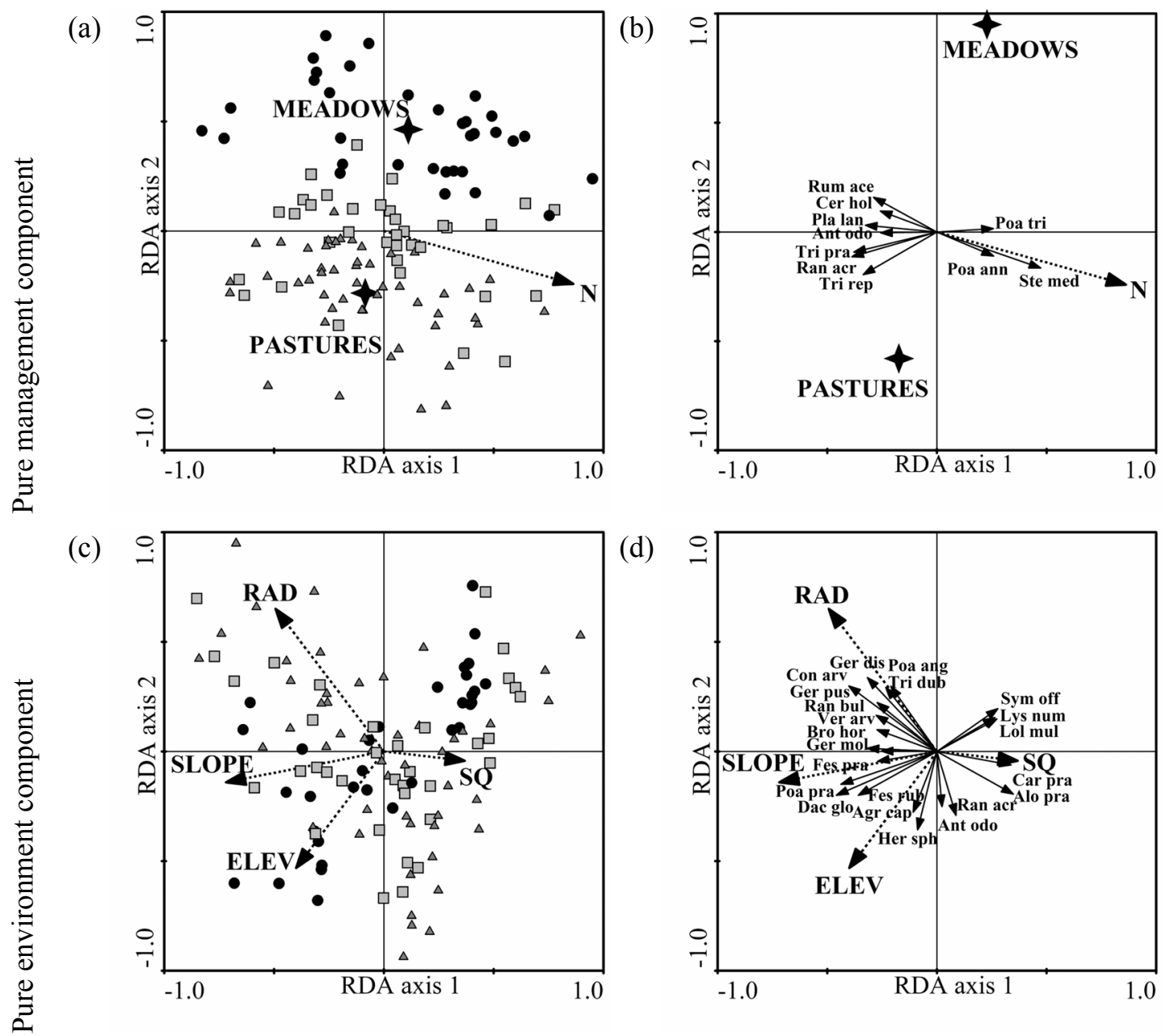

Fig. 4 Ordination biplots based on partial redundancy analysis (RDA axis 1 and 2) of the species composition data sampled in 117 grassland sites with different sets of explanatory variables (see Table 1 for abbreviations). Numeric explanatory variables are represented by dotted-line arrows, nominal explanatory variables by black stars and solid-line arrows are vascular plant species. Only species with scores $>0.25$ are shown for clarity. The types of management regime are shown with different symbols: Meadows by circles, Pastures by triangles and Mowed pastures by squares. Species codes: Agr cap $=$ Agrostis capillaris., Alo pra $=$ Alopecurus pratensis, Ant odo $=$ Anthoxanthum odoratum, Bro hor $=$ Bromus hordeaceus, Car pra $=$ Cardamine pratensis, Cer hol $=$ Cerastium holosteoides, Con arv $=$ Convolvulus arvensis, Dac glo $=$ Dactylis glomerata, Fes pra $=$ Festuca pratensis, Fes rub $=$ Festuca rubra, Ger dis $=$ Geranium dissectum, Ger $\mathrm{mol}=$ Geranium molle, Ger pus $=$ Geranium pusillum, Her $\mathrm{sph}=$ Heracleum sphondylium, Lol $\mathrm{mul}=$ Lolium multiflorum, Lys num = Lysimachia nummularia, Pla lan $=$ Plantago lanceolata, Poa ang $=$ Poa angustifolia, Poa ann $=$ Poa annua, Poa pra $=$ Poa pratensis, Poa tri $=$ Poa trivialis, Ran acr $=$ 
Ranunculus acris, Ran bul = Ranunculus bulbosus, Rum ace $=$ Rumex acetosa, Ste med $=$ Stellaria media, Sym off $=$ Symphytum officinale, Tri dub $=$ Trifolium dubium, Tri pra = Trifolium pratense, Tri rep $=$ Trifolium repens, Ver arv $=$ Veronica arvensis.

\section{Discussion}

\section{General effects of field management and environment on plant species in managed grasslands}

The decomposition of the explained variation in both the total number of species and the species composition into pure and shared variation components provided a comprehensive picture of the relative importance of field management, environmental site conditions and large-scale spatial trends in managed grasslands. The variation partitioning results suggest that the total amount of explained variation in both species richness and species composition could be enhanced by separating the total dataset according to the type of management regime and by including the field management variable grazing intensity in the respective statistical model. Thus, the local field management variable grazing intensity emerged as a crucial determinant for plant species in pastures and should not be ignored (Collins et al., 1998; Olff and Ritchie, 1998). Overall, we found strong pure effects of both field management and environmental variables on species richness and species composition. These findings support the view that plant species are most affected by local field management intensity and by environmental site conditions, both of which have been shown to be key factors in determining species diversity (Gough et al., 2000; Jacquemyn et al., 2003; Sebastiá, 2004; Pykälä et al., 2005; Bennie et al., 2006; Maurer et al., 2006). However, after partialling out the effects of management and environment, there was still a significant amount of variation in the species data that could be attributed to the pure effect of spatial variables. Thus, although the pure effect of spatial variables contributed relatively little to explaining the variation in plant species data, some variation in plant species data was not accounted for by the field management and environmental variables included in the analyses. This could be due to unmeasured, spatially correlated environmental variables (Borcard et al., 1992). Alternatively, Svenning and Skov (2005) suggested that in particular the purely spatial components probably reflect historical processes like large-scale dispersal limitation as seen in European-scale patterns in tree species composition and richness. Although dispersal is a spatial process (Tuomisto et al., 2003) most species inhabiting grasslands are not long lived in the seed bank and their dispersal among grasslands is limited in fragmented landscapes (Bakker and Berendse, 1999; Eriksson et al., 2002). 
In general, the results of the variation partitioning approach presented here revealed a relatively moderate amount of total explained variation in the plant species data. Furthermore, the results suggest that the relative amount of explained variation captured by all statistically significant explanatory variables is much higher for species richness data than for species composition data. On the one hand, this may be caused by the fact that the mechanisms controlling species composition in managed grasslands are more complex than those controlling species richness. These findings agree with statements of Ozinga et al. (2005) that species composition is more difficult to explain than species richness as this requires specific knowledge of the nature of the species. On the other hand, a large amount of unexplained variation, especially in species composition data, is a common finding in ordination models (Økland, 1999). Unexplained variation in species data may be caused by unmeasured non-spatial explanatory variables, or it can simply be attributed to a lack-of-fit of the data to the response model (Legendre and Legendre, 1998; Økland, 1999). Other potential explanations for the moderate amounts of explained variation in the species composition data by explanatory variables include missing small-scale environmental variables (Rosenzweig, 1997) as well as the degree of dispersal limitation of various species inherent in the data as suggested by Ozinga et al. (2005). Furthermore, the total explained variation could have been enhanced in this study by taking soil chemical variables into account which have been found to be important determinants of species composition in grasslands (Vandvik and Birks, 2002; Myklestad, 2004).

\section{Relative importance of explanatory variables on species richness}

Partitioning the explained variation in species richness datasets into field management, environmental site conditions and large-scale spatial trends revealed distinct differences between the total dataset and the three management regimes. Within the total dataset, species richness was positively related to slope angle and negatively related to soil quality. The high explanatory power of slope angle for species richness may be a result of the distribution of management regimes in the hilly study region where pastures were mostly located on relatively steep hillsides. Furthermore, the results indicate that soil quality accounted for a large amount of the explained variation in the species richness models, except for the meadows subset. The particular importance of soil characteristics as a main environmental determinant for structuring vegetation has also been demonstrated in subalpine grasslands at the landscape scale (Sebastiá, 2004). Notably, the partitioning of the explained variation in species richness datasets showed the shared variation due to the joint effect of management and environment components to be greater than the pure components, at least for the total dataset and for the pastures. In this study, the soil-related 
explanatory variable soil quality incorporated parameters describing the productiveness and fertility of agricultural land such as the soil type and the soil genesis (Rothkegel, 1952); therefore, it can be assumed that soil quality strongly interacted with field management intensity.

In general, the field management variables, including the amount of nitrogen fertilisation applied and grazing intensity, accounted for most of the explained variation in species richness. Since most plant species in grasslands are adapted to moderate or low nutrient conditions, these results agree with the findings of nutrient addition experiments in grasslands, which have demonstrated a general decrease in plant diversity in association with a high input of nitrogen fertilisers (Gough et al., 2000; Jacquemyn et al., 2003). Management practices such as grazing at a low stocking rate have been reported to be a key factor in maintaining species diversity in grasslands by reducing the abundance of competitive dominants and thereby indirectly favouring inferior species (Collins et al., 1998). We found a positive response of species richness to grazing intensity. It has been shown that plant species richness decreased with high grazing intensity in nutrient-poor ecosystems, while it increased with high grazing in nutrient-rich ecosystems (Proulx and Mazumber, 1998). Another potential explanation for the positive response of species richness to grazing intensity in the pasture subset may be due to the relatively moderate mean stocking rates. To sum up, our results suggest that field management intensity and soil quality were the primary determinants of vascular plant species richness in managed grasslands.

\section{Relative importance of explanatory variables on species composition}

The overall results of the variation partitioning approach highlight the importance of both field management and environmental site conditions as determinants of plant species composition in managed grasslands. In general, species composition is strongly dependent on the type of management regime and the associated management intensity (Eriksson et al., 1995; Kahmen et al., 2002; Jacquemyn et al., 2003). Our results showed species-specific responses to environmental variables. Slope angle and elevation were included in nearly all models, outlining the importance of locally extreme topographic site conditions on the occurrence of plant species (Pykälä et al., 2005; Bennie et al. 2006). The meadows were predominantly located at lower elevations in the study region and on less steep slopes than the pastures. Therefore, species composition in the meadows showed no significant response to slope angle. In the pastures, the pure environment component contributed much more of the explained variation in species composition than the pure field management component. The results probably reflect that topographic and soil-related site characteristics determined the spatial distribution of the management practices within the study 
region (White et al., 2004). Despite these environmental effects, the ordination biplot based on partial RDA demonstrated a relatively strong response of grassland species to nitrogen fertilisation and identified particular species adapted to either low or high nutrient levels. These species-specific responses to nitrogen fertilisation were confirmed by Ellenberg indicator values for nitrogen, which were designed to estimate the relationship between vascular plant species and the availability of nutrients in the soil (Ellenberg et al., 2001).

\section{Implications for conservation and grassland management}

The variation partitioning approach adopted in this study demonstrated a high analytical power of explicitly determining the relative importance of field management, environmental site conditions and spatial variables on plant species richness and composition in managed grasslands. Although the applied variation partitioning approach is correlational (Cushman and McGarigal, 2002), it yields explicit measures of the pure and shared effects of different sets of explanatory variables on dependent variables, thus enabling the determination of the possible underlying causal factors (Lobo et al., 2002).

Our results suggest to focus on both field management intensity and environmental site conditions in order to maintain and enhance botanical diversity in agricultural grasslands. Furthermore, the results revealed that conservation strategies should incorporate species richness as well as species composition to attain a more complete understanding of species diversity in grasslands. From our findings, we could conclude that economically unfavourable site characteristics, such as low soil quality and steep slopes are important determinants of plant species diversity. On more fertile soils, management practices like grazing may be needed to mitigate the negative effects of nutrient addition on species diversity. Therefore, particularly for nutrient-rich pastures the maintenance of grazing at a low stocking rate can effectively allow the conservation of a wide diversity of plant species. In this study, it became apparent that the amount of nitrogen fertiliser applied is a major determinant of plant species diversity in managed grasslands. For this reason, subsidies for farmers are necessary to compensate for any production losses associated with decreased management intensity. In this context, agri-environment schemes that aim to maintain and enhance biodiversity in grasslands should focus on management measures that take local site conditions into account. 


\section{Acknowledgements}

We are grateful to Elke Bertke for the permission to use part of her plant species data, Heike Culmsee for her comments on the statistics, Jürgen Böhner for help in handling the large grid datasets and Frederike de Mol for giving advice on managing vegetation databases. The authors also wish to thank T. Gatesman for correcting the English. Two anonymous referees and Rob Marrs made valuable comments on an earlier draft of this manuscript. This research is part of the BIOPLEX project (Biodiversity and spatial complexity in agricultural landscapes under global change) supported by the German Federal Ministry of Education and Research (BMBF). 


\section{References}

Adler, P.B., Raff, D.A., Lauenroth, W.K., 2001. The effect of grazing on the spatial heterogeneity of vegetation. Oecologia 128, 465-479.

Allen, V.G., 1991. Terminology for grazing lands and grazing animals. Pocahontas Press, Blacksbury, Virginia.

Balmford, A., Bruner, A., Cooper, P., Costanza, R., Farber, S., Green, R.E., Jenkins, M., Jefferiss, P., Jessamy, V., Madden, J., Munro, K., Myers, N., Naeem, S., Paavola, J., Rayment, M., Rosendo, S., Roughgarden, J., Trumper, K., Turner, R.K., 2002. Economic reasons for conserving wild nature. Science 297, 950-953.

Balmford, A., Bennun, L., Brink, B.T., Cooper, D., Côte, I.M., Crane, P., Dobson, A., Dudley, N., Dutton, I., Green, R.E., Gregory, R.D., Harrison, J., Kennedy, E.T., Kremen, C., LeaderWilliams, N., Lovejoy, T.E., Mace, G., May, R., Mayaux, P., Morling, P., Phillips, J., Redford, K., Ricketts, T.H., Rodriguez, J.P., Sanjayan, M., Schei, P.J., van Jaarsveld, A.S., Walther, B.A., 2005. The Convention on Biological Diversity's 2010 Target. Science 307, 212-213.

Bakker, J.P., Berendse, F., 1999. Constraints in the restoration of ecological diversity in grassland and heathland communities. Trends in Ecology and Evolution 14, 63-68.

Bennie, J., Hill, M.O., Baxter, R., Huntley, B., 2006. Influence of slope and aspect on long-term vegetation change in British chalk grasslands. Journal of Ecology 94, 355-368.

Beven, K.J., Kirkby, M.J., 1979. A physically based, variable contributing area model of basin hydrology. Hydrological Science Bulletin 24, 43-69.

Borcard, D., Legendre, P., Drapeau, P., 1992. Partialling out the spatial component of ecological variation. Ecology 73, 1045-1055.

Collins, S.L., Knapp, A.K., Briggs, J.M., Blair, J.M., Steinauer, E.M., 1998. Modulation of diversity by grazing and mowing in native tallgrass prairie. Science 280, 745-747.

Cousins, S.A.O., Eriksson, O., 2001. The occurrence of plant biodiversity in a hemiboreal landscape: the effects of habitat and history. Ecography 24, 461-469.

Cushman, S.A., McGarigal, K., 2002. Hierarchical, multi-scale decomposition of speciesenvironment relationships. Landscape Ecology 17, 637-646.

Duelli, P., Obrist, M.K., 2003. Regional biodiversity in an agricultural landscape: the contribution of seminatural habitat islands. Basic and Applied Ecology 4, 129-138.

Ellenberg, H., Weber, H.E., Düll, R., Wirth, V., Werner, W., 2001. Zeigerwerte von Pflanzen in Mitteleuropa. Scripta Geobotanica 18, 1-262. 
Eriksson, Å., Eriksson, O., Berglund, H., 1995. Species abundance patterns of plants in Swedish semi-natural pastures. Ecography 18, 310-317.

Eriksson, O., Cousins, S.O.A., Bruun, H.H., 2002. Land-use history and fragmentation of traditionally managed grasslands in Scandinavia. Journal of Vegetation Science 13, 743-748.

Ferraro, P.J., Kiss, A., 2002. Ecology - direct payments to conserve biodiversity. Science 298, 1718-1719.

Fielding, A.H., Haworth, P.F., 1995. Testing the generality of bird-habitat models. Conservation Biology 9, 1466-1481.

Fischer, M., Wipf, S., 2002. Effect of low-intensity grazing on the species-rich vegetation of traditionally mown subalpine meadows. Biological Conservation 104, 1-11.

Garcia, A., 1992. Conserving the species-rich meadows of Europe. Agriculture, Ecosystems and Environment 40, 219-232.

Gough, L., Osenberg, C.W., Gross, K.L., Collins, S.L., 2000. Fertilization effects on species density and primary productivity in herbaceous plant communities. Oikos 89, 428-439.

Grace, J.B., 1999. The factors controlling species density in herbaceous plant communities: an assessment. Perspectives in Plant Ecology Evolution and Systematics 2, 1-28.

Guisan, A., Weiss, S.B., Weiss, A.D., 1999. GLM versus CCA spatial modeling of plant species distribution. Plant Ecology 143, 107-122.

Hansson, M., Fogelfors, H., 2000. Management of a semi-natural grassland; results from a 15-yearold experiment in southern Sweden. Journal of Vegetation Science 11, 31-38.

Heikkinen, R.K., Luoto, M., Virkkala, R., Rainio, K., 2004. Effects of habitat cover, landscape structure and spatial variables on the abundance of birds in an agricultural-forest mosaic. Journal of Applied Ecology 41, 824-835.

Hodgson, J.G., Montserrat-Martí, G., Tallowin, J., Thompson, K., Díaz, S., Cabido, M., Grime, J.P, Wilson, P.J., Band, S.R., Bogard, A., Cabido, R., Cáceres, D., Castro-Díez, P., Ferrer, C. et al., 2005. How much will it cost to save grassland diversity? Biological Conservation 122, 263-273.

Jacquemyn, H., Brys, R., Hermy, M., 2003. Short-time effects of different management regimes on the response of calcareous grassland vegetation to increased nitrogen. Biological Conservation $111,137-147$.

Janssens, F., Peeters, A., Tallowin, J.R.B., Bakker, J.P., Bekker, R.M., Fillat, F., Oomes, M.J.M., 1998. Relationship between soil chemical factors and grassland diversity. Plant and Soil 202, 6978. 
Kahmen, S., Poschlod, P., Schreiber, K.F., 2002. Conservation management of calcareous grasslands. Changes in plant species composition and response of functional traits during 25 years. Biological Conservation 104, 319-328.

Kleijn, D., Berendse, F., Smit, R., Gilissen, N., 2001. Agri-environment schemes do not effectively protect biodiversity in Dutch agricultural landscapes. Nature 413, 723-725.

Kleijn, D., Sutherland, W.J., 2003. How effective are European agri-environment schemes in conserving and promoting biodiversity? Journal of Applied Ecology 40, 947-969.

Legendre, P., Legendre, L., 1998. Numerical Ecology, 2nd English Edition. Elsevier Science BV, Amsterdam.

Lobo, J.M., Lumaret, J.-P., Jay-Robert, P., 2002. Modelling the species richness distribution of French dung beetles (Coleoptera, Scarabaeidae) and delimiting the predictive capacity of different groups of explanatory variables. Global Ecology and Biogeography 11, 265-277.

Maurer, K., Weyand, A., Fischer, M., Stöcklin, J., 2006. Old cultural traditions, in addition to land use and topography, are shaping plant diversity of grasslands in the Alps. Biological Conservation 130, 438-446.

Myklestad, Å., 2004. Soil, site and management components of variation in species composition of agricultural grasslands in western Norway. Grass and Forage Science 59, 136-143.

Myklestad, A., Sætersdal, M., 2004. The importance of traditional meadow management techniques for conservation of vascular plant species richness in Norway. Biological Conservation 118, 133-139.

Oberdorfer, E., Müller, T., 1993. Süddeutsche Pflanzengesellschaften. Teil 3, Wirtschaftswiesen und Unkrautgesellschaften. Fischer, Jena, Germany.

Økland, R.H., Eilertsen, O., 1994. Canonical Correspondence Analysis with variation partitioning: some comments and an application. Journal of Vegetation Science 5, 117-126.

Økland, R.H., 1999. On the variation explained by ordination and constrained ordination axes. Journal of Vegetation Science 10, 131-136.

Olff, H., Ritchie, M.E., 1998. Effects of herbivores on grassland plant diversity. Trends in Ecology and Evolution 13, 261-265.

Opitz von Boberfeld, W., 1994. Grünlandlehre - biologische und ökologische Grundlagen. Ulmer, Stuttgart, Germany.

Ozinga, W.A., Schaminée, J.H.J., Bekker, R.M., Bonn, S., Poschlod, P., Tackenberg, O., Bakker, J., van Groenendael, J.M., 2005. Predictability of plant species composition from environmental conditions is constrained by dispersal limitation. Oikos 108, 555-561. 
Pärtel, M., Mändla, R., Zobel, M., 1999. Landscape history of a calcareous (alvar) grassland in Hanila, western Estonia during the last three hundred years. Landscape Ecology 14, 187-196.

Proulx, M., Mazumber, A., 1998. Reversal of grazing impact on plant species richness in nutrientpoor vs. nutrient-rich ecosystems. Ecology 79, 2581-2592.

Pykälä, J., Luoto, M., Heikkinen, R.K., Kontula, T., 2005. Plant species richness and persistence of rare plants in abandoned semi-natural grasslands in northern Europe. Basic and Applied Ecology 6, 25-33.

Reynolds, H.L., Hungate, B.A., Chapin III, F.S., D'Antonio, C.M., 1997. Soil heterogeneity and plant competition in an annual grassland. Ecology 78, 2076-2090.

Rosenzweig, M.L., 1997. Species diversity in space and time. Reprinted (with corr.), Cambridge University Press.

Rothkegel, W., 1952. Landwirtschaftliche Schätzungslehre. Ulmer, Stuttgart, Germany.

Sebastiá, M.T., 2004. Role of topography and soils in grassland structuring at the landscape and community scales. Basic and Applied Ecology 5, 331-346.

Svenning, J.-C., Skov, F., 2005. The relative roles of environment and history as controls of tree species composition and richness in Europe. Journal of Biogeography 32, 1019-1033.

ter Braak, C.J.F., Smilauer, P., 2002. CANOCO Reference manual and CanoDraw for Windows User's guide: Software for Canonical Community Ordination (version 4.5). Microcomputer Power (Ithaca, NY, USA).

Tscharntke, T., Klein, A.-M., Kruess, A., Steffan-Dewenter, I., Thies, C., 2005. Landscape perspectives on agricultural intensification and biodiversity - ecosystem service management. Ecology Letters 8, 857-874.

Tuomisto, H., Ruokolainen, K., Yli-Halla, M., 2003. Dispersal, environment, and floristic variation of western Amazonian forests. Science 299, 241-244.

Vandvik, V., Birks, H.J.B., 2002. Partitioning floristic variance in Norwegian upland grasslands into within-site and between-site components: are the patterns determined by environment or by land-use? Plant Ecology 162, 233-245.

WallisDeVries, M.F., Poschlod, P., Willems, J.H., 2002. Challenges for the conservation of calcareous grasslands in northwestern Europe: integrating the requirements of flora and fauna. Biological Conservation 104, 265-273.

White T.A., Barker, D.J., Kenneth, J.M., 2004. Vegetation diversity, growth, quality and decomposition in managed grasslands. Agriculture, Ecosystems and Environment 101, 73-84. 
Whittaker, R. H., 1977. Evolution of species diversity in land communities. Evolutionary Biology 10, 1-67.

Wilsey, B.J., Chalcraft, D.R., Bowles, C.M., Willig, M.R., 2005. Relationships among indices suggest that richness is an incomplete surrogate for grassland biodiversity. Ecology 86, 11781184.

Wisskirchen, R., Haeupler, H., 1998. Standardliste der Farn- und Blütenpflanzen Deutschlands. Ulmer, Stuttgart, Germany. 


\section{CHAPTER}

Opposing effects of local and landscape factors on plant species richness in mown vs. grazed grassland 


\section{Summary}

1. Intensification of agricultural land-use practices along with the fragmentation of semi-natural habitats caused a dramatic decline of species diversity at the local and landscape scales. The purpose of this study was to test whether plant species richness of mown or grazed grassland responds differently to local and landscape factors.

2. We examined the relative importance of local topographic, management and landscape variables for plant species richness of 30 mown meadows and 30 grazed pastures, considering landscape structure variables at two different spatial scales $(250 \mathrm{~m}$ and $500 \mathrm{~m})$. Using variation partitioning and hierarchical partitioning in a complementary manner, we determined the independent and joint effects of local and landscape factors on plant species richness of both management regimes.

3. The partitioning approaches revealed contrasting responses of plant species richness to local and landscape factors depending on the management regime. While plant species richness of meadows was solely determined by a negative effect of nitrogen fertilisation, plant species richness of pastures was affected by both local and landscape factors. Thus, in pastures, local site conditions such as steep slopes and low soil quality were positively related to plant species richness. Grazing at moderate stocking rates also contributed to high plant species richness.

4. Our results indicated an opposing effect between management regime and landscape context. Plant species richness of meadows was not affected by landscape context whereas plant species richness of pastures significantly decreased with increasing percentage of arable land in the surrounding landscape.

5. Synthesis and applications. Our results demonstrate that low to moderate intensity livestock grazing enhances plant species richness in managed grasslands. Securing coherent areas of extensively managed pastures at the landscape level by means of agri-environment schemes could combine biodiversity improvements with reduced costs for pasture management to the farmer.

Key-words: agri-environment schemes, biodiversity, conservation, grassland management, hierarchical partitioning, landscape structure, variance partitioning 


\section{Introduction}

Over the last decades, both the decrease of the area and the fragmentation of semi-natural habitats caused a dramatic decline of biodiversity at local, regional and global scales (Critchley, Burke \& Stevens 2004; Krauss et al. 2004; Balmford et al. 2005). These processes have been largely attributed to the intensification of land-use practices along with agricultural expansion (Hodgson et al. 2005b; Tscharntke et al. 2005; Donald \& Evans 2006). More recently, these pressures of agricultural intensification have increased by abandonment of many low-productivity semi-natural grasslands that no longer ensured sufficient economic yields (Critchley, Burke \& Stevens 2004; Hodgson et al. 2005a). At the field scale, management intensification resulted in simplified, species-poor grassland communities of low nature conservation value, mainly due to high nutrient input and increased defoliation frequency (Janssens et al. 1998; Rook et al. 2004). At the landscape scale, management intensification has been supposed to have profound influence by creating relatively simple and homogeneous landscapes dominated by arable fields (Jongman 2002; Tscharntke et al. 2005).

Grassland management regime (Bakker 1989; Kahmen, Poschlod \& Schreiber 2002; Jacquemyn, Brys \& Hermy 2003), abiotic site conditions including climate, soil properties, and topographyrelated physical attributes (Janssens et al.1998; Pykälä et al. 2005b; Bennie et al. 2006), and biotic interactions (Grime 2001; Lepš 2005) are important factors determining local plant species richness in grasslands. Semi-natural grassland in Western Europe depends on various kinds of repeated physical disturbance, caused e.g. by grazing animals or mowing, in order to maintain plant species richness (Grace 1999; Cousins, Lavorel \& Davies 2003). Lack of such management favours shrubs and trees and thus leads to species-loss on the long term (Grace 1999). Recent studies have suggested that grazing livestock at moderate densities can increase plant diversity by reducing the abundance of dominant species (McIntyre, Lavorel \& Tremont 1995; Collins et al. 1998; Olff \& Ritchie 1998; Collins, Glenn \& Briggs 2002). At moderate livestock grazing pressure, animals furthermore disturb the soil and sward structure through selective grazing, trampling and deposition of excreta, thereby favouring colonisation with plants due to small-scale disturbances (Adler, Raff \& Lauenroth 2001; Bullock et al. 2001; Rook et al. 2004). In addition, grazing animals may affect grassland vegetation by acting as dispersal agents (Rook et al. 2004). Mowing also affects grassland vegetation. Beneficial effects on floristic diversity have been associated with mowing once a year in August along with removal of hay crop (Kahmen, Poschlod \& Schreiber 2002). For both management regimes, grazing as well as cutting, it has been demonstrated that plant diversity 
generally decreases with high nitrogen fertiliser applications since most grassland communities are adapted to low nutrient conditions (Gough et al. 2000; Jacquemyn, Brys \& Hermy 2003).

Most ecological processes causing variation in local species richness operate simultaneously at different spatial scales (Whittaker, Willis \& Field 2001; Collins, Glenn \& Briggs 2002; Olff \& Ritchie 2002). Nevertheless, the potential importance of landscape variables at different spatial scales for plant species has still received limited attention (de Blois, Domon \& Bourchard 2002). Recent studies in agricultural landscapes have demonstrated a relationship between local species richness and the surrounding landscape at species-specific spatial scales mainly for organisms with high-dispersal abilities, whereas local species richness of plants was mostly not affected by landscape variables (Steffan-Dewenter et al. 2002; Dauber et al. 2003; Weibull, Östman \& Granqvist 2003; Krauss et al. 2004; Tscharntke et al. 2005). There is, however, some evidence for a negative impact of a large amount of arable land in the surrounding landscape on local plant species richness, as demonstrated in agricultural landscapes for vascular plants in pastures (Söderström et al. 2001) and for arable weeds (Roschewitz et al. 2005).

The primary focus of this study was to test responses of plant species richness of mown meadows and grazed pastures to local and landscape factors. The contrasting grassland management regimes provide the opportunity to explicitly compare the relative importance of these factors on plant species richness. The ability to disperse and to colonise habitats differs between plant strategy types (Grime 2001; Geertsema, Opdam \& Kropff 2002; Cousins, Lavorel \& Davies 2003; Krauss et al. 2004). Moreover, there is evidence that dispersal into a grassland habitat depends on the species pool at a higher spatial scale (Pärtel et al. 1996; Lepš 2005). As studies concerning the effect of landscape context on local plant species are rare, and dispersal strategies vary between plant strategy types, we related plant species richness to landscape structure variables at two spatial scales that proved ecologically relevant (Söderström et al. 2001; Roschewitz et al. 2005; Tscharntke et al. 2005).

Our objectives were thus to compare the relative importance of local and landscape factors on plant species richness in mown meadows and grazed grasslands, and to test whether plant species richness of contrasting management regimes is related to landscape structure at different spatial scales $(250 \mathrm{~m}$ and $500 \mathrm{~m}$ ). We hypothesised that (i) the relative importance of nitrogen fertiliser input was more important for meadows than for pastures as nutrient addition is suggested to cause more competitive exclusion in grasslands protected from herbivory (Gough \& Grace 1998), and (ii) the relative importance of landscape structure variables on local plant species richness should be more pronounced for pastures than for meadows, as grazing at moderate levels should facilitate 
species colonisation from the surrounding landscape. In order to test these hypotheses, we used variation partitioning and hierarchical partitioning, which are novel statistical approaches that provide deeper understanding of the relative importance of different sets of explanatory variables for biodiversity patterns (Heikkinen et al. 2005).

\section{Materials and methods}

\section{Study area and parcel selection}

The study area covered an area of $c .1260 \mathrm{~km}^{2}$ (approximate north-south boundaries $51^{\circ} 95^{\prime} \mathrm{N}$ to $51^{\circ} 61^{\prime} \mathrm{N}$ ) and was situated in the southern part of Lower Saxony, Germany (administrative district of Northeim). The mean annual temperature was $8.7^{\circ} \mathrm{C}$, and the annual precipitation averaged 645 $\mathrm{mm}$. The relief gradient was rather high, with altitudes above sea level ranging from $72 \mathrm{~m}$ in the lowlands to $527 \mathrm{~m}$ in the wooded hillsides of the western part of the study area. The study area was dominated by agricultural land use, covering $c .38 \%$ of the region, and large contiguous forestcovered areas in the hilly regions. Within the agricultural landscape, patchily distributed fragments of agriculturally improved, species-poor grassland were mainly located in the lowland areas (Fig. 1). Semi-natural, species-rich grassland that had not experienced any agricultural improvement were predominantly situated in the steeper areas
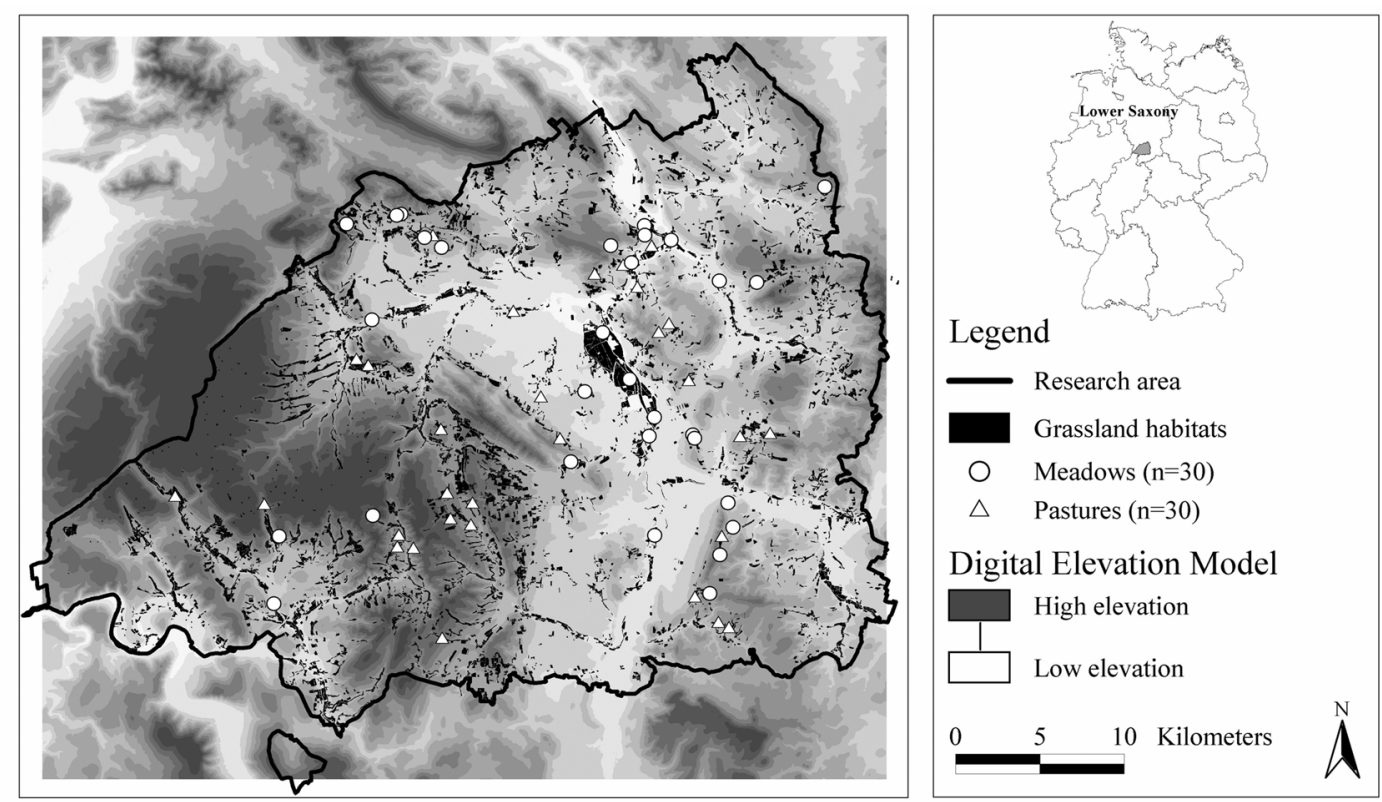

Fig. 1 Map of the study area in Lower Saxony, Germany, showing the location of the sampled grassland parcels $(n=60)$ according to their type of management regime. 
In this study, a total of 60 managed grassland parcels belonging to 30 different farms were sampled. Floristic surveys were carried out at 30 meadows that were cut only and 30 grazed pastures without any cutting treatment. Parcel selection criteria included consideration of characteristic agricultural management practices in close collaboration with local farmers and spatial independence with respect to geographical distances between the study parcels.

Unfertilised meadows were usually cut once late in the year, while fertilised meadows were cut two to four times a year. The investigated pastures were all fertilised with mineral $\mathrm{N}$, farmyard manure or liquid manure. Grazing intensity by growing cattle or sheep varied between and within farms depending on the distance to the farm centre and the topographic conditions of the parcel. Pastures were mainly utilized by rotational grazing at a low to moderate intensity. The grazing season started in May and ended between September and November.

\section{Species sampling}

All field research was carried out during two surveys in May/June 2002 and 2004. In each grassland parcel, we sampled three circular vegetation plots of $12.6 \mathrm{~m}^{2}$ (radius $2 \mathrm{~m}$ ) at a distance of $10 \mathrm{~m}$ from each other for the assessment of vascular plant species richness. Edge effects were avoided by excluding a 10-meter buffer zone from the parcel boundary. The geographic position of each vegetation plot was recorded with differential GPS and the parcels were digitalised by means of the geographic information system (GIS) ArcGIS (Version 8.3; ESRI Inc., Redlands, California). The grassland parcel shape and size was determined using current digital land parcel maps based on the official Land Parcel Information System of Lower Saxony (LPIS) as well as high-resolution IR orthophotographs (taken on 3 June, 2002; pixel resolution $1 \mathrm{~m}$ ).

In each circular vegetation plot, a complete floristic survey was carried out before the first cut or the beginning of grazing by livestock, respectively. All vascular plant species were identified to species level and the species numbers were summed to total number of species per parcel. Species nomenclature followed that of Wisskirchen and Haeupler (1998).

\section{Local habitat variables}

In this study, two groups of explanatory variables were recorded for each grassland parcel: (i) local topographic and (ii) local field management variables. For information on abiotic site conditions, we used a high resolution digital elevation model (DEM) with a cell size of $12.5 \mathrm{~m}$ and soil data from vector-based soil maps (scale 1:5.000). Based on the DEM, we calculated elevation and slope (inclination in ${ }^{\circ}$ ) as well as the solar radiation at the beginning (15 April) of the growing period. 
Solar radiation was calculated for each cell of the DEM as the daily sum of solar radiation $\left(\mathrm{kWh} \mathrm{m}^{-}\right.$ $\left.{ }^{2}\right)$ that reaches a position on the earth surface assuming a constant for atmospheric transmittance of $60 \%$. Furthermore, we derived a topographic wetness index that provides relative estimates of soil moisture conditions based on slope and catchment area. The calculation of the topographic wetness index was based on the equation given by Beven and Kirkby (1979). However, as the topographic wetness index was strongly correlated with the slope (Spearman rank correlation coefficient $r_{s}>0.6$ for both the meadow and the pasture datasets), it was not used in further analyses. The topographyrelated explanatory variables were calculated for each grassland parcel by calculating the mean values using SAGA GIS Version 2.1 (available at http://www.saga-gis.org/). Additionally, the environmental variable soil quality, based on digital soil evaluation data, was spatially derived using vector-based digital soil maps. The explanatory variable soil quality incorporates parameters describing the productiveness and fertility of agricultural land such as soil type and soil genesis (Rothkegel 1952). The area-weighted mean soil quality was determined for each grassland parcel.

To record relevant information about local field management intensity, all involved farmers were interviewed using a standardised questionnaire. The meadows were mostly fertilised with mineral nitrogen applications $\left(\mathrm{kg} \mathrm{N} \mathrm{ha}^{-1}\right.$ year $\left.^{-1}\right)$ between the cuts while the applied nitrogen fertilisation for the pastures included mineral N, farmyard manure or liquid manure. The cutting frequency of the meadows was not taken into account, because it was highly correlated with the applied nitrogen fertilisation and thus redundant (Spearman rank correlation coefficient $r_{s}>0.6$ ). Grazing intensity was estimated considering the type of grazing animal, stocking rates, timing and duration (Opitz von Boberfeld 1994). The data on stocking rates were converted to standard livestock units (SLU) per hectare and year using a standard bovine weighing $500 \mathrm{~kg}$ (Allen 1991). The descriptive statistics (means $\pm \mathrm{SD}$ ) of the explanatory variables are given in Table 1 . 
Table 1 Descriptive statistics (means \pm SD) of vascular plant species richness, local topographic, field management and landscape variables used in the analyses (Meadow: $n=30$; Pasture: $n=30$ ). Comparisons of the mean values were conducted using nonparametric Mann-Whitney U-tests. The means of variables with different letters differ significantly from each other at $P<0.05$.

\begin{tabular}{|c|c|c|c|}
\hline & Abbr. & Meadow & Pasture \\
\hline Species richness & & $23.8 \pm 7.1 \mathrm{a}$ & $31.1 \pm 10.0 \mathrm{~b}$ \\
\hline \multicolumn{4}{|l|}{ Local topographic variables } \\
\hline Mean elevation (m a.s.1.) & ELEV & $183.8 \pm 65.8 \mathrm{a}$ & $228.0 \pm 55.7 \mathrm{~b}$ \\
\hline Mean slope (inclination in deg) & SLOPE & $5.1 \pm 3.8 \mathrm{a}$ & $10.7 \pm 4.4 \mathrm{~b}$ \\
\hline Mean solar radiation $\left(\mathrm{kWh} \mathrm{m}^{-2}\right)$ & $\mathrm{RAD}$ & $3.5 \pm 0.3 \mathrm{a}$ & $3.7 \pm 0.6 \mathrm{a}$ \\
\hline Mean soil quality ${ }^{*}$ & SQ & $54.1 \pm 12.3 \mathrm{a}$ & $44.9 \pm 8.3 b$ \\
\hline \multicolumn{4}{|l|}{ Local management variables } \\
\hline Nitrogen fertilisation $\left(\mathrm{kg} \mathrm{N} \mathrm{ha}^{-1}\right.$ year $\left.^{-1}\right)$ & $\mathrm{N}$ & $132.0 \pm 90.8 \mathrm{a}$ & $93.0 \pm 63.6 \mathrm{a}$ \\
\hline Grazing intensity (SLU-days $\mathrm{ha}^{-1}$ year $\left.^{-1}\right)^{\dagger}$ & GRINT & & $360.5 \pm 257.2$ \\
\hline \multicolumn{4}{|l|}{ Landscape structure variables } \\
\hline Scale $250 \mathrm{~m}$ : Percentage of arable land & PA_250 & $29.3 \pm 22.3 \mathrm{a}$ & $37.3 \pm 21.3 \mathrm{a}$ \\
\hline Scale $500 \mathrm{~m}$ : Percentage of arable land & PA_500 & $32.7 \pm 22.8 \mathrm{a}$ & $38.6 \pm 18.6 \mathrm{a}$ \\
\hline Scale $250 \mathrm{~m}$ : Percentage of grassland & PG_250 & $23.1 \pm 20.4 \mathrm{a}$ & $24.2 \pm 14.1 \mathrm{a}$ \\
\hline Scale $500 \mathrm{~m}$ : Percentage of grassland & PG_500 & $19.1 \pm 17.4 \mathrm{a}$ & $18.1 \pm 9.4 \mathrm{a}$ \\
\hline Scale $250 \mathrm{~m}$ : Habitat-type diversity & SHDI_250 & $1.2 \pm 0.3 \mathrm{a}$ & $1.2 \pm 0.2 \mathrm{a}$ \\
\hline Scale $500 \mathrm{~m}$ : Habitat-type diversity & SHDI_500 & $1.2 \pm 0.3 \mathrm{a}$ & $1.3 \pm 0.2 \mathrm{a}$ \\
\hline
\end{tabular}

*Soil quality ranges from zero to one hundred; high values indicate a high soil quality for agricultural production and low values reflect poor soil quality.

${ }^{\dagger}$ SLU-days ha $^{-1}$ year $^{-1}=$ Standard Livestock Unit days per hectare and year

${ }^{\dagger}$ Habitat-type diversity is measured using Shannon's diversity index

\section{Landscape analysis}

The habitat surrounding each grassland parcel was quantified by generating buffers of $250 \mathrm{~m}$ and $500 \mathrm{~m}$ around the parcel boundaries, which represented a nested set of spatial scales. The choice of the spatial scales of the buffers was based on publications testing the relationship between local plant species richness and the surrounding landscape (Söderström et al. 2001; Dauber et al. 2003; Roschewitz el al. 2005; Tscharntke et al. 2005). Official digital vector-based maps (ATKIS Digitales Landschaftsmodell 25/1; Landesvermessung und Geobasisinformation Niedersachsen, Hannover, Germany, 1991-1996) were used to determine the area of arable land, permanent grassland, forests, settlements, hedgerows, water bodies and gardens. Since profound land use changes took place over the past decade along with the replacement of both improved and semi- 
natural grasslands by arable fields, we enhanced the actuality of the ATKIS data by integrating actual vector-based data on the distribution of arable land and permanent grassland using current digital land parcel maps. To avoid testing uninformative hypotheses (Anderson, Burnham \& Thompson 2000) of correlated variables and to ensure ecological relevance (Li \& Wu 2004), we only selected those variables connected to our hypotheses and those likely to affect vascular plant species richness. The digital categorical land use map was converted to a raster data model (cell size $10 \mathrm{~m}$ ) and three landscape structure variables were calculated for each $250 \mathrm{~m}$ and $500 \mathrm{~m}$ buffer: percentage of arable land, percentage of permanent grassland and landscape heterogeneity (measured as habitat diversity using Shannon's diversity index). The percentage of arable land and permanent grassland surrounding each grassland parcel was used as a surrogate for structural connectivity in fragmented landscapes (Moilanen \& Nieminen 2002). Landscape structure variables were not related to each other for either the meadow or the pasture dataset at the two spatial scales studied (Spearman rank correlation coefficient $r_{s}<0.5$ ). The intersection and updating of land use data was conducted using ArcInfo GIS (Version 8.3; ESRI Inc., Redlands, California) and the calculations of landscape structure (metric) variables were performed using the raster version of FRAGSTATS (Version 3.3; McGarigal et al. 2002).

\section{Statistical analysis}

The relative importance of local topographic, management and landscape variables on species richness of meadows and pastures was tested simultaneously considering landscape structure variables at two different spatial scales. To test whether the mean values of species richness and explanatory variables differed between meadows and pastures, we applied non-parametric MannWhitney U tests. We employed two main methods to test whether the number of plant species was more strongly controlled by forces acting at the local or at the landscape scale: variation partitioning and hierarchical partitioning. Both types of analyses were performed separately for the meadow dataset and the pasture dataset as well as for both spatial scales investigated.

To quantify the species-environment relationships, we used variation partitioning to decompose the variation in species richness of meadows and pastures into three groups of explanatory variables: local topography $(\mathrm{T})$, local management $(\mathrm{M})$ and landscape structure $(\mathrm{L})$ variables. The procedure of variation partitioning was replicated for each of the two investigated spatial scales. To determine the pure and combined effects of the three sets of explanatory variables on species richness, we used for each dataset a series of (partial) regression analyses with redundancy analysis (RDA) to isolate all variation components (Heikkinen et al. 2004) using the software package 
CANOCO (Version 4.5; ter Braak and Smilauer 2002). Each set of explanatory variables was analysed separately using a manual forward selection procedure of explanatory variables to obtain reduced subsets of variables that best explained the residual variation in species richness (Borcard, Legendre \& Drapeau 1992). According to Økland and Eilertsen (1994), the elimination of variables that do not contribute significantly to the explanation of the variation in species richness gives a more realistic picture of the variation explained. The statistical significance of the explanatory effect on species richness was tested for each dataset by use of the Monte Carlo permutation test ( $10^{3}$ permutations). Only explanatory variables significant at the $P<0.1$ level (Benjamin, Domon \& Bouchard 2005) were included in the final models. Following Cottenie et al. (2003), we did not adjust the $P$-values for multiple testing.

Partial regression analyses by means of RDA were performed for all significant variables of each set to estimate the fraction of variation of the response variable that can be attributed to one set of factors, by treating the variables of another set as covariables (ter Braak 1995; Cushman \& McGarigal 2002). Following the approach of Heikkinen et al. (2004) and Liu (1997), the method of variance partitioning enabled the determination of the following eight components: A) pure effect of local topography; B) pure effect of local field management; C) pure effect of landscape structure; D) combined effect of topography and management; E) combined effect of topography and landscape structure; F) combined effect of management and landscape structure; G) combined effect of all three groups of explanatory variables; and $\mathrm{H}$ ) unexplained variation (Fig. 2). To evaluate the statistical significance of the pure effects, we used Monte Carlo permutation tests (with $10^{3}$ permutations). The combined effects were obtained by subtraction (Liu 1997; Heikkinen et al. 2004) and could therefore not be tested for significance (Legendre \& Legendre 1998).

To identify the explanatory variables most likely to effect the variation in plant species richness of meadows and pastures, we applied hierarchical partitioning. The hierarchical partitioning provided an estimate of the independent effect of a particular explanatory variable by computing the increase in the fit (measured as $\mathrm{R}^{2}$ within the framework of this study) of all models with this particular explanatory variable compared to the equivalent model without that variable, and averaging the improvement of the fit across all possible models in which this explanatory variable occurs (Mac Nally 2000, 2002; Heikkinen et al. 2004, 2005). As a result, for each explanatory variable, the explanatory power is segregated into independent effects and effects caused jointly with other explanatory variables (Chevan \& Sutherland 1991; Mac Nally 2002). The independent effect of each separate explanatory variable on plant species richness of meadows and pastures was tested for significance $(P<0.05)$ using a randomisation routine $(\mathrm{n}=500$ randomisations; Mac Nally 
2000). The statistical significance was based on the upper 0.95 confidence limit $(Z$-scores $\geq 1.65$; Mac Nally 2002). Hierarchical partitioning was carried out using the 'hier.part package' (Version 1.0-1; Mac Nally \& Walsh 2004), which was run in conjunction with the R statistical package (R Development Core Team 2004). Prior to hierarchical partitioning, we started with careful univariate analysis and used, where appropriate, logarithmic transformation of the variables to improve linearity. The percentages were arcsine square-root transformed (Sokal \& Rohlf 1995).

\section{Results}

\section{General results}

In total, we identified 203 vascular plant species in the 60 grassland parcels, 155 of which were forbs and 48 were grasses. Within the management type mown meadow, 120 plant species were recorded, 26 of which (17 forbs and 9 grasses) occurred exclusively in this management type. In grazed grassland parcels, 177 plant species were recorded, 83 of which (72 forbs and 11 grasses) occurred only in pastures. In accordance to these results, comparison of the plant species richness of meadows and pastures revealed significantly higher numbers of plant species in pastures than in meadows (Table 1; Mann-Whitney U-test, $Z=3.1987, P=0.0014$ ).

The values of the explanatory variables of the three groups varied between meadows and pastures, but significant differences were only found for topography-related explanatory variables, except for solar radiation. The pastures had significantly higher values for both elevation and slope and lower values for soil quality than the meadows. The local management variable 'applied nitrogen fertilisation' varied within both management types, but the applied nitrogen fertilisation was not significantly higher in meadows (Mann-Whitney U-test; $Z=-1.6422, P=0.1006$ ). Moreover, the landscape structure variables showed no considerable differences between both management types considering the two spatial scales.

\section{Partitioning the variation in species richness of meadows}

The results of the forward selection of explanatory variables revealed that only nitrogen fertilisation had a significant effect on plant species richness of meadows (Table 2).

Neither topography-related explanatory variables nor landscape structure variables at either spatial scale appeared to affect the plant species of meadows significantly (all $P>0.1$ ). The pure effect of nitrogen fertilisation accounted for $45.9 \%(P=0.0010)$ of the variation in plant species richness, which showed a strong negative response to the applied nitrogen fertilisation. 
In hierarchical partitioning, solely the independent effect of the applied nitrogen fertilisation was statistically significant (Fig. 3 a) and showed the highest independent contribution to species richness of meadows (35.5\%). Local topography-related variables and landscape structure variables had no significant independent contributions on species richness of meadows. Overall, the results of the hierarchical partitioning were consistent with the variation partitioning results.

Table 2 Importance of the explanatory variables in the linear regression models for plant species richness of meadows $(n=30)$ and pastures $(n=30)$. The amount of explained variation $\left(R^{2}\right.$, equivalent to sum of all canonical eigenvalues, in \%) is given for each model. Directions of association $(-$ or +$)$ and $P$-values for significant variables $(P<0.1)$ are shown (see Table 1 for abbreviations).

\begin{tabular}{|c|c|c|c|c|c|c|c|c|}
\hline \multicolumn{3}{|c|}{ Topographic model (T) } & \multicolumn{3}{|c|}{ Management model (M) } & \multicolumn{3}{|c|}{ Landscape model (L) } \\
\hline Variable & $P$-value & $\mathrm{R}^{2}$ & Variable & $P$-value & $\mathrm{R}^{2}$ & Variable & $P$-value & $\mathrm{R}^{2}$ \\
\hline \multicolumn{9}{|c|}{ Meadow: Scale $250 \mathrm{~m}$} \\
\hline- & - & & $\mathrm{N}$ & $0.0010(-)$ & & - & - & \\
\hline - & & - & model & & 45.9 & - & & - \\
\hline \multicolumn{9}{|c|}{ Meadow: Scale 500 m } \\
\hline- & - & & $\mathrm{N}$ & $0.0010(-)$ & & - & - & \\
\hline- & & - & model & & 45.9 & - & & - \\
\hline \multicolumn{9}{|c|}{ Pasture: Scale $250 \mathrm{~m}$} \\
\hline SQ & $0.0050(-)$ & & $\mathrm{N}$ & $0.0619(-)$ & & PA_250 & $0.0200(-)$ & \\
\hline SLOPE & $0.0849(+)$ & & GRINT & $0.0969(+)$ & & & & \\
\hline model & & 36.4 & model & & 20.5 & model & & 17.2 \\
\hline \multicolumn{9}{|c|}{ Pasture: Scale $500 \mathrm{~m}$} \\
\hline SQ & $0.0050(-)$ & & $\mathrm{N}$ & $0.0619(-)$ & & PA_500 & $0.0080(-)$ & \\
\hline SLOPE & $0.0849(+)$ & & GRINT & $0.0969(+)$ & & & & \\
\hline model & & 36.4 & model & & 20.5 & model & & 22.9 \\
\hline
\end{tabular}

\section{Partitioning the variation in species richness of pastures}

The forward selection of variables for species richness of pastures included five explanatory variables from the three variable groups for each dataset. From the topographic models, soil quality and slope were selected, which together accounted for $36.4 \%$ of the variation in species richness. The management models showed a significant decrease in the number of plant species associated with higher amounts of nitrogen fertilisation, while plant species richness was positively influenced by grazing intensity. The selected explanatory variable 'percentage of arable land' had a significant negative effect on the species richness of pastures and the amount of explained variation increased 
with increasing spatial scale (17.2\% and $22.9 \%$ of the variation, respectively). As the best-fit landscape model included the explanatory variable 'percentage of arable land' at the spatial scale of $500 \mathrm{~m}$, we focused on this spatial scale.

Decomposing the total variation in plant species richness of pastures into variation fractions revealed that the largest fraction was accounted for by the pure effect of local topography-related variables (fraction A in Fig. 2; 25.2\%). The pure effect of landscape structure variables at the spatial scale of $500 \mathrm{~m}$ explained more variation than pure local field management variables, which were generally of minor importance in pastures. The largest shared fraction in the explained variation was related to the combined effect of local topography-related variables and local field management variables (fraction D in Fig. 2; 6.5\%). The negative combined effect of landscape structure and local management (fraction F in Fig. 2; -0.6\%) indicated that the corresponding variables of the two groups had opposite effects, i.e. one process was hindering the contribution of the other in the joint regression model (Legendre \& Legendre 1998).

The results of the hierarchical partitioning demonstrated that most of the explained variation was related to the joint effects of the explanatory variables (Fig. 3 b). The percentage of arable land at the spatial scale of $500 \mathrm{~m}$ had a higher independent contribution than soil quality and slope. Local field management variables had clearly lower independent effects than the local topography-related variables soil quality and slope as well as the landscape structure variable 'proportion of arable land', which was in accordance with the results of the variation partitioning. However, the results of the hierarchical partitioning were generally comparable to those obtained by variance partitioning. 


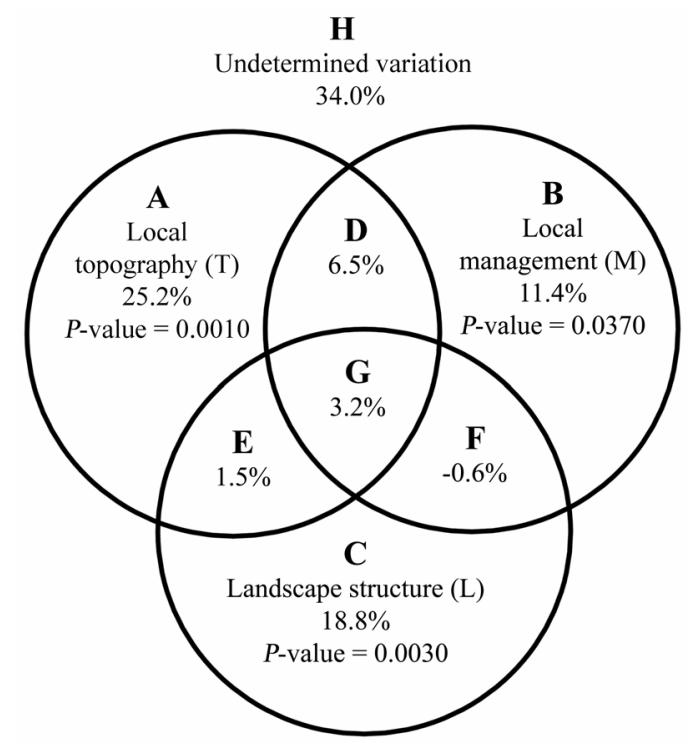

Fig. 2 Results of the variation partitioning for the plant species richness of pastures $(n=30)$ between local topography $(\mathrm{T})$, local management $(\mathrm{M})$ and landscape structure $(\mathrm{L})$ variables considering landscape structure at the spatial scale of $500 \mathrm{~m}$. Both pure (A, B and C) and combined effects $(D, E, F$ and $G)$ are shown. The fraction of variation explained $\left(R^{2}\right.$, in \%) is given for each component. $P$-values for pure components as determined by Monte Carlo permutation tests $(\mathrm{n}=$ $\left.10^{3}\right)$ are shown.

\section{Discussion}

In this study, the variation partitioning approach revealed that the response of plant species richness to local and landscape factors depended on the management regime. Species richness was generally significantly higher in grazed pastures than in mown meadows. Meadows were mostly structurally uniform, resulting in a decrease of available ecological niches. Homogeneity is usually increased by nitrogen fertilization due to high growth rates of dominant, tall growing grasses and competitive exclusion of sub-dominant species (Grime 1973). Jacquemyn, Brys \& Hermy (2003) suggested that mowing along with nitrogen fertilisation tends to decrease light availability strongly for small plants and seedlings, and as a result may cause their increased mortality and thus lower species richness. Furthermore, frequent mowing may contribute to dispersal limitation due to the removal of seeds with the harvested herbage (Maron \& Jefferies 2001).

The plant species richness of mown meadows was solely determined by the negative effect of the applied nitrogen fertilisation, which accounted for $45.9 \%$ of the variation in plant species 
richness. This result was also reflected by hierarchical partitioning, underlining a high independent effect of nitrogen fertilisation on the species richness of meadows. These findings conform to other studies that found pronounced decreases in species diversity after nitrogen addition (Grime 1973; Gough et al. 2000) and are in line with our first hypothesis.

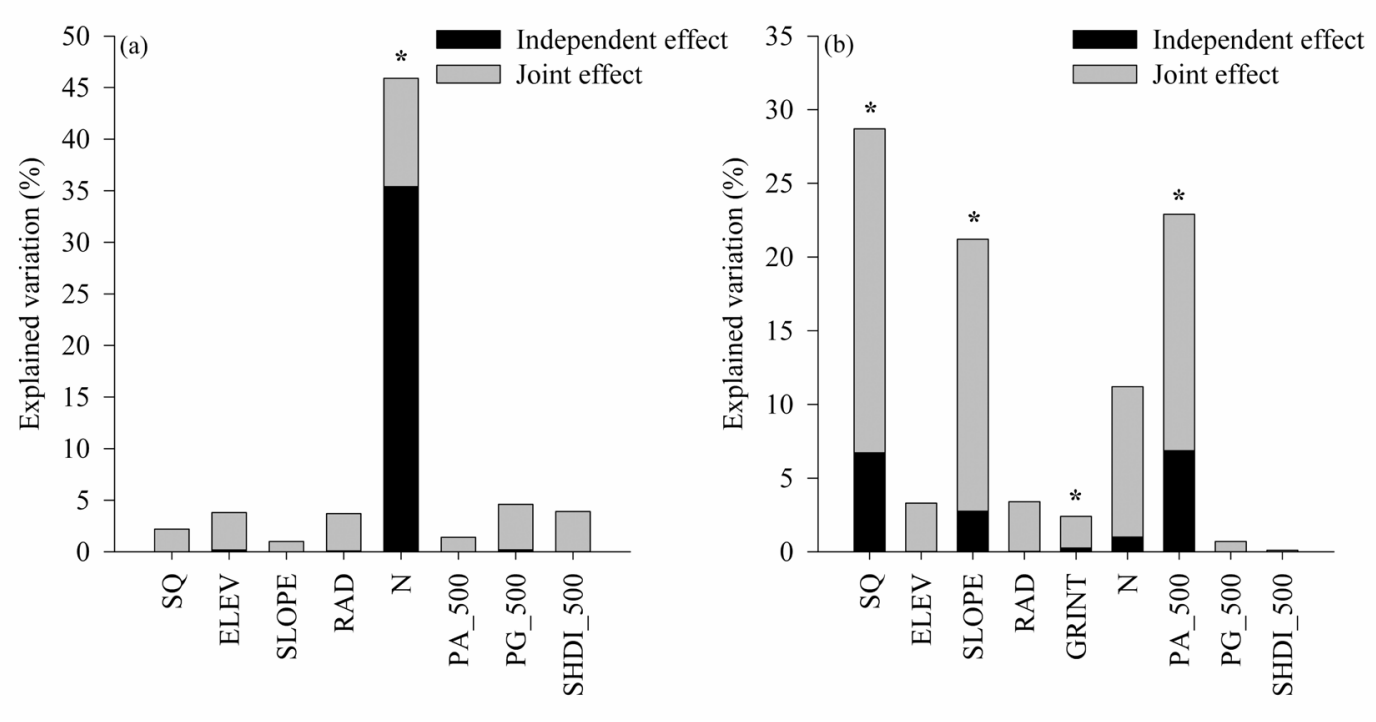

Fig. 3 The independent and joint effects (given as the percentage distribution of the total explained variation) of the explanatory variables (see Table 1 for abbreviations) calculated from hierarchical partitioning of the plant species richness of (a) meadows considering landscape structure variables at the spatial extent of $500 \mathrm{~m}$ and (b) pastures considering landscape structure variables at the spatial extent of $500 \mathrm{~m}$. The independent contributions of separate explanatory variables were tested for significance $\left({ }^{*} P<0.05\right)$ to explain variation in plant species richness using a randomisation routine.

In contrast to that of mown meadows, plant species richness of grazed pastures was determined by both local and landscape factors. The three groups of explanatory variables considered together in variation partitioning captured well the variation in the plant species richness of pastures: $66.0 \%$ of the variation was explained when including landscape structure variables at the spatial scale of $500 \mathrm{~m}$. The landscape model including the 'percentage of arable land' at the spatial scale of $250 \mathrm{~m}$ also significantly described plant species richness of pastures, but the fit of the model was less good ( $\mathrm{R}^{2}: 17.2 \%$ and $22.9 \%$ at the spatial scale of 250 and $500 \mathrm{~m}$ respectively; Table 2 ). In contrast to the hierarchical partitioning results, the relative contribution of the shared variation between the three 
sets of explanatory variables was of minor importance for the plant species richness of pastures. Nevertheless, hierarchical partitioning generally confirmed the selection of explanatory variables used in the variation partitioning procedure.

For the plant species richness of pastures, the pure effect of local topography-related variables and landscape structure variables was much more evident than the effect of local management variables in variation partitioning results. The positive relationship between plant species richness of pastures and slope indicated that steeper slopes were buffered to some extent against invasion by more competitive species. This could have been due to phosphorus limitation in the soils, as suggested by Bennie et al. (2006). A decrease in species richness of pastures has been attributed to increased soil quality along with higher contents of soil nutrients (Janssens et al. 1998). Given the strong effect of soil quality on species richness observed in the present study, it could be assumed that plant species richness of pastures was more affected by long-term nutrient conditions in the soil than by short-term effects due to nitrogen fertilisation. This assumption is confirmed by the partitioning results that revealed a relatively small effect of nitrogen fertilisation on the plant species richness of pastures.

Although the species richness of pastures decreased at high levels of fertilisation, grazing seemed more efficient in countering the negative effects of increased nitrogen than mowing. This result is consistent with those obtained by Jacquemyn, Brys \& Hermy (2003) for calcareous grasslands. Moreover, our results suggest that grazing at a moderate stocking rate positively affected the species richness of pastures, probably by reducing the abundance of competitive dominant species and thereby indirectly favouring inferior species, as suggested by Collins et al. (1998). Beneficial effects of grazing on plant species richness have also been shown by Pykälä (2005a) and low intensity livestock grazing has been suggested as being optimal for most grassland plants (McIntyre, Lavorel \& Tremont 1995; Olff \& Ritchie 1998).

Recent evidence suggested that local plant species richness results from interactions between processes operating at multiple spatial scales (Collins, Glenn \& Briggs 2002; Söderström et al. 2001). In line with our second hypothesis, our results confirmed an influence of the surrounding landscape on species richness in pastures, but not in meadows. The percentage of arable land in the surrounding landscape of pastures appeared as a significant predictor in both variance and hierarchical partitioning. According to the species pool concept (Pärtel et al. 1996), a homogeneous landscape dominated by arable land contains less plant species that are potentially able to disperse into the grassland habitat. Grazing animals may affect the dispersal of seeds and vegetative organs by a variety of mechanisms (Grime 2001; Vandvik \& Birks 2002). On the one hand, grassland 
species are dispersed by grazing animals from one pasture to another (Grime 2001) and migration distances of $3 \mathrm{~km}$ have been reported for alvar grassland species (Helm, Hanski \& Pärtel 2006). On the other hand, there is increasing evidence that grazing at a moderate stocking rate enhances plant species richness by creating small-scale disturbances in the soil and the sward structure and thereby enabling species establishment through vegetation gaps (McIntyre, Lavorel \& Tremont 1995; Olff \& Ritchie 1998; Adler, Raff \& Lauenroth 2001). It is very likely that both the dispersal by grazing animals and the colonisation of vegetation gaps after disturbance are negatively affected by a high percentage of arable land in the surrounding landscape.

Our results have implications for both grassland management practices and grassland conservation. In the present study, we were able to show that increased nitrogen fertilisation generally decreased plant species richness, but the negative effect was much more pronounced for meadows than for pastures. Moreover, the plant species richness of pastures was positively related to local site conditions such as steep slopes and low soil quality. From our findings, we conclude that grazing at moderate stocking rate contributed to high plant species richness. These results could provide useful information helping the farming community to adjust management practices in order to improve species richness of grasslands. In principal, extensive grazing systems have the potential to be integrated into contemporary grassland farming as labour requirements are low and individual livestock performances reasonably high (Pavlu et al. 2006). However, as farmers are for economic reasons usually forced to maintain high stocking rates in order to maximize output per area (Watkinson \& Ormerod 2001), compensation payments against intensification by means of agrienvironment subsidies are needed (Hodgson et al. 2005b). In this context, further research is required to develop regionally adjusted grazing management systems that ensure both sufficient income for the farmer and high species diversity.

This study further implies that future management policies should focus on improved habitat connectivity. Our results demonstrate a significant effect of landscape factors on biodiversity of grazed pastures. This should be taken into account when targeting specific conservation programmes, e.g. agri-environment schemes. There is an emerging consensus that agri-environment schemes could provide measurable benefits to farmland biodiversity when appropriately designed and targeted (Kleijn et al. 2004; Donald \& Evans 2006). Landscape effects on plant species richness may even gain in importance as plant populations are considered to respond slowly to habitat loss and fragmentation and consequently their level of threat might be underestimated (Helm, Hanski \& Pärtel 2006). For this reason, means have to be found to counteract the increasing fragmentation of the agricultural landscape. If biodiversity is managed via landscape structure by means of agri- 
environment schemes, our results suggest promoting coherent areas of grazed pastures at low to moderate intensity livestock grazing to preserve and enhance plant species richness in agricultural landscapes. Securing coherent areas of extensively managed pastures at the landscape level could combine biodiversity improvements with reduced costs for pasture management to the farmer.

\section{Acknowledgements}

We thank all farmers for giving permission to work on their fields, Carsten Thies for helpful comments on earlier drafts of the manuscript, Anne Richter gen. Kemmermann and Elke Bertke for the permission to use the plant species data, Jürgen Böhner for help in handling the large raster datasets and Susanne Kickner for her support with ArcInfo analyses. Finally, we would like to thank Nicole Wrage for her constructive comments. This research is part of the BIOPLEX project (Biodiversity and spatial complexity in agricultural landscapes under global change) funded by the German Federal Ministry of Education and Research (BMBF). L.M. was in receipt of a grant of the Aldo Gini foundation, Italy. 


\section{References}

Adler, P.B., Raff, D.A. \& Lauenroth, W.K. (2001) The effect of grazing on the spatial heterogeneity of vegetation. Oecologia, 128, 465-479.

Allen, V.G. (1991) Terminology for grazing lands and grazing animals. Pocahontas Press, Blacksbury, Virginia.

Anderson, D.R., Burnham, K.P. \& Thompson, W.L. (2000) Null hypothesis testing: Problems, prevalence, and an alternative. Journal of Wildlife Management, 64, 912-923.

Bakker, J.P. (1989) Nature Management by Grazing and Cutting. On the Ecological Significance of Grazing and Cutting Regimes Applied to Restore Former Species-Rich Grassland Communities in The Netherlands. Kluwer Academic Publishers, Dordrecht, The Netherlands.

Balmford, A., Bennun, L., Brink, B.T., Cooper, D., Côte, I.M., Crane, P., Dobson, A., Dudley, N., Dutton, I., Green, R.E., Gregory, R.D., Harrison, J., Kennedy, E.T., Kremen, C., LeaderWilliams, N., Lovejoy, T.E., Mace, G., May, R., Mayaux, P., Morling, P., Phillips, J., Redford, K., Ricketts, T.H., Rodriguez, J.P., Sanjayan, M., Schei, P.J., van Jaarsveld, A.S. \& Walther, B.A. (2005) The Convention on Biological Diversity's 2010 Target. Science, 307, 212-213.

Benjamin, K., Domon, G. \& Bouchard, A. (2005) Vegetation composition and succession of abandoned farmland: effects of ecological, historical and spatial factors. Landscape Ecology, 20, 627-647.

Bennie, J., Hill, M.O., Baxter, R. \& Huntley, B. (2006) Influence of slope and aspect on long-term vegetation change in British chalk grasslands. Journal of Ecology, 94, 355-368.

Beven, K.J. \& Kirkby, M.J. (1979) A physically based, variable contributing area model of basin hydrology. Hydrological Science Bulletin, 24, 43-69.

Borcard, D., Legendre, P. \& Drapeau, P. (1992) Partialling out the spatial component of ecological variation. Ecology, 73, 1045-1055.

Bullock, J.M., Franklin, J., Stevenson, M.J., Silvertown, J., Coulson, S.J., Gregory, S.J. \& Tofts, R. (2001) A plant trait analysis of responses to grazing in a long-term experiment. Journal of Applied Ecology, 38, 253-267.

Chevan, A. \& Sutherland, M. (1991) Hierarchical Partitioning. The American Statistician, 45, 9096.

Collins, S.L., Knapp, A.K., Briggs, J.M., Blair, J.M. \& Steinauer, E.M. (1998) Modulation of diversity by grazing and mowing in native tallgrass prairie. Science, 280, 745-747. 
Collins, S.L., Glenn, S.M. \& Briggs, J.M. (2002) Effects of local and regional processes on plant species richness in tallgrass prairie. Oikos, 99, 571-579.

Cottenie, K., Michels, E., Nuytten, N. \& De Meester, L. (2003) Zooplankton metacommunity structure: regional vs. local processes in highly interconnected ponds. Ecology, 84, 991-1000.

Cousins, S.A.O., Lavorel, S. \& Davies, I. (2003) Modelling the effects of landscape pattern and grazing regimes on the persistence of plant species with high conservation value in grasslands in south-eastern Sweden. Landscape Ecology, 18, 315-332.

Critchley, C.N.R., Burke, M.J.W. \& Stevens, D.P. (2004) Conservation of lowland semi-natural grasslands in the UK: a review of botanical monitoring results from agri-environment schemes. Biological Conservation, 115, 263-278.

Cushman, S.A. \& McGarigal, K. (2002) Hierarchical, multi-scale decomposition of speciesenvironment relationships. Landscape Ecology, 17, 637-646.

Dauber, J., Hirsch, M., Simmering, D., Waldhardt, R., Otte, A. \& Wolters, V. (2003) Landscape structure as an indicator of biodiversity: matrix effects on species richness. Agriculture, Ecosystems and Environment, 98, 321-329.

De Blois, S., Domon, G. \& Bouchard, A. (2002) Landscape issues in plant ecology. Ecography, 25, 244-256.

Donald, P.F. \& Evans, A.D. (2006) Habitat connectivity and matrix restoration: the wider implications of agri-environment schemes. Journal of Applied Ecology, 43, 209-218.

Geertsema, W., Opdam, P. \& Kropff, M.J. (2002) Plant strategies and agricultural landscapes: survival in spatially and temporally fragmented habitat. Landscape Ecology, 17, 263-279.

Gough, L. \& Grace, J.B. (1998) Herbivore effects on plant species density at varying productivity levels. Ecology, 79, 1586-1594.

Gough, L., Osenberg, C.W., Gross, K.L. \& Collins, S.L. (2000) Fertilization effects on species density and primary productivity in herbaceous plant communities. Oikos, 89, 428-439.

Grace, J.B. (1999) The factors controlling species density in herbaceous plant communities: an assessment. Perspectives in Plant Ecology Evolution and Systematics, 2, 1-28.

Grime, J.P. (1973) Competitive exclusion in herbaceous vegetation. Nature, 242, 344-347.

Grime, J.P. (2001) Plant strategies, vegetation processes, and ecosystem properties. 2nd ed., Wiley, Chichester, UK.

Heikkinen, R.K., Luoto, M., Kuussaari, M. \& Pöyry, J. (2005) New insights into butterflyenvironment relationships using partitioning methods. Proceedings of the Royal Society, 272, 2203-2210. 
Heikkinen, R.K., Luoto, M., Virkkala, R. \& Raino, K. (2004) Effects of habitat cover, landscape structure and spatial variables on the abundance of birds in an agricultural-forest mosaic. Journal of Applied Ecology, 41, 824-835.

Helm, A., Hanski, I. \& Pärtel, M. (2006) Slow response of plant species richness to habitat loss and fragmentation. Ecology Letters, 9, 72-77.

Hodgson, J.G., Grime, J.P., Wilson, P.J., Thompson, K. \& Band, S.R. (2005a) The impacts of agricultural change (1963-2003) on the grassland flora of Central England: processes and prospects. Basic and Applied Ecology, 6, 107-118.

Hodgson, J.G., Montserrat-Marti', G., Tallowin, J., Thompson, K., Díaz, S., Cabido, M., Grime, J.P, Wilson, P.J., Band, S.R., Bogard, A., Cabido, R., Cáceres, D., Castro-Díez, P., Ferrer, C. et al. (2005b) How much will it cost to save grassland diversity? Biological Conservation, 122, 263273.

Jacquemyn, H., Brys, R. \& Hermy, M. (2003) Short-time effects of different management regimes on the response of calcareous grassland vegetation to increased nitrogen. Biological Conservation, 111, 137-147.

Janssens, F., Peeters, A., Tallowin, J.R.B., Bakker, J.P., Bekker, R.M., Fillat, F. \& Oomes, M.J.M. (1998) Relationship between soil chemical factors and grassland diversity. Plant and Soil, 202, 69-78.

Jongman, R.H.G. (2002) Homogenisation and fragmentation of the European landscape: ecological consequences and solutions. Landscape and Urban Planning, 58, 211-221.

Kahmen, S., Poschlod, P. \& Schreiber, K.F. (2002) Conservation management of calcareous grasslands. Changes in plant species composition and response of functional traits during 25 years. Biological Conservation, 104, 319-328.

Kleijn, D., Berendse, F., Smit, R., Gilissen, N., Smit, J., Brak, B. \& Groeneveld, R. (2004) Ecological effectiveness of agri-environment schemes in different agricultural landscapes in the Netherlands. Conservation Biology, 18, 775-786.

Krauss, J., Klein, A.-M., Steffan-Dewenter, I. \& Tscharntke, T. (2004) Effects of habitat area, isolation, and landscape diversity on plant species richness of calcareous grasslands. Biodiversity and Conservation, 13, 1427-1439.

Legendre, P. \& Legendre, L. (1998) Numerical Ecology, 2nd English Edition. Elsevier Science BV, Amsterdam.

Lepš, J. (2005) Diversity and ecosystem function. In: van der Maarel, E. (Ed.), Vegetation Ecology. Blackwell Science Ltd, USA, pp. 199-237. 
Li, H. \& Wu, J. (2004) Use and misuse of landscape indices. Landscape Ecology, 19, 389-399.

Liu, Q. (1997) Variation partitioning by partial redundancy analysis (RDA). Environmetrics, 8, 7585 .

Maron, J.L. \& Jefferies, R.L. (2001) Restoring enriched grasslands: effects of mowing on species richness, productivity, and nitrogen retention. Ecological Applications, 11, 1088-1100.

McGarigal, K., Cushman, S.A., Neel, M.C. \& Ene, E. (2002) FRAGSTATS: Spatial Pattern Analysis Program for Categorical Maps. Computer software program produced by the authors at the University of Massachusetts, Amherst. Available at the following web site: www.umass.edu/landeco/research/fragstats/fragstats.html

McIntyre, S., Lavorel, S. \& Tremont, R.M. (1995) Plant life-history attributes: their relation to disturbance response in herbaceous vegetation. Journal of Ecology, 83, 31-44.

Mac Nally, R. (2000) Regression and model-building in conservation biology, biogeography and ecology: The distinction between - and reconciliation of - 'predictive' and 'explanatory' models. Biodiversity and Conservation, 9, 655-671.

Mac Nally, R. (2002) Multiple regression and inference in ecology and conservation biology: further comments on identifying important predictor variables. Biodiversity and Conservation, 11, 1397-1401.

Mac Nally, R. \& Walsh, C.J. (2004) Hierarchical partitioning public-domain software. Biodiversity and Conservation, 13, 659-660.

Moilanen, A. \& Nieminen, M. (2002) Simple connectivity measures in spatial ecology. Ecology, 83, 1131-1145.

Olff, H. \& Ritchie, M.E. (1998) Effects of herbivores on grassland plant diversity. Trends in Ecology and Evolution, 13, 261-265.

Olff, H. \& Ritchie, M.E. (2002) Fragmented nature: consequences for biodiversity. Landscape and Urban Planning, 58, 83-92.

Økland, R.H. \& Eilertsen, O. (1994) Canonical Correspondence Analysis with variation partitioning: some comments and an application. Journal of Vegetation Science, 5, 117-126.

Opitz von Boberfeld, W. (1994) Grünlandlehre - biologische und ökologische Grundlagen. Ulmer. Stuttgart, Germany.

Pärtel, M., Zobel, M., Zobel, K. \& van der Maarel, E. (1996) The species pool and its relation to species richness: evidence from Estonian plant communities. Oikos, 75, 111-117. 
Pavlu, V., Hejcman, M., Pavlu, L., Gaisler, J. \& Nezerkova, P. (2006) Effect of continuous grazing on forage quality, quantity and animal performance. Agriculture, Ecosystems and Environment, 113, 349-355.

Pykälä, J. (2005a) Plant species responses to cattle grazing in mesic semi-natural grassland. Agriculture, Ecosystems and Environment, 108, 109-117.

Pykälä, J., Luoto, M., Heikkinen, R.K. \& Kontula, T. (2005b) Plant species richness and persistence of rare plants in abandoned semi-natural grasslands in northern Europe. Basic and Applied Ecology, 6, 25-33.

R Development Core Team (2004) $R$ : a language and environment for statistical computing. Vienna, Austria: R Foundation for Statistical Computing. http://www.R-project.org

Rook, A.J., Dumont, B., Isselstein, J., Osoro, K., WallisDeVries, M.F., Parente G. \& Mills, J. (2004) Matching type of livestock to desired biodiversity outcomes in pastures - a review. Biological Conservation, 119, 137-150.

Roschewitz, I., Gabriel, D., Tscharntke, T. \& Thies, C. (2005) The effects of landscape complexity on arable weed species diversity in organic and conventional farming. Journal of Applied Ecology, 42, 873-882.

Rothkegel, W. (1952) Landwirtschaftliche Schätzungslehre. Stuttgart, Ulmer, Germany.

Söderström, B., Svensson, B., Vessby, K. \& Glimskär, A. (2001) Plants, insects and birds in seminatural pastures in relation to local habitat and landscape factors. Biodiversity and Conservation, 10, 1839-1863.

Sokal, R.R. \& Rohlf, F.J. (1995) Biometry: The Principles of Statistics in Biological Research. 3rd ed. W.H. Freeman, New York, NY.

Steffan-Dewenter, I., Münzenberg, U., Bürger, C., Thies, C. \& Tscharntke, T. (2002) Scaledependent effects of landscape context on three pollinator guilds. Ecology, 83, 1421-1432.

Ter Braak, C.J.F. (1995) Ordination. In: Jongman, R.H.G., Ter Braak, C.J.F. \& Van Tongeren, O.F.R. (Eds.), Data analysis in community and landscape ecology. 2nd ed. Pudoc, Wageningen, the Netherlands, Reissued in 1995 by Cambridge Univ. Press, pp. 91-173.

Ter Braak, C.J.F. \& Smilauer, P. (2002) CANOCO Reference manual and CanoDraw for Windows User's guide: Software for Canonical Community Ordination (version 4.5). Microcomputer Power (Ithaca, NY, USA).

Tscharntke, T., Klein, A.-M., Kruess, A., Steffan-Dewenter, I. \& Thies, C. (2005) Landscape perspectives on agricultural intensification and biodiversity - ecosystem service management. Ecology Letters, 8, 857-874. 
Vandvik, V. \& Birks, H.J.B. (2002) Partitioning floristic variance in Norwegian upland grasslands into within-site and between-site components: are the patterns determined by environment or by land-use? Plant Ecology, 162, 233-245.

Watkinson, A.R. \& Ormerod, S.J. (2001) Grasslands, grazing and biodiversity: editors' introduction. Journal of Applied Ecology, 38, 233-237.

Weibull, A.C., Östman, Ö. \& Granqvist, A. (2003) Species richness in agroecosystems: the effect of landscape, habitat and farm management. Biodiversity and Conservation, 12, 1335-1355.

Whittaker, R.J., Willis, K.J. \& Field, R. (2001) Scale and species richness: towards a general, hierarchical theory of species diversity. Journal of Biogeography, 28, 453-470.

Wisskirchen, R. \& Haeupler, H. (1998) Standardliste der Farn- und Blütenpflanzen Deutschlands. Ulmer, Stuttgart, Germany. 


\section{CHAPTER}

4

Effects of management regime, nitrogen fertilisation and abiotic factors on local-regional patterns of plant species richness in managed temperate grasslands

In preparation 


\begin{abstract}
Understanding patterns of vascular plant diversity in managed temperate grasslands and the processes that determined them requires analyses at multiple spatial scales and across a large variety of grassland utilisation systems. Here, we analysed the effects of management regime (meadow vs. pasture), nitrogen fertilisation and abiotic environmental factors on vascular plant species richness. Using the additive partitioning approach, we quantified $\alpha$-, $\beta$ - and $\gamma$-diversity components for each management regime at two spatial scales, the local field scale and the regional scale. $\alpha-, \beta$ - and $\gamma$ diversity were higher in grazed pastures than in mown meadows at both spatial scales. Our results revealed that for both management regimes the heterogeneity between the grassland parcels ( $\beta$ diversity) at the regional scale contributed most to the overall observed regional $\gamma$-diversity (proportions ranged from 80 to $91 \%$ ). Low application rates of nitrogen fertilisers and abiotic environmental conditions such as soils with a low nutrient status and steep slopes positively affected vascular plant species richness in grasslands. Although the management regime did not show the dominant effect in explaining local-regional patterns of species richness, the results indicate an indirect contribution of low-to-moderate livestock grazing to a high species richness as pastures were mainly located on steeply sloping grounds with poor soil quality. We conclude, that the maintenance of a large variety of grassland utilisation systems can allow the conservation of a wide diversity of grassland plants. Particularly, the maintenance and re-establishment of grazing along with a spatially varied disturbance regime at large areas with heterogeneous abiotic environmental conditions could facilitate successful management of vascular plant species diversity.
\end{abstract}

Keywords: Additive partitioning, ANCOVA, meadow, pasture, spatial scale 


\section{Introduction}

Temperate semi-natural grasslands resulting from a long history of traditional low-intensity farming systems have been recognised as an important biodiversity resource in agricultural areas within the European Union (Söderström et al., 2001; WallisDeVries et al., 2002; Myklestad \& Sætersdal, 2004). Such man-made grasslands are of great nature conservation interest, as they may harbour a very high small-scale species density compared to other community types (Pärtel et al., 1996), and make an important contribution to the total biodiversity of the rural landscapes (Nösberger and Rodriguez, 1996). Over the last decades, the amount of semi-natural grasslands and their associated flora and fauna decreased due to intensification of farming systems, abandonment and fragmentation (Critchley et al., 2002; Zechtmeister et al., 2003; Hodgson et al., 2005).

At the local field scale, changes in farm management practices associated with agricultural intensification decreased the actual pool of species present in the respective community (Pärtel et al., 1996) primarily due to greater fertiliser inputs and increased defoliation frequencies (Fuller, 1987; Garcia, 1992; Plantureux et al., 2005). At the regional scale, agricultural intensification implicated farm enlargement and field consolidation accompanied by abandonment of less fertile soils with marginal yields (Benton et al., 2003; Tscharntke et al., 2005). As a consequence, the formerly large regional variety of grassland utilisation systems strongly decreased, benefiting spatially and structurally uniformly managed grassland areas that resulted in a homogenisation of the landscape. Besides homogenisation (Jongman, 2002), the fragmentation of the remaining seminatural grasslands caused species loss on the long run as ecological processes such as dispersal, recruitment and persistence of local populations were limited due to reduced connectivity (Kiviniemi and Eriksson, 2002; Helm et al. 2006).

These threats indicated a pressing need for the introduction of agri-environment schemes that are presently considered the most important policy instruments to maintain or re-establish biodiversity in European agricultural areas (Kleijn et al., 2006). These policy instruments are suggested to provide measurable benefits to wildlife populations when appropriately designed and targeted (Kleijn et al., 2001; Vickery et al., 2004; Donald and Evans, 2006).

In order to enhance the efficiency of management measures prescribed in agri-environment schemes, recent studies suggested the need to adopt a multi-scale approach (Tscharntke et al., 2005; Donald and Evans, 2006). As plant species distributions in a landscape are the result of processes operating at both local and regional scales (Ricklefs, 1987; Collins et al., 2002; Münzbergová, 2004), it is therefore essential to quantify species diversity at multiple scales using a broad range of 
site conditions. To measure species diversity at different spatial scales, we partitioned the total species richness into additive components within and between communities (Lande, 1996; Wagner et al., 2000; Veech et al., 2002; Gering et al., 2003; Martin et al., 2005). Using this additive approach, the species richness is partitioned into alpha and beta components at both the local and the regional scale, therewith providing understanding of local-regional patterns of species richness and spatial scale dependence of diversity components (Veech et al., 2002).

In general, it is widely accepted that species richness in a community is determined by local processes such as competition, disturbance regime and biotic interactions (Ricklefs, 1987; Grace, 1999; Grime, 2001). Moreover, there is evidence that the community structure and its dynamics are governed by the regional species pool and dispersal limitations (Pärtel et al., 1996; Poschlod et al., 2005). Management regimes like mowing and livestock grazing affect plant species diversity in grasslands, especially by their intensity and continuity (Smith et al., 1996). One the one hand, high grassland biodiversity has been associated with decreased cutting frequency and late mowing (Moog et al., 2002). On the other hand, vascular plant species richness of semi-natural grasslands has been demonstrated to benefit from low-to-moderate intensity livestock grazing at stocking rates less than one livestock unit per hectare (Collins et al., 1998; Duru and Hubert, 2003). As most species-rich grasslands are adapted to low nutrient conditions, high amounts of nitrogen fertiliser inputs generally decreased the species richness (Jacquemyn et al., 2003; Plantureux et al., 2005). In addition, vascular plant species diversity in grasslands is related to abiotic environmental factors including soil and topography-related physical attributes (Critchley et al., 2002; Pykälä et al., 2005; Bennie et al., 2006).

In this study, we first analysed the effects of management regime (meadow vs. pasture), nitrogen fertilisation and abiotic environmental factors (slope angle and soil quality) on vascular plant species richness in managed grasslands at two spatial scales. At both the local and the regional scale, we quantified vascular plant species richness by partitioning the number of species into the additive components $\alpha$-, $\beta$-, and $\gamma$-diversity. Second, we tested whether a subset of vascular plant species can be used as indicators for overall plant diversity. The identification of potential indicators that allow to easily assess the conservation value of a site or region is still lacking (Duelli and Obrist, 1998; Pearman et al., 2006; Wittig et al., 2006). Specifically we asked the following. (i) How does the additive partitioning of species diversity differ between mowing and grazing management? (ii) How important is the grassland management regime compared with the influence of nitrogen fertilisation and abiotic environmental factors on the additive species diversity 
components? (iii) Is the effect of grassland management regime different for all plant species compared to forb and indicator species?

\section{Materials and methods}

\section{Study area and sampling design}

The study area is situated in the southern part of Lower Saxony, Germany (approximate north-south boundaries $51^{\circ} 95^{\prime} \mathrm{N}$ to $51^{\circ} 61^{\prime} \mathrm{N}$ ). This area covers approximately $1260 \mathrm{~km}^{2}$ and is dominated by agricultural land use, covering c. $38 \%$ of the region, and large contiguous forest-covered areas in the hilly regions. The mean annual temperature is $8.7^{\circ} \mathrm{C}$ and the annual precipitation averages 645 $\mathrm{mm}$. The relief gradient is rather high, with altitudes above sea level ranging from $72 \mathrm{~m}$ in the lowlands to $527 \mathrm{~m}$ in the wooded hillsides of the western part of the study area. Within the agricultural landscape, patchily distributed fragments of agriculturally improved, species-poor grassland are mainly located in the lowland areas. Semi-natural, species-rich grassland that had not experienced any agricultural improvement prevail predominantly in the steeper areas.

In this study, we investigated vegetation composition in 60 managed grassland parcels belonging to 30 different farms. The vegetation surveys were carried out at 30 meadows that were cut only without aftermath grazing and 30 grazed pastures. We first selected the grassland parcels to account for regionally characteristic management practices, and then interviewed the farmers to record relevant management measures. All the investigated parcels were spatially independent, with a minimum distance of at least $500 \mathrm{~m}$. The geographic position of each grassland parcel was recorded with differential GPS and the parcels were digitalised by means of the geographic information system (GIS) ArcGIS (Version 8.3; ESRI Inc., Redlands, California). A range of grassland community types were investigated within the study area. These included mesic and intensively managed meadows and pastures on neutral to moderately acid soils (Arrhenatherion elatioris, Cynosurion), meadows on moist to wet soils (Calthion), limestone grasslands (Mesobromion erecti) and fragments of matgras swards (Nardion) on acid soils. Nomenclature of phytosociological units is according to Oberdorfer and Müller (1993).

In May/June 2002 and 2004, three circular vegetation plots of $12.6 \mathrm{~m}^{2}$ (radius $2 \mathrm{~m}$ ) were sampled once in each grassland parcel before the first cut or the beginning of the grazing period, respectively. Within each grassland parcel, the vegetation plots were placed at a distance of $10 \mathrm{~m}$ from each other. Edge effects were avoided by excluding a 10-meter buffer zone from the parcel boundary. In each circular vegetation plot, all the vascular plant species were identified to species 
level; tree seedlings were not considered. Species nomenclature followed that of Wisskirchen and Haeupler (1998).

\section{Management and environmental variables}

For each grassland parcel, we recorded information about management intensity by interviewing the farmers using a standardised questionnaire. The meadows were cut one to four times per year, with an average of three cuts. Intensively managed meadows, cut for silage, were mostly fertilised with mineral fertilisers between the cuts and the time of the first cut was approximately the mid of May. Extensively managed meadows, cut for hay, were fertilised at low levels and were cut once or twice a year. The time of the first cut was around the second half of June. The investigated grazed pastures were mostly fertilised with farmyard manure and liquid manure, while mineral fertilisers were rarely applied. The corresponding contents of nitrogen $(\mathrm{N})$, phosphorus $(\mathrm{P})$ and potassium $(\mathrm{K})$ in organic fertilisers were retrieved from Walther et al. (1994). Grazing intensity was estimated considering the type of grazing animal, stocking rates, timing and duration (Opitz von Boberfeld, 1994). The data on stocking rates were converted to standard livestock units (SLU) per hectare and year using a standard bovine weighting $500 \mathrm{~kg}$ (Allen, 1991). Pastures were mainly utilised by rotational cattle-grazing with a mean stocking density of one livestock unit per hectare and year. As $\mathrm{N}, \mathrm{P}$, and $\mathrm{K}$ in fertilisers were highly correlated (Spearman rank correlation coefficient $\mathrm{r}_{\mathrm{s}}>0.5$, $P<0.01$ ), only the total amount of nitrogen fertilisers applied was used as a surrogate for fertilisation intensity in this study. The total amount of $\mathrm{N}$ fertilisers was calculated by summing up organic and mineral $\mathrm{N}$.

Abiotic environmental variables were spatially derived using a high resolution digital elevation model (DEM) with a cell size of $12.5 \mathrm{~m}$ and soil data from vector-based soil maps (scale $1: 5$ 000). Based on the DEM, we calculated the mean slope angle (inclination in degree) for each grassland parcel using SAGA GIS Version 2.1 (available at http://www.saga-gis.org/). Additionally, the environmental variable soil quality, based on digital soil evaluation data, was derived using vectorbased digital soil maps. This continuous predictor variable incorporates parameters describing the productiveness and fertility of agricultural land such as soil type and soil genesis (Rothkegel, 1952). The area-weighted mean soil quality was determined for each grassland parcel.

\section{Additive partitioning of plant species richness}

The total observed species richness was partitioned into scale-specific diversity components separated for each management regime (meadow/pasture) at two spatial scales, the local field scale 
and the regional scale, using the additive partitioning approach (Lande, 1996; Wagner et al., 2000; Veech et al., 2002; Gering et al., 2003). Within the context of this study, plant species richness was used as a measure of species diversity. The sampling unit at the local field scale was represented by the vegetation plot within each grassland parcel (meadow/pasture), and the regional scale by the grassland parcels separated by management regime within the study area. The $\alpha$-diversity (withinunit diversity) was the average number of plant species found in a sampling unit (per vegetation plot in a grassland parcel, or in all grassland parcels within the study area). The total species diversity ( $\gamma$-diversity) was the number of species found in the pooled sampling unit, e.g. in all three vegetation plots per grassland parcel, or in all grassland parcels within the study area. For both spatial scales, we calculated the $\beta$-diversity (between-unit diversity) by subtracting $\alpha$ from $\gamma$ (Gering et al., 2003). As the average $\gamma$-diversity at the local field scale is equivalent to the average $\alpha$ diversity at the regional scale, the total diversity at the regional scale can be determined by summing up $\alpha$-, and $\beta$-diversity at the local field scale plus $\beta$-diversity at the regional scale $\left(\gamma_{\text {region }}=\alpha_{\text {field }}+\beta_{\text {field }}+\beta_{\text {region }}\right)$.

For both spatial scales, we additionally conducted separate analyses for forb (dicotyledonous species) and indicator plant species using the additive partitioning approach. The regionally adjusted identification and selection of potential indicator species (only vascular plants) for biodiversity conservation and management was conducted by a priori analysis of large synoptic phytosociological tables (e.g. Oberdorfer and Müller, 1993). Based on these tables, very rare and highly common species within the regional species pool were eliminated. In this study, the establishment of a regional list of potential indicator species aimed to link the ecological value of a grassland parcel to the occurrence of these indicator species (for abundances of indicator species according to management regime see the Appendix). A similar approach has recently been tested in Lower Saxony, Germany (Wittig et al., 2006) and has already been implemented in the province of Baden-Württemberg in South-western Germany (Oppermann and Briemle, 2004).

\section{Statistical analysis}

For the analysis of both the continuous environment and management variables and species diversity components, we used parametric $t$-tests for testing the null hypotheses that there is no difference between the management regimes in the corresponding mean values (Sokal and Rohlf, 1995). The assumption of variance homogeneity across groups was tested by means of Levene's tests. To meet the normality assumption, the environment variable soil quality was log transformed $[\log (n+1)]$ prior to analysis. Analyses of covariance (ANCOVAs) were carried out to test the main 
and first-order interaction effects of the categorical factor management regime (meadow/pasture) on the obtained $\alpha-, \beta$-, and $\gamma$-diversity components, adjusted for the effects of the three continuous covariates soil quality, slope angle and nitrogen fertilisation. The ANCOVA models were run under the univariate SPSS routine (Version 14.0, SPSS Inc., Chicago Illinois, USA) using type-III sum of squares. To obtain the most appropriate models explaining species diversity components, a backward stepwise selection procedure was applied. First, non-significant first-order interactions between the factor and each covariate and between covariates $(P>0.05)$ were removed before rerunning the analyses. Next, non-significant main effects were excluded. Following Crawley (2002), non-significant main effects that figured in significant interaction terms were not removed from the final models. Application of ANCOVA was supported by examining linearity of relationships with scatterplots. Homogeneity of variances and normal distribution of errors were verified by examining plots of the distribution of residuals and of the residuals against fitted values to fulfil statistical assumptions of ANCOVA (Quinn and Kough, 2002).

Pre-analyses

Descriptive statistics of continuous environment and management covariates used in the analyses are shown in Table 1. There was no significant difference in mean total amount of nitrogen fertilisers applied between mowing and grazing management $(t=1.932, P=0.06)$, whereas the means of soil quality and slope differed significantly between the two management regimes ( $t=3.256, P=0.002$ and $t=-5.248, P<0.001$; respectively). As ANCOVA is sensitive to mulicollinearity among the covariates (Quinn and Kough, 2002), we examined a matrix of Pearson correlation coefficients prior to analyses. All three covariates were not clearly redundant (Pearson correlation coefficient $r<0.5$ ) and hence, the multiple covariates were included to fit the linear ANCOVA models.

Moreover, spatial autocorrelation in species composition was tested using the Mantel test (Legendre and Legendre, 1998) to relate a matrix of similarities between grassland parcels to a matrix of geographic distances between parcels. Floristic distances between parcels based on species presence or absence were calculated using the complement of the Jaccard similarity index (Magurran, 2004). Mantel tests were generated for the nonparametric correlation (based on Spearman rank correlations, 1000 permutations) between plant community and distance matrices for all grassland parcels and for each management regime separately, but Mantel statistics revealed no spatial autocorrelation (for all grassland parcels: $P=0.170, \mathrm{r}_{\mathrm{s}}=0.051, n=60$; for meadows: $P=0.129, \mathrm{r}_{\mathrm{s}}=0.105, n=30$; for pastures: $\left.P=0.244, \mathrm{r}_{\mathrm{s}}=0.059, n=30\right)$. 
Table 1. Descriptive statistics (mean and standard deviation) of continuous environment and management variables used in the analyses (Meadows: $n=30$; Pastures: $n=30$ ). Different letters indicate significant differences $(P<0.05)$ between means resulting from $t$-tests.

\begin{tabular}{|c|c|c|c|c|c|}
\hline \multirow[t]{2}{*}{ Variable } & \multirow[t]{2}{*}{ Abbr. } & \multicolumn{2}{|c|}{ Meadow } & \multicolumn{2}{|c|}{ Pasture } \\
\hline & & Mean & SD & Mean & SD \\
\hline Nitrogen fertilisation $\left(\mathrm{kg} \mathrm{N} \mathrm{ha}^{-1}\right.$ year $\left.^{-1}\right)$ & $\mathrm{N}$ & $132.0^{\mathrm{a}}$ & 90.8 & $93.0^{\mathrm{a}}$ & 63.6 \\
\hline Mean slope angle (inclination in deg) & SLOPE & $5.1^{\mathrm{a}}$ & 3.8 & $10.7^{\mathrm{b}}$ & 4.4 \\
\hline Mean soil quality & SQ & $54.1^{\mathrm{a}}$ & 12.3 & $44.9^{\mathrm{b}}$ & 8.3 \\
\hline
\end{tabular}

${ }^{\S}$ Soil quality ranges from zero to hundred; high values indicate a high soil quality for agricultural production and low values reflect poor soil quality.

\section{Results}

Additive partitioning of all plant species and forb species

In total, 203 vascular plant species were identified in the 60 grassland parcels, 155 of which were forbs (dicotyledonous species) and 48 were grasses (monocotyledonous species). Within the mown meadows, 120 plant species were recorded, 26 of which (17 forbs and 9 grasses) occurred exclusively in this management regime. In grazed grassland parcels, 177 plant species were recorded, 83 of which (72 forbs and 11 grasses) occurred only in pastures. The $\alpha-, \beta-$, and $\gamma$ diversities at the field scale were significantly higher in pastures than in meadows (Table 2). The $\beta$ diversity among meadows and pastures at the regional scale made the greatest contribution to the observed regional $\gamma$-diversity of all plant species (96.2 and 145.9 species, respectively; Fig. 1). The same pattern held true for forb species, where the proportion of $\beta$-diversity among meadows and pastures at the regional scale was much greater than the proportion of $\alpha-$, and $\beta$ diversity at the local field scale. 
Table 2. The alpha $\left(\alpha_{\mathrm{f}}\right)$, beta $\left(\beta_{\mathrm{f}}\right)$ and gamma $\left(\gamma_{\mathrm{f}}\right)$ plant species diversity at the field scale calculated for all plant species, forb species and indicator species. Means $\pm \mathrm{SD}$, minima and maxima are given for 30 meadows and 30 pastures. Different letters represent significant differences $(P<0.05)$ between means resulting from $t$-tests.

\begin{tabular}{|c|c|c|c|c|c|c|}
\hline & \multicolumn{2}{|l|}{ Mean \pm SD } & \multicolumn{2}{|c|}{ Minimum } & \multicolumn{2}{|c|}{ Maximum } \\
\hline & Meadow & Pasture & Meadow & Pasture & Meadow & Pasture \\
\hline \multicolumn{7}{|c|}{ All plant species } \\
\hline$\alpha_{\mathrm{f}}$ & $15.3 \pm 4.6^{\mathrm{a}}$ & $19.2 \pm 5.4^{\mathrm{b}}$ & 8.0 & 8.3 & 25.0 & 32.7 \\
\hline$\beta_{\mathrm{f}}$ & $8.5 \pm 3.3^{\mathrm{a}}$ & $11.9 \pm 5.3^{\mathrm{b}}$ & 3.0 & 2.7 & 17.7 & 29.3 \\
\hline$\gamma_{\mathrm{f}}$ & $23.8 \pm 7.1^{\mathrm{a}}$ & $31.1 \pm 10.0^{b}$ & 14.0 & 11.0 & 39.0 & 62.0 \\
\hline \multicolumn{7}{|c|}{ Forb species } \\
\hline$\alpha_{\mathrm{f}}$ & $7.6 \pm 3.9^{\mathrm{a}}$ & $11.4 \pm 4.8^{\mathrm{b}}$ & 2.3 & 5.0 & 15.3 & 27.0 \\
\hline$\beta_{\mathrm{f}}$ & $5.6 \pm 3.0^{\mathrm{a}}$ & $8.6 \pm 4.1^{\mathrm{b}}$ & 1.0 & 2.0 & 14.3 & 20.7 \\
\hline$\gamma_{\mathrm{f}}$ & $13.1 \pm 6.3^{\mathrm{a}}$ & $20.0 \pm 8.4^{\mathrm{b}}$ & 5.0 & 7.0 & 28.0 & 42.0 \\
\hline \multicolumn{7}{|c|}{ Indicator species } \\
\hline$\alpha_{\mathrm{f}}$ & $1.2 \pm 1.4^{\mathrm{a}}$ & $2.5 \pm 2.2^{b}$ & 0.0 & 0.0 & 5.3 & 9.0 \\
\hline$\beta_{\mathrm{f}}$ & $0.9 \pm 1.1^{\mathrm{a}}$ & $2.2 \pm 2.0^{\mathrm{b}}$ & 0.0 & 0.0 & 4.0 & 9.3 \\
\hline$\gamma_{\mathrm{f}}$ & $2.1 \pm 2.4^{\mathrm{a}}$ & $4.7 \pm 3.9^{b}$ & 0.0 & 0.0 & 9.0 & 18.0 \\
\hline
\end{tabular}

The diversity components of all and forb plant species were mainly related to the amount of nitrogen fertilisers applied (Table 3). The $\alpha$-diversity of all plant species varied significantly between mowing and grazing management and showed a negative relation to nitrogen fertilisation (Fig. 2a). Unlike the $\alpha$-diversity of all plant species, the $\alpha$-diversity of forb species was significantly related to slope angle as well as nitrogen fertilisation (Fig. 2b). Moreover, soil quality showed a stronger negative relation to the $\alpha$-diversity of forb species in grassland parcels situated on steeper slopes compared to more flat areas $(P<0.05$ for interaction term soil quality $\times$ slope; for illustration see Fig. 3). The significant interaction term between the management regime and soil quality for the $\beta$-, and $\gamma$-diversity of all plant species indicated that the response to soil quality was significantly different between management regimes. 

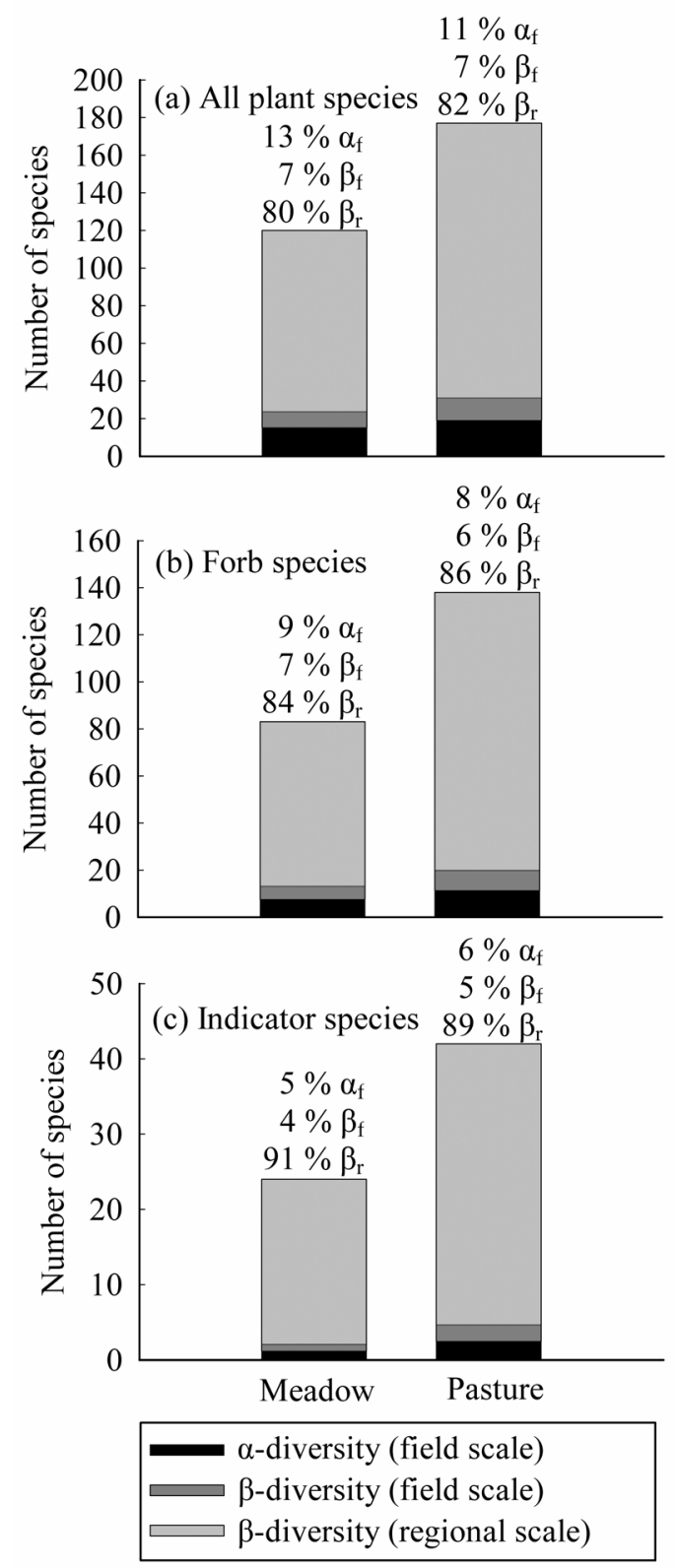

Fig. 1. The total regional diversity of (a) all, (b) forb, and (c) indicator plant species using the additive partitioning method for 30 mown meadows and 30 grazed pastures. Regional gamma values $\left(\gamma_{\mathrm{r}}\right)$ are represented by the top line of each bar. The proportions of $\gamma_{\mathrm{r}}$ that are the sum of $\alpha_{\mathrm{f}}, \beta_{\mathrm{f}}$ and $\beta_{\mathrm{r}}$ are given by percentages above each bar. 
Table 3. Results of ANCOVA evaluating effects of management regime (MANAG) of grassland fields (Meadow, Pasture), with soil quality (SQ), slope angle (SLOPE) and nitrogen fertilisation (N) as covariates, on $\alpha$-, $\beta$ - and $\gamma$-diversity of plant species at the field scale $(n=60)$. Only significant first-order interactions are shown. Significance: $*=P<0.05, * *=P<0.01$; $* *=P<0.001$; n.s. $=$ not significant.

\begin{tabular}{|c|c|c|c|c|c|c|c|c|c|}
\hline \multirow[b]{2}{*}{ Source of variation } & \multicolumn{3}{|c|}{ (a) All plant species } & \multicolumn{3}{|c|}{ (b) Forb species } & \multicolumn{3}{|c|}{ (c) Indicator species } \\
\hline & \multicolumn{3}{|c|}{$\begin{array}{l}\text { d.f. square } F \\
\alpha \text {-diversity } \\
\left(\mathrm{R}^{2}=0.40\right)\end{array}$} & \multicolumn{3}{|c|}{$\begin{array}{l}\text { d.f. square } F \\
\alpha \text {-diversity } \\
\left(\mathrm{R}^{2}=0.47\right)\end{array}$} & \multicolumn{3}{|c|}{$\begin{array}{l}\text { d.f. square } F \\
\alpha \text {-diversity } \\
\left(\mathrm{R}^{2}=0.40\right)\end{array}$} \\
\hline MANAG & 1 & 88.1 & $5.0^{*}$ & - & - & n.s. & - & - & n.s. \\
\hline SQ & - & - & n.s. & 1 & 4.9 & 0.4 & 1 & 1.6 & 0.7 \\
\hline SLOPE & - & - & n.s. & 1 & 68.8 & $5.3 *$ & 1 & 15.4 & $6.5^{*}$ \\
\hline $\mathrm{N}$ & 1 & 453.8 & $25.8^{* * *}$ & 1 & 272.2 & $21.0 * * *$ & 1 & 33.3 & $14.0 * * *$ \\
\hline $\mathrm{SQ} \times \mathrm{SLOPE}$ & - & - & - & 1 & 64.0 & $4.9^{*}$ & 1 & 14.7 & $6.2^{*}$ \\
\hline \multirow[t]{2}{*}{ Residual } & 57 & 17.6 & & 55 & 13.0 & & 55 & 2.4 & \\
\hline & \multicolumn{3}{|c|}{$\begin{array}{l}\beta \text {-diversity } \\
\left(\mathrm{R}^{2}=0.36\right)\end{array}$} & \multicolumn{3}{|c|}{$\begin{array}{l}\beta \text {-diversity } \\
\left(\mathrm{R}^{2}=0.27\right)\end{array}$} & \multicolumn{3}{|c|}{$\begin{array}{l}\beta \text {-diversity } \\
\left(\mathrm{R}^{2}=0.29\right)\end{array}$} \\
\hline MANAG & 1 & 80.4 & $5.4^{*}$ & - & - & n.s. & - & - & n.s. \\
\hline SQ & 1 & 102.7 & $6.8^{*}$ & 1 & 87.5 & $7.7 * *$ & 1 & 14.9 & $6.7^{*}$ \\
\hline SLOPE & - & - & n.s. & - & - & n.s. & - & - & n.s. \\
\hline $\mathrm{N}$ & 1 & 90.8 & $6.0^{*}$ & 1 & 85.7 & $7.5^{* *}$ & 1 & 23.3 & $10.5^{* *}$ \\
\hline MANAG $\times$ SQ & 1 & 74.4 & $5.0^{*}$ & - & - & - & - & - & - \\
\hline \multirow[t]{2}{*}{ Residual } & 55 & 15.0 & & 57 & 11.4 & & 57 & 2.2 & \\
\hline & \multicolumn{3}{|c|}{$\begin{array}{l}\gamma \text {-diversity } \\
\left(\mathrm{R}^{2}=0.46\right)\end{array}$} & \multicolumn{3}{|c|}{$\begin{array}{l}\gamma \text {-diversity } \\
\left(\mathrm{R}^{2}=0.46\right)\end{array}$} & \multicolumn{3}{|c|}{$\begin{array}{l}\gamma \text {-diversity } \\
\left(\mathrm{R}^{2}=0.41\right)\end{array}$} \\
\hline MANAG & 1 & 287.8 & $5.7 *$ & - & - & n.s. & - & - & n.s. \\
\hline SQ & 1 & 320.5 & $6.3^{*}$ & 1 & 6.8 & 0.2 & 1 & 1.4 & 0.2 \\
\hline SLOPE & - & - & n.s. & 1 & 209.1 & $5.4^{*}$ & 1 & 42.0 & $5.5^{*}$ \\
\hline $\mathrm{N}$ & 1 & 818.2 & $16.1^{* * *}$ & 1 & 566.9 & $14.7 * * *$ & 1 & 100.5 & $13.2 * * *$ \\
\hline $\mathrm{MANAG} \times \mathrm{SQ}$ & 1 & 264.6 & $5.2^{*}$ & - & - & - & - & - & - \\
\hline $\mathrm{SQ} \times \mathrm{SLOPE}$ & - & - & - & 1 & 190.0 & $4.9^{*}$ & 1 & 39.9 & $5.2^{*}$ \\
\hline Residual & 55 & 50.7 & & 55 & 38.6 & & 55 & 7.6 & \\
\hline
\end{tabular}

However, the management regime had a significant effect and the $\gamma$-diversity of all plant species was negatively related to increased soil quality for both meadows and pastures (Fig. 4). The main 
difference between the diversity components of all plant species and forb species was that the first was related to the management regime and the latter was more strongly related to abiotic environmental factors such as soil quality and slope.
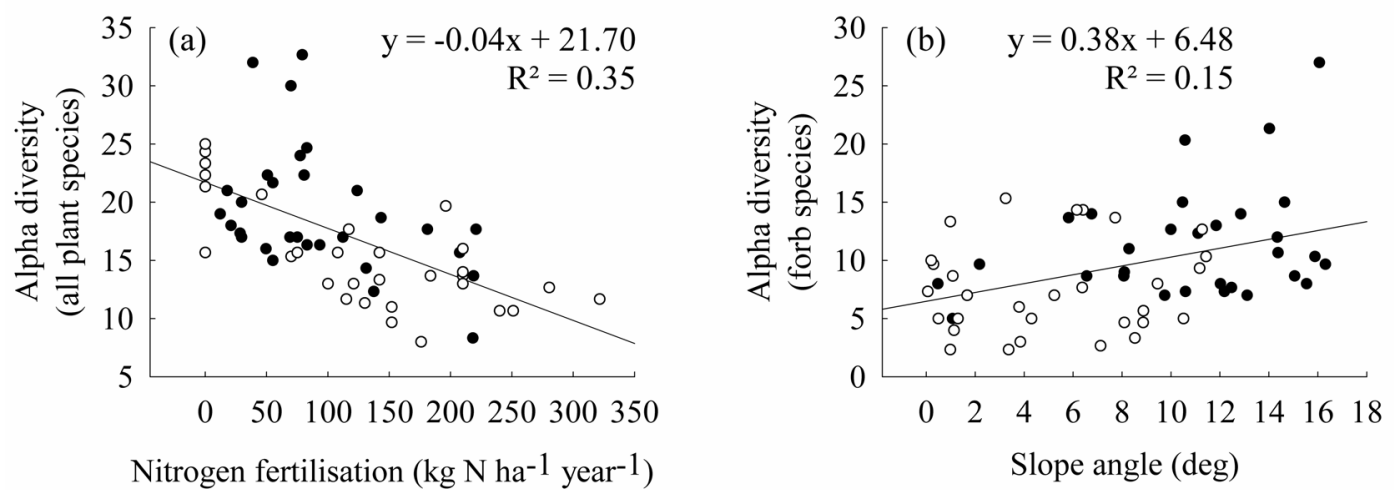

Fig. 2. Scatterplot with linear regression line of (a) the $\alpha$-diversity of all plant species at the field scale against nitrogen fertilisation, and of (b) the $\alpha$-diversity of forb species at the field scale against slope angle. Mown meadows are represented by open circles and grazed pastures by filled circles.

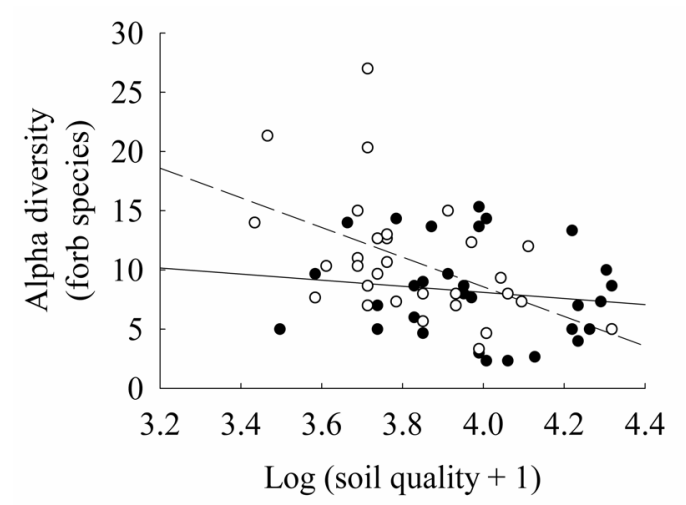

Fig. 3. Illustrating the interacting effects of $\log$ transformed soil quality and slope angle on the $\alpha$ diversity of forb species by use of scatterplots with linear regression lines. Grassland parcels are classified by slope angle. The relationship between soil quality and the $\alpha$-diversity of forb species in grassland parcels situated on 'low slopes' (Minimum $=0.06^{\circ}$, Maximum $=8.09^{\circ}, n=30$; filled circles and solid regression line), and in grassland parcels situated on 'steep slopes' (Minimum $=8.28^{\circ}$, Maximum $=16.31^{\circ}, n=30$; open circles and dashed regression line) are shown. 


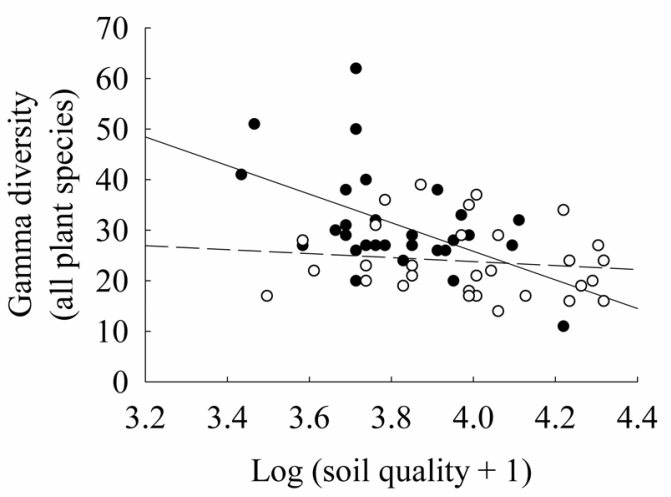

Fig. 4. Scatterplots with linear regression lines of the $\gamma$-diversity of all plant species against log transformed soil quality under each of the two management regimes. Mown meadows are represented by open circles with a dashed regression line and grazed pastures by filled circles with a solid regression line.

\section{Additive partitioning of indicator species}

In all 60 grassland parcels, we found a total regional $\gamma$-diversity of 44 indicator species, 42 of which were forbs and two were grasses (see the Appendix). Within the mown meadows, 24 indicator species (solely forb species) were recorded, and in grazed pastures 42 indicator species were recorded (40 forbs and two grasses). Nearly half of the indicator species (20 indicator species) occurred only in pastures, whereas two indicator species were only found in meadows. At the field scale, the $\alpha-, \beta$-, and $\gamma$-diversity of indicator species were significantly higher in pastures than in meadows (Table 2). Similar to the patterns ascertained for all and forb plant species, the $\beta$-diversity among meadows and pastures at the regional scale made the greatest contribution to the observed regional $\gamma$-diversity of indicator species (21.9 and 37.3 species, respectively; Fig. 1).

The $\alpha$ - and $\gamma$-diversity of all plant species was indicated well by the selected indicator species (Fig. 5). To correct for autocorrelation, we subtracted the indictor species from the corresponding diversity component of all plant species. The linear regression analyses were repeated by replacing the corrected $\alpha$ - and $\gamma$-diversity of all plant species by the non-corrected diversity components and the goodness-of-fit of models increased for both models $\left(\mathrm{R}^{2}=0.68\right.$ and $\mathrm{R}^{2}=0.77$; respectively). In general, the $\alpha$-, $\beta$-, and $\gamma$-diversity of indicator species responded more strongly to the influence of the abiotic environmental covariates soil quality and slope than was observed for diversity components of all plant species (Table 3). Similar to the results obtained for the diversity 
components of forb species, the factor management regime was not significantly related to the $\alpha-, \beta$ , and $\gamma$-diversity of indicator species.

In summary, the diversity components of forb and indicator species showed nearly similar responses to the analysed environmental and management variables, while the management regime was not significant at $P<0.05$. The ANCOVA models for the diversity components of all plant species, by contrast, showed a significant effect of the management regime, but a non-significant effect of slope.
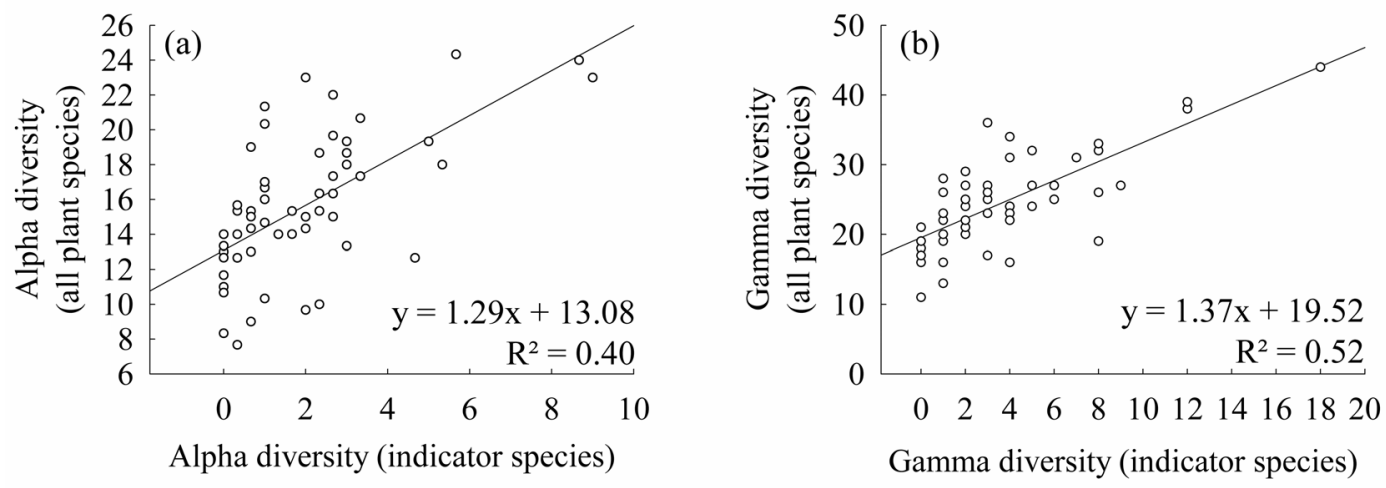

Fig. 5. Scatterplot with linear regression line of (a) the $\alpha$-diversity of all plant species at the field scale against the $\alpha$-diversity of indicator species at the field scale, and of (b) the $\gamma$-diversity of all plant species at the field scale against the $\gamma$-diversity of indicator species at the field scale. The diversity components of all plant species were corrected for autocorrelation by subtracting the indicator species.

\section{Discussion}

In this study, we identified the focal spatial scales at which plant species diversity occurred using the additive partitioning approach. Since all diversity components at both spatial scales were measured in the same units (Wagner et al., 2000), the contributions of $\alpha$ - and - $\beta$-diversity components to the total regional species richness could be directly compared. Although the comparison of mowing and grazing management at two spatial scale levels indicated that plant species richness benefited from low-to-moderate intensity livestock-grazing, this study showed that the processes that determined these relationships were rather based on differing abiotic environmental conditions between management regimes. Our results revealed that for both management regimes the $\beta$-diversity at the regional scale contributed most to the overall observed 
regional $\gamma$-diversity (proportions ranged from 80 to 91\%). Similar results were obtained by Roschewitz et al. (2005), showing that overall diversity of arable weeds was strongly determined by the heterogeneity between the fields ( $\beta$-diversity). In accordance with our results, a study of Gering et al. (2003) on the partitioning of insect diversity across multiple spatial scales indicated that the total species richness was to a large extent attributable to $\beta$-diversity between ecoregions. In this context, Loreau (2000) suggested that the between-unit diversity ( $\beta$-diversity) at each scale was the result of both environmental heterogeneity in space, time or food resources and niche differences among species.

Determinants of species diversity components of all plant species and forb species

At both the local field and the regional scale, the $\alpha-, \beta-$, and $\gamma$-diversity of all plant species and forb species was much higher in grazed pastures than in mown meadows. However, the processes that generated these local-regional patterns of species richness differed between all plant species and forb species. Contrary to the diversity components of forb species, the $\alpha$-diversity of all plant species was positively affected by grazing management regime. There is evidence that grazing animals can alter grassland vegetation by creating heterogeneity in the soil and sward structure through selective grazing, trampling, deposition of excreta (Adler et al., 2001; Rook et al., 2004), and by acting as dispersal agents (Fischer et al., 1996). These small-scale disturbances in the soil and the sward structure have been suggested to promote plant species richness by enabling species establishment through vegetation gaps (Collins et al., 1998; Olff \& Ritchie, 1998). However, our results showed that the positive effect due to grazing management was only valid for the $\alpha$-diversity of all plant species, whereas the $\beta$ - and $\gamma$-diversity of all plant species were related to the interaction of management regime and soil quality, indicating that the response to soil quality was significantly different between mowing and grazing management. In this study, the abiotic environmental variable soil quality reflects the long-term soil nutrient conditions for agricultural production (Rothkegel, 1952). Generally, species-rich grassland communities depend on soils with a low nutrient status (Fuller, 1987). For example, analyses of Critchley et al. (2002) showed that grasslands of high botanical value were related to low concentrations of soil extractable $\mathrm{P}$ and $\mathrm{K}$. The results of the present study revealed that in contrast to the diversity components of all plant species, the $\alpha$ - and $\gamma$-diversity of forb species were strongly associated with the mean slope angle of the grassland parcels. Particularly grazed grassland parcels situated on steeply sloping grounds with poor soil quality showed a positive effect on the species diversity components. Steeper slopes with poor or thin soils are characterised by extreme microclimatological conditions (Bennie et al., 2006; 
Pykälä et al., 2005) that may increase forb species diversity by enabling less competitive plant species to co-exist.

In addition to abiotic environmental variables, local field management intensity, expressed by the amount of nitrogen fertilisation applied, showed a strong negative effect on species diversity components in all models. It is important to stress that the nitrogen application rate is used as a general indicator of management intensity in this study, as the contents of $\mathrm{P}$ and $\mathrm{K}$ in fertilisers were correlated with the $\mathrm{N}$ content and therefore excluded from the analyses. Increased productivity due to high nitrogen application rates lead to a decline in species richness because the sward is dominated by a few competitive species, whereas less competitive sub-dominant species were excluded (Grime, 1973; Plantureux et al., 2005). As shown in a study of Jacquemyn et al. (2003), much of the lower species richness due to application of nitrogen fertilisers could be attributed to a decrease in light availability resulting from high growth rates of tall forbs and grass species.

As our findings clearly showed significant differences in mean values of the abiotic environmental variables soil quality and slope angle between mowing and grazing management, it can de assumed that these abiotic site characteristics determine the spatial distribution of the management regimes within the study region. Thus, areas with unfavourable site characteristics, such as steep slopes, were mainly utilised by grazing management regime, whereas cutting for silage was the most favourable management regime on the more productive soils. In accordance with a study of White et al. (2004), our findings therefore emphasise the need to promote a functionally diverse plant community over the entire managed area, since particularly the heterogeneity between the grassland parcels contributed most to the overall regional diversity.

\section{Determinants of species diversity components of indicator species}

Total richness of indicator species was predominantly explained by $\beta$-diversity at the regional scale. Thus, environmental heterogeneity associated with a great variation of plant communities contributed most to the regional diversity. Nearly half of the indicator species were solely found in grazed pastures, which underline the importance of large scale pasture systems within the study region. In principle, the local-regional patterns of species richness observed for indicators correspond with our findings ascertained for forb species.

Total plant species richness was indicated well by the selected indicators, supporting the usefulness of indicator species for identifying species-rich grassland parcels within the regional context of this study. According to Pearman et al. (2006), the identification of species to serve as indicators could broaden accessory benefits obtained by directing limited floristic resources toward 
their conservation. Thus, to help prioritise conservation efforts within the study area the application of indicator species may be used as an instrument for grassland conservation planning.

\section{Conclusions and management implications}

In conclusion, both low application rates of nitrogen fertilisers and abiotic environmental conditions such as soils with a low nutrient status and steep slopes positively affected vascular plant species richness in temperate managed grasslands. Although the management regime did not show the dominant effect in explaining local-regional patterns of species richness, low-to-moderate livestock grazing contributed indirectly to a high species richness as pastures were mainly located on steeply sloping grounds with poor soil quality. Our findings clearly emphasised that the $\beta$-diversity among grassland parcels contributed most to the total observed species richness in both management regimes. Consequently, the maintenance of a large variety of grassland utilisation systems can allow the conservation of a wide diversity of grassland plants. Particularly, the maintenance of grazing along with a spatially varied disturbance regime at large areas with heterogeneous abiotic environmental conditions (Dullinger et al., 2003) could facilitate successful management of vascular plant species diversity. However, nowadays the maintenance or re-establishment of low-tomoderate mowing and grazing systems can only be enabled, if farmers receive adequate compensation payments against intensification by means of agri-environment subsidies, or when economic drivers towards intensification can not operate (Hodgson et al., 2005). Thus, to prevent further habitat and species loss due to intensification along with abandonment of marginal areas, it is necessary that agri-environment schemes maintain the large-scale distribution of different grassland utilisation systems. Indeed, the importance of agri-environment schemes for the continuation of farming on de-intensified and on unimproved species-rich grasslands has been suggested to increase in the future (Rounsevell et al., 2005).

\section{Acknowledgements}

We thank all farmers for giving permission to work on their fields. Statistical advice of Joachim Saborowski and Dominik Cullmann helped to improve the manuscript. Many thanks to Anne Richter gen. Kemmermann and Elke Bertke for the permission to use the plant species data and Jürgen Böhner for help in handling the large raster datasets. Finally, we would like to thank Nicole Wrage for her constructive comments. This research is part of the BIOPLEX project (Biodiversity and spatial complexity in agricultural landscapes under global change) funded by the German 
Federal Ministry of Education and Research (BMBF). L.M. was in receipt of a grant of the Aldo Gini foundation, Italy. 


\section{References}

Adler, P.B., Raff, D.A. \& Lauenroth, W.K. (2001). The effect of grazing on the spatial heterogeneity of vegetation. Oecologia, 128, 465-479.

Allen, V.G. (1991). Terminology for grazing lands and grazing animals. Pocahontas Press, Blacksbury, Virginia.

Bennie, J., Hill, M.O., Baxter, R. \& Huntley, B. (2006). Influence of slope and aspect on long-term vegetation change in British chalk grasslands. Journal of Ecology, 94, 355-368.

Benton, T.G., Vickery, J.A. \& Wilson, J.D. (2003). Farmland biodiversity: Is habitat heterogeneity the key? Trends in Ecology and Evolution, 4, 182-188.

Collins, S.L., Knapp, A.K., Briggs, J.M., Blair, J.M. \& Steinauer, E.M. (1998). Modulation of diversity by grazing and mowing in native tallgrass prairie. Science, 280, 745-747.

Collins, S.L., Glenn, S.M. \& Briggs, J.M. (2002). Effects of local and regional processes on plant species richness in tallgrass prairie. Oikos, 99, 571-579.

Crawley, M. J. (2002). Statistical computing. An introduction to data analysis using S-Plus. John Wiley and Sons, Chichester, UK.

Critchley, C.N.R., Chambers, B.J., Fowbert, J.A., Sanderson, R.A., Bhogal, A. \& Rose, S.C., (2002). Association between lowland grassland plant communities and soil properties. Biological Conservation, 105, 199-215.

Donald, P.F. \& Evans, A.D. (2006). Habitat connectivity and matrix restoration: the wider implications of agri-environment schemes. Journal of Applied Ecology, 43, 209-218.

Duelli, P. \& Obrist, M.K. (1998). In search of the best correlates for local organismal biodiversity in cultivated areas. Biodiversity and Conservation, 7, 297-309.

Dullinger S., Dirnbock T., Greimler J. \& Grabherr G. (2003). A resampling approach for evaluating effects of pasture abandonment on subalpine plant species diversity. Journal of Vegetation Science, 14, 243-252.

Duru M. \& Hubert B. (2003). Management of grazing systems: from decision and biophysical models to principles for action. Agronomie, 23, 689-703.

Fischer, S., Poschlod, P. \& Beinlich, B. (1996). Experimental studies on the dispersal of plants and animals by sheep in calcareous grasslands. Journal of Applied Ecology, 33, 1206-1222.

Fuller, R.M. (1987). The changing extent and conservation interest of lowland grasslands in England and Wales: a review of grassland surveys 1930-84. Biological Conservation, 40, 281300. 
Garcia, A. (1992). Conserving the species-rich meadows of Europe. Agriculture, Ecosystems and Environment, 40, 219-232.

Gering, J.C., Crist, T.O. \& Veech, J.A. (2003). Additive partitioning of species diversity across multiple spatial scales: implications for regional conservation of biodiversity. Conservation Biology, 17, 488-499.

Grace, J.B. (1999). The factors controlling species density in herbaceous plant communities: an assessment. Perspectives in Plant Ecology Evolution and Systematics, 2, 1-28.

Grime, J.P. (1973). Competitive exclusion in herbaceous vegetation. Nature, 242, 344-347.

Grime, J.P. (2001). Plant strategies, vegetation processes, and ecosystem properties. 2nd ed., Wiley, Chichester, UK.

Helm, A., Hanski, I. \& Pärtel, M. (2006). Slow response of plant species richness to habitat loss and fragmentation. Ecology Letters, 9, 72-77.

Hodgson, J.G., Montserrat-Martí, G., Tallowin, J., Thompson, K., Díaz, S., Cabido, M., Grime, J.P, Wilson, P.J., Band, S.R., Bogard, A., Cabido, R., Cáceres, D., Castro-Díez, P., Ferrer, C. et al. (2005). How much will it cost to save grassland diversity? Biological Conservation, 122, 263273.

Jacquemyn, H., Brys, R. \& Hermy, M. (2003). Short-time effects of different management regimes on the response of calcareous grassland vegetation to increased nitrogen. Biological Conservation, 111, 137-147.

Jongman, R.H.G. (2002). Homogenisation and fragmentation of the European landscape: ecological consequences and solutions. Landscape and Urban Planning, 58, 211-221.

Kiviniemi, K. \& Eriksson, O. (2002). Size-related deterioration of semi-natural grassland fragments in Sweden. Diversity and Distributions, 8, 21-29.

Kleijn, D., Berendse, F., Smit, R. \& Gilissen, N. (2001). Agri-environment schemes do not effectively protect biodiversity in Dutch agricultural landscapes. Nature, 413, 723-725.

Kleijn, D., Baquero, R.A., Clough, Y., Díaz, M., De Esteban, J., Fernández, F., Gabriel, D., Herzog, F., Holzschuh, A., Jöhl, R., Knop, E., Kruess, A., Marshall, E.J.P., Steffan-Dewenter, I., Tscharntke, T., Verhulst, J., West, T.M. \& Yela, J.L. (2006). Mixed biodiversity benefits of agrienvironment schemes in five European countries. Ecology Letters, 9, 243-254.

Lande, R. (1996). Statistics and partitioning of species diversity, and similarity among multiple communities. Oikos, 76, 5-13.

Legendre, P. \& Legendre, L. (1998). Numerical Ecology, 2nd English Edition. Elsevier Science BV, Amsterdam. 
Loreau, M. (2000). Are communities saturated? On the relationship between $\alpha, \beta$ and $\gamma$ diversity. Ecology Letters, 3, 73-76.

Magurran, A.E. (2004). Measuring biological diversity. Blackwell Publishing, Oxford, UK.

Martin, L.M., Moloney, K.A. \& Wilsey, B.J. (2005). An assessment of grassland restoration success using species diversity components. Journal of Applied Ecology, 42, 327-336.

Moog, D., Poschlod, P., Kahmen, S. \& Schreiber, K.-F. (2002). Comparison of species composition between different grassland management treatments after 25 years. Applied Vegetation Science, 5, 99-106.

Münzbergová, Z. (2004). Effect of spatial scale on factors limiting species distributions in dry grassland fragments. Journal of Ecology, 92, 854-867.

Myklestad, Å. \& Sætersdal, M. (2004). The importance of traditional meadow management techniques for conservation of vascular plant species richness in Norway. Biological Conservation, 118, 133-139.

Nösberger, J. \& Rodriguez, M. (1996). Increasing biodiversity through management. Grassland Science in Europe, 1, 949-956.

Oberdorfer, E. \& Müller, T. (1993). Süddeutsche Pflanzengesellschaften. Teil 3, Wirtschaftswiesen und Unkrautgesellschaften. Fischer, Jena, Germany.

Olff, H. \& Ritchie, M.E. (1998). Effects of herbivores on grassland plant diversity. Trends in Ecology and Evolution, 13, 261-265.

Opitz von Boberfeld, W. (1994). Grünlandlehre - biologische und ökologische Grundlagen. Ulmer, Stuttgart, Germany.

Oppermann, R. \& Briemle, G. (2004). Von der Idee zum Programm: Die Förderung artenreichen Grünlandes in Baden-Württemberg in MEKA II. In Artenreiches Grünland bewerten und fördern - MEKA und ÖQV in der Praxis, ed. R. Oppermann, H.-U. Gujer, Ulmer, Stuttgart, pp. 26-32.

Pärtel, M., Zobel, M., Zobel, K. \& van der Maarel, E. (1996). The species pool and its relation to species richness: evidence from Estonian plant communities. Oikos, 75, 111-117.

Pearman, P.B., Penskar M.R., Schools E.H. \& Enander H.D. (2006). Identifying potential indicators of conservation value using natural heritage occurrence data. Ecological Applications, 16, 186201.

Plantureux, S., Peeters, A. \& McCracken, D. (2005). Biodiversity in intensive grasslands: Effect of management, improvement and challenges. Agronomy Research, 3, 153-164. 
Poschlod, P., Tackenberg, O. \& Bonn, S. (2005). Plant dispersal potential and its relation to species frequency and co-existence. In: van der Maarel, E. (Ed.), Vegetation Ecology. Blackwell Science Ltd, USA, pp. 147-171.

Pykälä, J., Luoto, M., Heikkinen, R.K. \& Kontula, T. (2005). Plant species richness and persistence of rare plants in abandoned semi-natural grasslands in northern Europe. Basic and Applied Ecology, 6, 25-33.

Quinn, G.P. \& Keough, M.J. (2002). Experimental Design and Data Analysis for Biologists. Cambridge University Press.

Ricklefs, R.E. (1987). Community diversity: relative roles of local and regional processes. Science, 235, 167-171.

Rook, A.J., Dumont, B., Isselstein, J., Osoro, K., WallisDeVries, M.F., Parente G. \& Mills, J. (2004). Matching type of livestock to desired biodiversity outcomes in pastures - a review. Biological Conservation, 119, 137-150.

Roschewitz, I., Gabriel, D., Tscharntke, T. \& Thies, C. (2005). The effects of landscape complexity on arable weed species diversity in organic and conventional farming. Journal of Applied Ecology, 42, 873-882.

Rothkegel, W. (1952). Landwirtschaftliche Schätzungslehre. Ulmer, Stuttgart, Germany.

Rounsevell, M.D.A., Ewert, F., Reginster, I., Leemans, R. \& Carter, T.R. (2005). Future scenarios of European agricultural land use - II. Projecting changes in cropland and grassland. Agriculture, Ecosystems \& Environment, 107, 117-135.

Smith, R.S., Buckingham, H., Bullard, M.J., Shiel, R.S. \& Younger, A. (1996). The conservation management of mesotrophic (meadow) grassland in Northern England. I. Effects of grazing, cutting and fertiliser on the vegetation of a traditionally managed sward. Grass and Forage Science, 51, 278-291.

Söderström, B., Svensson, B., Vessby, K. \& Glimskär, A. (2001). Plants, insects and birds in seminatural pastures in relation to local habitat and landscape factors. Biodiversity and Conservation, 10, 1839-1863.

Sokal, R.R. \& Rohlf, F.J. (1995). Biometry: The Principles of Statistics in Biological Research. 3rd ed. W.H. Freeman, New York, NY.

Tscharntke, T., Klein, A.-M., Kruess, A., Steffan-Dewenter, I. \& Thies, C. (2005). Landscape perspectives on agricultural intensification and biodiversity - ecosystem service management. Ecology Letters, 8, 857-874. 
Veech, J.A., Summerville, K.S., Crist, T.O. \& Gering, J.C. (2002). The additive partitioning of species diversity: A recent revival of an old idea. Oikos, 99, 3-9.

Vickery, J.A., Bradbury, R.B., Henderson, I.G., Eaton, M.A. \& Grice, P.V. (2004). The role of agrienvironment schemes and farm management practices in reversing the decline of farmland birds in England. Biological Conservation, 119, 19-39.

Wagner, H.H., Wildi, O. \& Ewald, K.C. (2000). Additive partitioning of plant species diversity in an agricultural mosaic landscape. Landscape Ecology, 15, 219-227.

WallisDeVries, M.F., Poschlod, P. \& Willems, J.H. (2002). Challenges for the conservation of calcareous grasslands in northwestern Europe: integrating the requirements of flora and fauna. Biological Conservation, 104, 265-273.

Walther, U., Menzi, H., Ryser, J.-P., Flisch, R., Jeangros, B., Maillard, A., Siegenthaler, A., \& Vuilloud, P.A. (1994). Grundlagen für die Düngung im Acker- und Futterbau. Agrarforschung, $1,1-40$.

White T.A., Barker, D.J. \& Kenneth, J.M. (2004). Vegetation diversity, growth, quality and decomposition in managed grasslands. Agriculture, Ecosystems and Environment, 101, 73-84.

Wisskirchen, R. \& Haeupler, H. (1998). Standardliste der Farn- und Blütenpflanzen Deutschlands. Ulmer, Stuttgart, Germany.

Wittig, B, Richter gen. Kemmermann, A. \& Zacharias, D. (2006). An indicator species approach for result-orientated subsidies of ecological services in grasslands - A study in Northwestern Germany. Biological Conservation, 133, 186-197.

Zechmeister, H.G., Schmitzberger, I., Steurer, B., Peterseil, J. \& Wrbka, T. (2003). The influence of land-use practices and economics on plant species richness in meadows. Biological Conservation, 114, 165-177. 
Appendix Abundance (number of parcels, in which each indicator species occurred) of indicator species in 60 grassland parcels.

\begin{tabular}{|c|c|c|c|}
\hline Species name & $\begin{array}{l}\text { Abundance } \\
\text { (60 Grassland parcels) }\end{array}$ & $\begin{array}{l}\text { Abundance } \\
\text { (30 Meadows) }\end{array}$ & $\begin{array}{l}\text { Abundance } \\
\text { (30 Pastures) }\end{array}$ \\
\hline \multicolumn{4}{|l|}{ Forbs } \\
\hline Achillea ptarmica & 2 & 1 & 1 \\
\hline Alchemilla vulgaris & 8 & 2 & 6 \\
\hline Bistorta officinalis & 2 & - & 2 \\
\hline Caltha palustris & 2 & 1 & 1 \\
\hline Cardamine pratensis & 20 & 13 & 7 \\
\hline Cirsium acaule & 1 & - & 1 \\
\hline Cirsium oleraceum & 1 & 1 & - \\
\hline Crepis biennis & 13 & 1 & 12 \\
\hline Crepis capillaries & 2 & - & 2 \\
\hline Crepis paludosa & 1 & - & 1 \\
\hline Filipendula ulmaria & 4 & 3 & 1 \\
\hline Galium saxatile & 2 & - & 2 \\
\hline Geranium dissectum & 9 & 1 & 8 \\
\hline Geranium molle & 8 & 5 & 3 \\
\hline Geranium pusillum & 12 & 4 & 8 \\
\hline Geranium robertianum & 1 & - & 1 \\
\hline Hieracium lactucella & 1 & - & 1 \\
\hline Hieracium pilosella & 2 & - & 2 \\
\hline Hypericum maculatum & 2 & 1 & 1 \\
\hline Hypericum perforatum & 4 & 1 & 3 \\
\hline Hypochaeris radicata & 1 & - & 1 \\
\hline Lathyrus pratensis & 7 & 2 & 5 \\
\hline Leontodon autumnalis & 4 & - & 4 \\
\hline Lotus corniculatus & 3 & - & 3 \\
\hline Lotus pedunculatus & 1 & - & 1 \\
\hline Lysimachia nummularia & 7 & 6 & 1 \\
\hline Medicago lupulina & 4 & 1 & 3 \\
\hline Myosotis scorpioides & 1 & - & 1 \\
\hline Pimpinella major & 2 & - & 2 \\
\hline Pimpinella saxifraga & 3 & - & 3 \\
\hline Plantago media & 1 & 1 & - \\
\hline Potentilla erecta & 1 & - & 1 \\
\hline Ranunculus acris & 21 & 4 & 17 \\
\hline Sanguisorba minor & 1 & - & 1 \\
\hline Silene flos-cuculi & 4 & 2 & 2 \\
\hline Stellaria graminea & 11 & 2 & 9 \\
\hline Tragopogon pratensis & 2 & 1 & 1 \\
\hline Trifolium campestre & 8 & 2 & 6 \\
\hline Trifolium dubium & 6 & 2 & 4 \\
\hline Vicia hirsute & 2 & - & 2 \\
\hline Vicia sepium & 6 & 4 & 2 \\
\hline Vicia tetrasperma & 5 & 1 & 4 \\
\hline
\end{tabular}




\begin{tabular}{llll}
\hline Species name & $\begin{array}{l}\text { Abundance } \\
\text { (60 Grassland parcels) }\end{array}$ & $\begin{array}{l}\text { Abundance } \\
\text { (30 Meadows) }\end{array}$ & $\begin{array}{l}\text { Abundance } \\
\text { (30 Pastures) }\end{array}$ \\
\hline Grasses & & & \\
Luzula campestris & 3 & - & 3 \\
Nardus stricta & 1 & - & 1 \\
\hline
\end{tabular}




\section{CHAPTER}

Effects of local factors on plant species richness and composition of Alpine meadows

Lorenzo Marini, Michele Scotton, Sebastian Klimek, Johannes Isselstein \& Angelo Pecile

In: Agriculture, Ecosystems \& Environment (in press) 


\begin{abstract}
The determinants of plant species richness and composition of meadows are often mutually related, showing joint effects on plant diversity. Thus, the specific objective of this paper was to evaluate the relative importance of soil, topography, and field management explanatory variables on plant species richness and composition of mown meadows in an area of the Southern Alps. The data consisted of 159 taxa sampled during the summer of 2003 in $5610 \times 10 \mathrm{~m}^{2}$ sampling plots. For each plot, 25 explanatory variables were recorded. The variation in species richness and composition was divided into the three sets of explanatory variables using a variation partitioning method. Species richness was mostly controlled both by the short-term effect nitrogen fertilisation, and, as stressed by studies in other landscape contexts in Europe, by the long-term effect of soil phosphorus accumulation. The decrease of plant species number on the most fertile meadows was the consequence of the dominance of few competitors or ruderals, which prevented the establishment of small stress-tolerant species. In contrast to species richness, plant species composition presented important pure effect of topography (altitude and slope). Species composition depended on several topography, soil, and field management factors. Thus, for both conservation and restoration of species-rich hay meadows, it is necessary to maintain a low level of soil $\mathrm{P}$ content, and to prevent the abandonment of parcels on steep slopes and in marginal areas, because these hosted the highest level of plant diversity.
\end{abstract}

Keywords: biodiversity conservation, management, phosphorus, soil, topography, variation partitioning 


\section{Introduction}

In EU, agri-environment schemes have been established to support the non-production function of grasslands. However, these schemes are mainly not well targeted. They do not adequately consider the different management systems and the diversity of the local flora, and tend to increase the homogeneity of the agricultural environment. They have been demonstrated to not effectively enhance plant diversity (Kleijn and Sutherland, 2003). In order to improve the efficiency of management measures in future agri-environment schemes, it is necessary to understand the relative importance of the main determinants affecting plant diversity in grasslands.

Species richness and composition of vascular plants in grasslands are predominantly controlled by local factors, and only secondarily by factors operating at the landscape-scale (Wright et al., 2003). Grasslands are strongly affected by field management: it has frequently been shown that the application of high doses of fertilisers and intensive sward utilization have negative effects on plant species diversity (e.g. Garcia, 1992; Myklestad and Sætersdal, 2004). Chemical and physical soil properties are related to natural soil characteristics, but also to fertilisation inputs, and influence both species richness and species composition of vascular plants (Myklestad, 2004). In particular, it is well established that the phosphorus $(\mathrm{P})$ soil content is an important determinant for the reconstruction or conservation of species-rich meadows (Janssens et al., 1998; Tracy and Sanderson, 2000; Critchley et al., 2002a). Other studies have shown that abiotic environmental factors such as topographic or climatic parameters can be important sources of variation of plant diversity, because the occurrence of many grassland species is governed by microclimatological characteristics (Sebastiá, 2004; Bennie et al., 2006).

The determinants of plant species richness and composition of meadows are often mutually related, showing joint effects on plant diversity. As there is a general lack of information about the relative importance of these factors in grasslands, the specific objective of this paper is to explore the relative effect of soil, topography, and field management explanatory variables on species richness and composition of mown meadows in an area of the Southern Alps. We hypothesised that 1) species richness was mostly controlled both by the short-term effect of nitrogen $(\mathrm{N})$ fertilisation (Jacquemyn et al., 2003), and, as stressed by studies in other landscape contexts in Europe (Janssens et al., 1998; Critchley et al., 2002a), by the long-term effect of soil P accumulation; 2) species composition depended strongly not only on soil fertility and field management, but also on topography due to the highly variable Alpine environment, and 3) the decrease of the number of plant species on the most fertile meadows was the consequence of the dominance of few species 
(Schwab et al., 2002), which prevented the establishment of small stress-tolerant plants. To test these hypotheses, we used a variation partitioning method, which is a statistical approach to evaluate the relative effect of different sets of explanatory variables on diversity patterns.

\section{Materials and methods}

The study area was located in Primiero and Vanoi $\left(46^{\circ} 04^{\prime}-46^{\circ} 13^{\prime} \mathrm{N} ; 11^{\circ} 34^{\prime}-11^{\circ} 52^{\prime}\right.$ E), the southeastern district of the Trento province, NE Italy (Fig. 1). The geology was heterogeneous with calcareous, siliceous bedrocks and mixed sediments. The climate was humid with a mean rainfall of $1200 \mathrm{~mm} \mathrm{yr}^{-1}$. The mean temperature at the minimum considered altitude (610 m a.s.1.) was 9-10 ${ }^{\circ} \mathrm{C}$, while it was $4.5-5.5^{\circ} \mathrm{C}$ at the maximum altitude (1440 m a.s.1.).

With a preliminary strictly vegetation analysis, four hay meadow communities could be identified in the study area: 1) lowland moderate intensive meadows (Pastinaco-Arrhenatheretum); 2) lowland high intensive meadows (Ranunculo repentis-Alopecuretum pratensis), 3) mountain intensive meadows (Trisetetum flavescentis), and 4) semi-natural extensive low productive meadows (Bromion erecti). Within each of the first three vegetation types, 15 meadows were randomly selected, while for 4) only 11 were chosen (Fig. 1). The 56 meadows considered in the study belonged to 15 different farms. The phytosociological nomenclature follows Mucina et al. (1993), while the nomenclature of the vascular plants is according to Wisskirchen and Haeupler (1998).
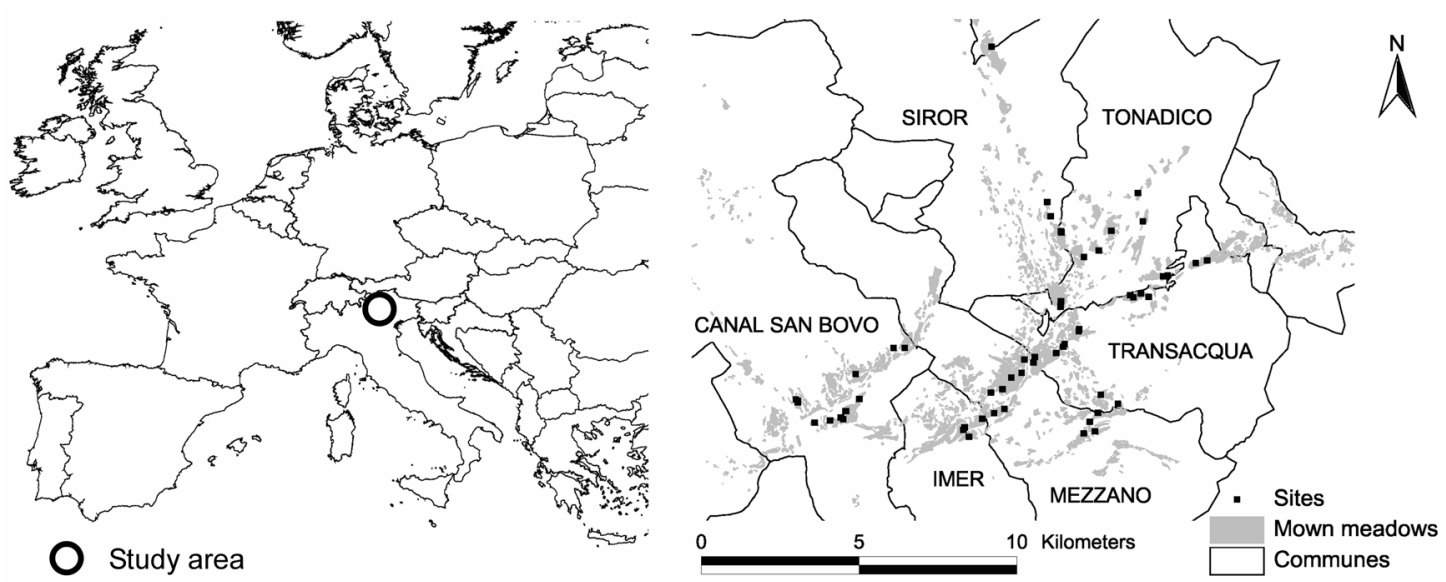

Fig. 1 Location of the 56 investigated grassland sites within the study area.

Hay meadows were fertilised in spring and autumn with farmyard manure or liquid manure, and grazed for only a few days in autumn. Rarely, mineral fertiliser was applied once between the cuts 
as N-P-K ternary fertilisers (mostly 20-10-10) or ammonium nitrate (34-0-0). The range of variation in usually applied fertilisation input was $0-350 \mathrm{~kg} \mathrm{~N} \mathrm{ha}^{-1} \mathrm{yr}^{-1}$. The meadows with the lowest level of fertilisation $\left(<50 \mathrm{~kg} \mathrm{~N} \mathrm{ha}^{-1} \mathrm{yr}^{-1}\right)$ produced on average $3.5 \mathrm{t}$ dry matter $\mathrm{ha}^{-1} \mathrm{yr}^{-1}$, while the sites with the highest level $\left(>250 \mathrm{~kg} \mathrm{~N} \mathrm{ha}^{-1} \mathrm{yr}^{-1}\right)$ had a yield of ca. $8.5 \mathrm{t}$ dry matter $\mathrm{ha}^{-1} \mathrm{yr}^{-1}$. These yields were calculated by harvesting the biomass on 33 parcels (average of two strips of $0.1 \times 10 \mathrm{~m}^{2}$ for each meadow). The cutting frequency varied from 1 to 3 cuts per year (rarely 4) depending on altitude and intensity of fertilisation.

In each selected meadow, a square of $10 \times 10 \mathrm{~m}^{2}$ was randomly established. Edge effects were avoided by excluding a 10-m buffer zone from the field boundaries. For each plot, a complete floristic survey was carried out before the first cut using the van der Maarel (1979) abundance estimation scale. Species richness was estimated two times per site, once before the first cut and once before the second.

For all sites, 25 explanatory variables were recorded: 16 soil (S), 5 topography (T), and 4 field management variables (M) (Table 1). In each plot, a composite soil sample was collected during the week from 20th to 26th of August 2003. The samples were taken at a depth of 0-20 cm, after removing the organic layer, and were composed of four cores with a diameter of $12 \mathrm{~cm}$ taken at each of the four corners of the plot. The soil cores were bulked prior to analyses. Soil $\mathrm{pH}$ (measured in water), total phosphorus (aqua regia-ICPMS), total potassium (aqua regia-ICPMS), Kjeldahl total nitrogen, exchangeable magnesium (ammonium acetate extraction), Olsen phosphorus, exchangeable potassium (ammonium acetate extraction), $\mathrm{CaO}_{3}$ (gas-volumetric determination of $\mathrm{CO}_{2}$ with $\mathrm{HCl}$ ), Organic Matter (Springer-Klee method), and Cation Exchange Capacity (method with barium chloride triethanolamine) were measured using the Italian standard soil analysis techniques (G.U., 1999). The topographic variables were calculated on the basis of a digital elevation model with a cell size of $10 \times 10 \mathrm{~m}^{2}$. The following quantitative explanatory variables were measured on all plots using SAGA GIS Version 2.1 (available at http://www.saga-gis.org/): elevation, slope, mean precipitation in June (1990-2003), sum of solar radiation in May, and Topographical Wetness Index (Beven and Kirkby, 1979). The radiation was calculated using a constant for atmospheric transmittance of $60 \%$ and a solar constant of 1367 . The mean precipitation was retrieved from Sboarina and Cescatti (2004). Field management variables (applied fertilisers and cutting frequency) were obtained from interviews using a standardized questionnaire. The total amount of $\mathrm{N}$ fertilisers was calculated by summing up organic and mineral $\mathrm{N}$. The concentration of $\mathrm{N}$ for the different organic fertilisers was retrieved from Walther et al. (1994). 
Prior to analyses, some explanatory variables ( $\mathrm{P}_{\text {Olsen }}$ and $\mathrm{N}_{-}$FERT $)$were log-transformed to improve the linearity of the relations. All the other variables showed linear relations with species richness.

Table 1 Descriptive statistics of the 25 explanatory variables used in the variation partitioning procedure for plant species richness and composition of 56 mown meadows in the Italian Alps.

\begin{tabular}{|c|c|c|c|c|c|}
\hline $\begin{array}{l}\text { Variables }^{\mathrm{a}} \\
\text { Soil (S) }\end{array}$ & Description and units $^{\mathrm{b}}$ & MEAN & SD & MIN & MAX \\
\hline [SAND 2.0] & $0.5<$ sand fraction $<2.0 \mathrm{~mm}\left(\mathrm{~g} \mathrm{~kg}^{-1}\right)$ & 187.4 & 73.3 & 39.0 & 374.0 \\
\hline [SAND_0.5] & $0.25<$ sand fraction $<0.5 \mathrm{~mm}\left(\mathrm{~g} \mathrm{~kg}^{-1}\right)$ & 89.8 & 31.4 & 43.0 & 176.0 \\
\hline SAND_0.25 & $0.05<$ sand fraction $<0.25 \mathrm{~mm}\left(\mathrm{~g} \mathrm{~kg}^{-1}\right)$ & 211.7 & 84.7 & 6.0 & 460.0 \\
\hline$[\mathrm{SILT}]$ & $0.002<$ silt fraction $<0.05 \mathrm{~mm}\left(\mathrm{~g} \mathrm{~kg}^{-1}\right)$ & 448.8 & 116.0 & 179.0 & 679.0 \\
\hline CLAY & clay fraction $<0.002 \mathrm{~mm}\left(\mathrm{~g} \mathrm{~kg}^{-1}\right)$ & 61.0 & 30.9 & 10.0 & 180.0 \\
\hline $\mathrm{pH}$ & $\mathrm{pH}$ measured in water & 6.0 & 0.7 & 4.9 & 7.3 \\
\hline$\left[\mathrm{CaCO}_{3}\right]$ & content of $\mathrm{CaCO}_{3}\left(\mathrm{~g} \mathrm{~kg}^{-1}\right)$ & 35.6 & 69.7 & 1.0 & 375.0 \\
\hline O.M. & Organic Matter $\left(\mathrm{g} \mathrm{kg}^{-1}\right)$ & 95.6 & 31.6 & 45.0 & 191.0 \\
\hline P_tot & total phosphorus $\left(\mathrm{g} \mathrm{kg}^{-1}\right)$ & 1.0 & 0.4 & 0.5 & 2.7 \\
\hline K_tot & total potassium $\left(\mathrm{g} \mathrm{kg}^{-1}\right)$ & 3.9 & 1.3 & 1.4 & 7.2 \\
\hline$[\overline{\mathrm{N}}]$ & Kjeldahl total nitrogen $\left(\mathrm{g} \mathrm{kg}^{-1}\right)$ & 5.8 & 1.9 & 1.0 & 12.3 \\
\hline $\mathrm{P}_{\text {Olsen }}$ & Olsen $\mathrm{P}_{2} \mathrm{O}_{5}\left(\mathrm{mg} \mathrm{kg}^{-1}\right)$ & 46.9 & 31.7 & 13.0 & 155.0 \\
\hline K_ex & exchangeable potassium $\left(\mathrm{mg} \mathrm{kg}^{-1}\right)$ & 173.7 & 105.3 & 48.0 & 504.0 \\
\hline$\overline{\mathrm{Mg}}$ ex & exchangeable magnesium $\left(\mathrm{mg} \mathrm{kg}^{-1}\right)$ & 988.7 & 525.4 & 317.0 & 2838.0 \\
\hline$[\mathrm{CEC}]$ & Cation Exchange Capacity $\left(\mathrm{mEq} \mathrm{kg}{ }^{-1}\right)$ & 3.1 & 1.0 & 1.5 & 6.7 \\
\hline SOIL D & soil depth $(\mathrm{cm})$ & 34.3 & 17.1 & 8.0 & 70.0 \\
\hline \multicolumn{6}{|c|}{ Topography (T) } \\
\hline ALTIT & altitude (m a.s.l.) & 946.3 & 248.4 & 610.9 & 1442.5 \\
\hline SLOPE & slope $(\%)$ & 13.8 & 11.3 & 0.0 & 44.5 \\
\hline PREC & mean precipitation of June (mm) & 136.0 & 5.6 & 127.4 & 154.6 \\
\hline RAD & sum solar radiation of May $\left(\mathrm{kWh} \mathrm{m}^{-2}\right)$ & 234.0 & 6.0 & 215.9 & 243.8 \\
\hline WET & Topographical Wetness Index & 8.7 & 2.2 & 5.5 & 17.4 \\
\hline \multicolumn{6}{|c|}{ Field management (M) } \\
\hline$\overline{\text { CUTS }}$ & number of cuts $\mathrm{yr}^{-1}$ & 2.3 & 0.6 & 1.0 & 4.0 \\
\hline N_FERT & total nitrogen fertilisers $\left(\mathrm{kg} \mathrm{N} \mathrm{ha}^{-1} \mathrm{yr}\right.$ & 99.1 & 65.7 & 0.0 & 350.0 \\
\hline N_FERT_M & mineral nitrogen fertilisers $\left(\mathrm{kg} \mathrm{N} \mathrm{ha}{ }^{-1} \mathrm{yr}^{-1}\right)$ & 1.3 & 5.94 & 0.0 & 37.5 \\
\hline$[\overline{\mathrm{N}}$ FERT $\mathrm{T} \mathrm{O}]$ & organic nitrogen fertilisers $\left(\mathrm{kg} \mathrm{N} \mathrm{ha}^{-1} \mathrm{yr}^{-1}\right)$ & 97.8 & 66.1 & 0.0 & 350.0 \\
\hline
\end{tabular}

${ }^{a}$ Intercorrelated variables excluded after the analysis of the Pearson correlation matrix are presented in square parentheses.

${ }^{\mathrm{b}}$ All the soil contents are referred to kg of dry soil.

A possible weak point of variation partitioning is caused by the potential collinearity between explanatory variables within each group of variables (Heikkinen et al., 2005). This problem can produce misleading inferences when the analysis has an explanatory approach for developing new 
insights (MacNally, 2000). Therefore, each of the three sets of explanatory variables was reduced to a smaller number of partially independent factors using their Pearson correlation coefficients. In case of highly correlated variables (Pearson correlation coefficient $>0.6$ ), only one of them was used in the model. The excluded variables are presented in Table 1 in square parentheses. The response vector for species richness consisted of the cumulative number of species encountered in each plot with the two visits. In the species composition model, the response matrix included the abundance of the species quantified before the first cut. Species with a frequency smaller than $3 \%$ in the 56 plots were excluded prior to the analyses.

As a first step, within each set of explanatory variables, we used a separate stepwise forward procedure to select the significant variables (at $\mathrm{P}<0.05$ ) that maximally accounted for variation in each response matrix. Next, the total variation explained by the two models was divided into the three groups of explanatory variables: soil (S), topography (T), and field management (M), using a series of partial Redundancy Analyses (partial RDAs), as implemented in CANOCO version 4.5 (ter Braak and Šmilauer, 2002). RDA is an extension of Principal Component Analysis, in which the canonical vectors are linear combinations both of the response and explanatory variables (Legendre and Legendre, 1998). All analyses were tested with a Monte Carlo Permutation Test with 999 permutations. The method of variation partitioning followed Liu and Bråkenhielm (1995). The method splits the total variation explained into seven fractions: three pure effects of the singular set ( $\mathrm{S}, \mathrm{T}$ and $\mathrm{M}$ ), three shared effects of each pair of sets $(\mathrm{S} \cap \mathrm{T}, \mathrm{S} \cap \mathrm{M}$, and $\mathrm{T} \cap \mathrm{M})$, and the shared effect of the three sets $(\mathrm{S} \cap \mathrm{T} \cap \mathrm{M})$. The shared fractions express the joint effect of different groups of variables that can not be attributed to one group only. Since the shared effects were obtained by subtraction, they could not be tested for significance (Legendre and Legendre, 1998).

As explanatory variables were not mutually independent, variation partitioning can help determine the amount of variation related to independent and shared effects, and clarify the relative influence of the sets of variables considered (Heikinnen et al., 2005).

Furthermore, the species were classified using the $\mathrm{C}$ (competitor), $\mathrm{S}$ (stress-tolerant), and $\mathrm{R}$ (ruderal) plant functional types (Grime, 2001) according to Hodgson et al. (1999). For each survey, a functional signature was derived using the Excel spreadsheet-based tool proposed by Hunt et al. (2004). This C-S-R signature is a three-part index that indicates the proportion of the three strategies in a community. The sum of the three values is set to 1 . We computed simple linear regressions between species richness and the single C-, S-, and R- components. 


\section{Results}

Plant species richness and composition were affected in a different manner by soil, topography and management factors (Table 2). The number of significant variables entering the multiple regression models after the separate stepwise forward selections was four and seven for species richness and composition, respectively. In the model of species richness, $\mathrm{P}_{\text {Olsen }}$ was the only significant soil variable with a negative effect on the response variable. The relation we found between $\mathrm{P}$ and species richness was curvilinear as demonstrated in several studies in other landscape contexts in Europe (Janssens et al., 1998; Tracy and Sanderson, 2000; Critchley, 2002a).

Table 2 Results of the stepwise forward selection of the explanatory variables in the multiple regression models of plant species richness and composition for soil (S), topography (T) and field management (M) components. The data were obtained from 56 mown meadows in the Italian Alps.

\begin{tabular}{|c|c|c|c|c|c|c|c|c|}
\hline \multicolumn{3}{|c|}{ Soil model (S) } & \multicolumn{3}{|c|}{ Topography model (T) } & \multicolumn{3}{|c|}{ Management model (M) } \\
\hline Variable & $\mathrm{p}$ & $\mathrm{R}^{2}$ & Variable & $\mathrm{p}$ & $\mathrm{R}^{2}$ & Variable & $\mathrm{p}$ & $\mathrm{R}^{2}$ \\
\hline \multicolumn{9}{|c|}{ Plant species richness } \\
\hline $\mathrm{P}_{\text {Olsen }}(-)$ & \multicolumn{2}{|l|}{0.001} & \multicolumn{3}{|c|}{ SLOPE (+) 0.001} & \multicolumn{3}{|c|}{ N_FERT (-) 0.025} \\
\hline model & & 45.0 & model & & 31.9 & $\begin{array}{l}\text { CUTS (-) } \\
\text { model }\end{array}$ & 0.001 & 47.0 \\
\hline \multicolumn{9}{|c|}{ Plant species composition } \\
\hline $\mathrm{P}_{\text {Olsen }}$ & 0.001 & & ALTIT & 0.001 & & CUTS & 0.001 & \\
\hline $\mathrm{pH}$ & 0.044 & & SLOPE & 0.002 & & N_FERT & 0.021 & \\
\hline CLAY & 0.004 & & & & & & & \\
\hline model & & 17.1 & model & & 16.6 & model & & 14.6 \\
\hline
\end{tabular}

For each model, the total variation explained $\left(\mathrm{R}^{2}\right.$, equivalent to the sum of all the canonical eigenvalues) is given. Directions of associations (- or + ) and the P-values (Monte Carlo Permutation test, $\mathrm{n}=999)$ for significant variables $(\mathrm{P}<0.05)$ are presented. See Table 1 for abbreviations of variables names.

Among the topographic variables, only slope was significantly positively related to species richness. The field management model indicated that cutting frequency and nitrogen fertilisation affected species richness negatively. As $\mathrm{P}_{\text {Olsen }}$, N_FERT presented a curvilinear relation with the number of vascular plant species. In the regression model of species composition, the significant soil variables were: $\mathrm{P}_{\text {Olsen }}, \mathrm{pH}$, and clay fraction. Significant topographic variables were altitude and slope, indicating that elevation affected species composition but not the number of species. The field management variables were the same as for species richness. The variation explained 
separately by each single set was composed of a pure effect, and shared effects with the other groups (Liu and Bråkenhielm, 1995).

In the variation partitioning of species richness, the total variation explained was $60.7 \%$, indicating that the chosen variables explained a large amount of the total variation (Table 3 ). The pure effects of soil and of field management components were relatively large, while the pure effect of topography was not significant. The joint effects of topography, management and soil $(\mathrm{S} \cap \mathrm{T} \cap \mathrm{M})$, and of soil and field management $(\mathrm{S} \cap \mathrm{M})$ were the most important components. The model of species composition with all significant variables of the three groups together accounted for $32.6 \%$ of the total variation (Table 3).

Table 3 Variation partitioning of plant species richness and composition into soil (S), topography (T) and field management (M) components $\left(\mathrm{R}^{2}\right.$ in \%). The data were obtained from 56 mown meadows in the Italian Alps.

\begin{tabular}{|c|c|c|c|c|c|c|c|}
\hline \multicolumn{2}{|c|}{ Pure effects } & \multicolumn{4}{|c|}{ Shared effects } & \multicolumn{2}{|r|}{$\overline{T_{V E}}$} \\
\hline $\mathrm{S}$ & $\mathrm{T}$ & M & $\mathrm{S} \cap \mathrm{T}$ & $\mathrm{S} \cap \mathrm{M}$ & $\mathrm{T} \cap \mathrm{M}$ & $\mathrm{S} \cap \mathrm{T} \cap \mathrm{M}$ & \\
\hline \multicolumn{8}{|c|}{ Plant species richness } \\
\hline 9.0 & 2.4 & 7.4 & 2.3 & 12.4 & 5.9 & 21.3 & 60.7 \\
\hline \multicolumn{8}{|c|}{ Plant species composition } \\
\hline 10.5 & 7.6 & 4.4 & -0.1 & 1.1 & 3.5 & 5.6 & 32.6 \\
\hline
\end{tabular}

The P-values of the pure effects and of the total model with all variables are given in brackets (Monte Carlo Permutation test, $\mathrm{n}=999$ ).

${ }^{a}$ TVE.: total variation explained.

Of the pure components, the soil was again the most important component, but the pure topography component gained in importance in explaining species composition, contrasting to species richness. The two shared fractions of topography and management were also relatively important.

The response of the 28 species with a fit-range above $20 \%$ to the seven significant variables is presented as an RDA biplot (Fig. 2). The first axis accounted for $15.0 \%$ of the total variation and separated most species based on a gradient of management intensity and topography. Intensive lowland hay meadows with a high level of nitrogen fertilisation and cutting frequency were dominated by tall-growing grasses, as Alopecurus pratensis or Poa trivialis, and by competitive forbs, as Anthriscus sylvestris and Rumex sp.pl. In less intensive meadows on steeper slopes, mostly stress-tolerant grasses and forbs with a low growth-rate were found: e.g. Festuca rupicola and 
Trifolium montanum. On the plots at higher altitudes, there was a well-defined group of species typical of the mountain level: e.g. Rumex arifolius and Trollius europaeus differentiated these meadows from those at lower altitudes. The second axis was less important, capturing only $5.6 \%$ of the total variation, and dividing the species mainly according to the clay fraction, and further according to altitude and slope.

The simple regression models between species richness and C-, S-, and R-components of the functional signature showed significant results. The highest species richness was found in plots with high values of the S-component and with low values of the C- and R-components (Fig. 3). The Scomponent regression model indicated a strong positive relation between high species richness and the presence of small stress-tolerant species, while the presence of ruderals and competitors had a negative effect. The $\mathrm{C}$ - and R- components were not significantly correlated.

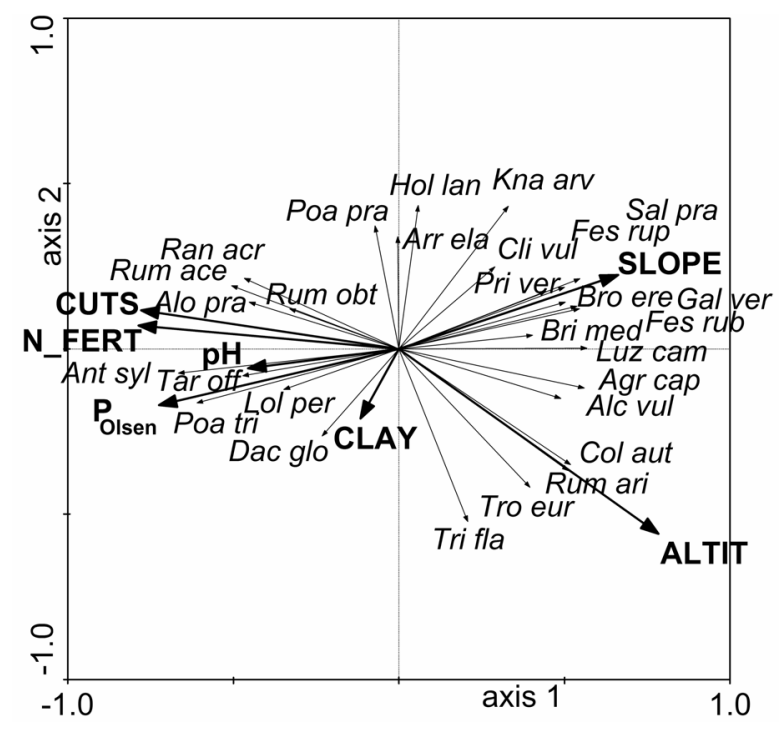

Fig. 2 Ordination plot of vascular plant species and explanatory variables along the first two axes of RDA constrained with the seven significant variables of the variation partitioning model. Only those 28 species with a fit-range above $20 \%$ are shown. The axes are scaled in standard deviation units. The data were obtained from 56 mown meadows in the Italians Alps. See Table 1 for abbreviations of variables names. Abbreviations of species' names: Agr cap:_Agrostis capillaris; Alc vul: Alchemilla vulgaris agg.; Alo pra: Alopecurus pratensis; Ant syl: Anthriscus sylvestris; Arr ela: Arrhenatherum elatius; Bri med: Briza media; Bro ere: Bromus erectus; Cli vul: Clinopodium vulgare; Col aut: Colchicum autumnale; Dac glo: Dactylis glomerata; Fes rub: Festuca rubra agg.; Fes rup: Festuca rupicola; Gal ver: Galium verum; Hol lan: Holcus lanatus; Kna arv: 
Knautia arvensis; Lol per: Lolium perenne; Luz cam: Luzula campestris; Poa pra: Poa pratensis; Poa tri: Poa trivialis; Pri ver: Primula veris; Ran acr: Ranunculus acris; Rum ace: Rumex acetosa; Rum ari: Rumex arifolius; Rum obt: Rumex obtusifolius; Sal pra: Salvia pratensis; Tar off: Taraxacum officinale Sect. Ruderalia; Tri fla: Trisetum flavescens; Tro eur: Trollius europaeus.

\section{Discussion}

The results suggest that plant species richness and species composition responded in a different manner to the considered determinants. In line with our first hypothesis, species richness depended mainly on the long-term effect of field management intensity, expressed by the soil P content, as well as on the short-term effect due to $\mathrm{N}$ fertilisers. The pure soil component explained more variation than the pure management. However, it has to be kept in mind that the measured soil chemical variables were linked not only to the natural fertility of the site, but also to long-term management inputs. Similar relationships between species richness, soil and management were found by several authors (e.g. Schellberg et al., 1999; Myklestad, 2004). The large P content in the more fertilised soils was probably caused by the low removal of $\mathrm{P}$ with harvested forage in comparison to the inputs. As demonstrated by Ekholm et al. (2005), most of the P surplus tends to accumulate in the soil in stable forms that can only relatively slowly be transported to surface waters. Our results demonstrated that $\mathrm{P}_{\text {Olsen }}$ has been shown to be a key factor determining the number of species. Willems and van Nieuwstadt (1996) demonstrated that the increase of species richness after the cessation of fertilisation was slower in P-rich soils than in N-rich ones, confirming the long-term effect of this element. In our study, only one plot with a $\mathrm{P}_{\text {Olsen }}$ content larger than 60 $\mathrm{mg} \mathrm{kg}^{-1}$ contained more than 26 species per $100 \mathrm{~m}^{2}$. Furthermore, no plot with a content larger than $25 \mathrm{mg} \mathrm{kg}^{-1}$ had more than 40 species per $100 \mathrm{~m}^{2}$.

The important pure effect of field management demonstrated that soil was not solely explaining species richness. $\mathrm{N}$ pools are usually more dynamic in soil so that the $\mathrm{N}$ fertilisers can affect species richness only in the short-term after their applications (Jacquemyn et al., 2003). The $\mathrm{N}$ fertilisers variable must be considered as an indicator of the total input of nutrients. In fact, potassium $(\mathrm{K})$ and $\mathrm{P}$ in fertilisers were excluded from the study because they were highly correlated with $\mathrm{N}$ due to the prevalence of organic fertilisation. 


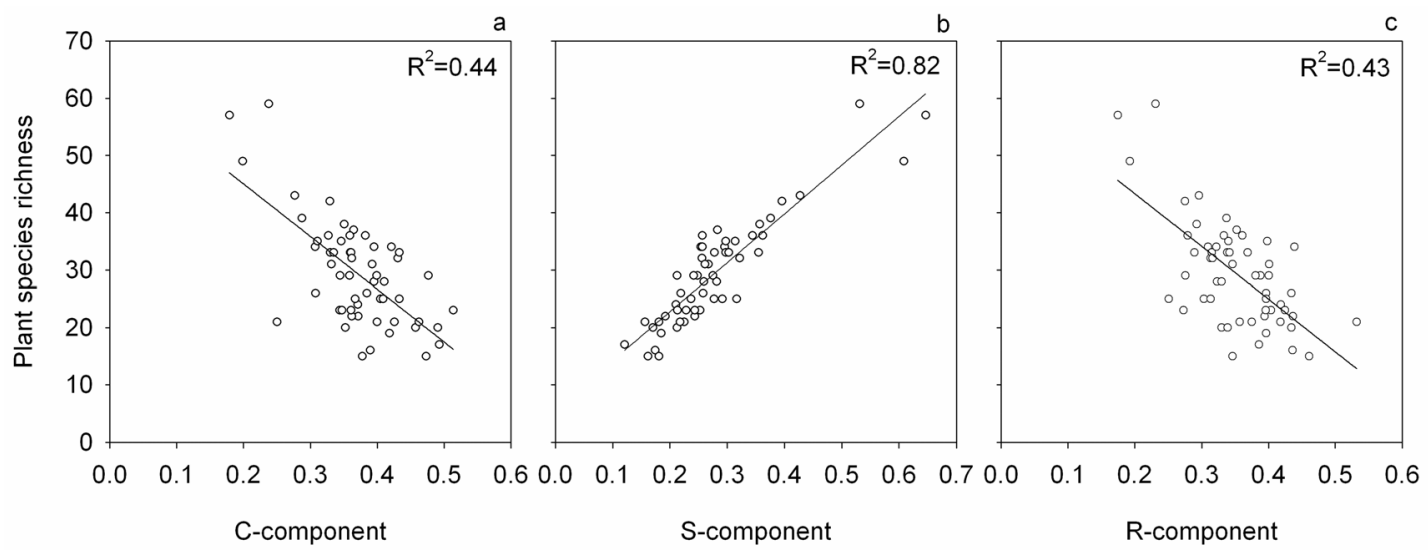

Fig. 3 Simple linear regressions of plant species richness versus a) C-component, b) S-component, and c) R-component of the functional signature according to Hunt el al. (2004). The data were obtained from 56 mown meadows in the Italian Alps. All regressions were significant at $\mathrm{P}<0.01$ (Ftest).

Despite the correlation between $\mathrm{N}, \mathrm{P}$ and $\mathrm{K}$ in fertilisers, their distribution pattern in soil is obviously different. When the P content (total and Olsen) was excluded from the analyses, total $\mathrm{N}$ did still not become significant. In contrast to $\mathrm{P}$, the soil $\mathrm{N}$ content was not correlated with the application of fertilisers, because it is quickly transformed and very dynamic in soil, and because it can be renewed from other important sources such as atmospheric deposition, organic matter mineralization, and $\mathrm{N}$ fixation. Without $\mathrm{P}_{\text {Olsen, }}$ exchangeable $\mathrm{K}$ became significant but had a weaker explanatory power, indicating that moderately large $\mathrm{K}$ contents were compatible with high species numbers. The plots with the highest level of diversity were those with an exchangeable $\mathrm{K}$ content of $120-140 \mathrm{mg} \mathrm{kg}^{-1}$. K has a rather high mobility in soil, but leaching losses are small compared to plant uptake, which represents the major sink in the K budget (e.g. Kayser and Isselstein, 2005). Thus, the weaker relation between exchangeable $\mathrm{K}$ and species richness was probably due to the removal of the herbage and to mobility of $\mathrm{K}$.

The positive relation between increasing slope and species numbers was probably caused by different field management practices. This may be a consequence of the behaviour of the farmers, who managed the most accessible, less steep sites more intensively. Therefore, the relation between topography and species richness was due to a joint effect with field management and soil, and not to an independent effect. The altitude had not a significant effect on species number. In fact, species richness did not differ between the sites located on high altitude compared to the low-altitude ones. 
According to our second hypothesis, species composition was affected not only by soil fertility but also by topography probably due to the high variability of the Alpine environments. As demonstrated by several authors (e.g. Snow et al., 1997; Critchley et al., 2002b; Myklestad, 2004), $\mathrm{P}_{\text {Olsen }}$ is a key factor explaining the variation of species composition. Topography is also a main driver due to the strong effect of altitude and slope on temperature, and consequently on the length of the growing season, confirming that the occurrence of many grassland species is governed by microclimatological characteristics (Sebastiá, 2004; Bennie et al., 2006). Several variables had to be included in the model, most of them presenting an equivalent marginal contribution. The variation of the floristic composition along the fertility gradient indicated the negative effect of soil $\mathrm{P}$ and $\mathrm{N}$ fertilisers on the presence of stress-tolerant species, which are normally those with the major conservationist interest (Prosser, 2001).

The regression between species richness and the C-, S-, and R- components indicated that the decrease of species richness in fertile plots was probably caused by the dominance of species with C- and R- strategies, confirming our third hypothesis that high $\mathrm{N}$ and $\mathrm{P}$ availability determined low species richness resulting from the dominance of a few competitors and ruderals. The ability of large, fast-growing perennial herbs to suppress the growth of smaller neighbours was particularly evident in the studied vegetation types. Both a reduction in species richness and an increasing dominance of few species are a common phenomenon in highly fertilised grasslands (Berendse and Elberse, 1990). P-limited meadows showed the coexistence of many individuals of different taxa, due to the presence of stress-tolerant species with low potential growth-rates, and small stature.

In conclusion, both field management and soil fertility were main determinants of vascular plant species richness, while for species composition topography gained in importance. Thus, for both conservation and restoration of species-rich hay meadows, it is necessary to maintain a low level of soil P content (in our study beneath a threshold of $60 \mathrm{mg} \mathrm{kg}^{-1}$ ) and to prevent the abandonment of parcels on steep slopes and in marginal areas, because these hosted the highest level of plant diversity.

\section{Acknowledgements}

We thank M. Hofmann (Sächsische Landesanstalt für Landwirtschaft, Pöhl - D) for her helpful suggestions and N. Wrage (University of Goettingen - D) for improving the English. We are grateful to P. Rodaro for carrying out the floristic and management surveys, and to M. Anesi for his support with the field work. We wish to thank also the Editor and two anonymous referees for their useful comments and suggestions that improved this paper. This research has been financially 
supported by the Agricultural Institute of San Michele all'Adige (IASMA), and by the Aldo Gini Foundation. GIS data were provided by the Agriculture Department of Trento Province. 


\section{References}

Bennie, J., Hill, M.O., Baxter, R., Huntley, B., 2006. Influence of slope and aspect on long-term vegetation change in British chalk grasslands. J. Ecol. 94, 355-368.

Berendse, F., Elberse, W.T., 1990. Competition and nutrient availability in heathland and grassland ecosystems. In: Grace, B., Tilman, D. (Eds.), Perspective on Plant Competition. Academic Press, London, pp. 93-116.

Beven, K.J., Kirkby, M.J., 1979. A physically based variable contributing area model of basin hydrology. Hydrological Science Bullettin 24, 43-69.

Critchley, C.N.R., Chambers, B.J., Fowbert, J.A., Bhogal, A., Rose, S.C., Sanderson, R.A., 2002a. Plant species richness, functional type and soil properties of grasslands and allied vegetation in English Environmentally Sensitive Areas. Grass Forage Sci. 57, 82-92.

Critchley, C.N.R., Chambers, B.J., Fowbert, J.A., Sanderson, R.A., Bhogal, A., Rose, S.C., 2002 b. Association between lowland grassland plant communities and soil properties. Biol. Conserv. $105,199-215$.

Ekholm, P., Turtola, E., Grönroos, Seuri, P., Ylivainio, K., 2005. Phosphorus loss from different farming systems estimated from soil surface phosphorus balance. Agric. Ecosyst. Environ. 110. 266-278.

Garcia, A., 1992. Conserving the species-rich meadows of Europe. Agric. Ecosyst. Environ. 40, 219-232.

Grime, J.P., 2001. Plant strategies, vegetation processes, and ecosystems properties, 2nd ed. John Wiley \& Sons, Chichester.

G.U. (Gazzetta Ufficiale dello Stato Italiano), 1999. Approval: Metodi ufficiali di analisi fisica del suolo. D.M., 13th September 1999, suppl. G.U., 248, 21th October 1999.

Heikkinen, R.K., Luoto, M., Kuussaari, M., Pöyry, J., 2005. New insights into butterflyenvironment relationships using partitioning methods. Proc. R. Soc. Lond. Ser. B-Biol. Sci. 272, 2203-2210.

Hodgson, J.G., Wilson, P.J., Hunt, R., Grime, J.P., Thompson, K., 1999. Allocating C-S-R plant functional types: a soft approach to a hard problem. Oikos 85, 282-294.

Hunt, R., Hodgson, J.G., Thompson, K., Bungener, P., Dunnett, N.P., Askew, A.P., 2004. A new practical tool for deriving a functional signature for herbaceous vegetation. Appl. Veg. Sci. 7, 163-170. 
Jacquemyn, H., Brys, R., Hermy, M., 2003. Short-time effects of different management regimes on the response of calcareous grassland vegetation to increased nitrogen. Biol. Conserv. 111, 137147.

Janssens, F., Peeters, A., Tallowin, J.R.B., Bakker, R.M., Fillat, F., Oomes, M.J.M., 1998. Relation between soil chemical factors and grasslands diversity. Plant Soil 202, 69-78.

Kayser, M., Isselstein, J., 2005. Potassium cycling and losses in grassland systems: a review. Grass Forage Sci. 60, 213-224.

Kleijn, D., Sutherland, W.J., 2003. How effective are European agri-environment schemes in conserving and promoting biodiversity? J. Appl. Ecol. 40, 947-969.

Legendre, P., Legendre, L., 1998. Numerical Ecology, 2nd English Edition. Elsevier Science BV, Amsterdam.

Liu, Qinghong, Bråkenhielm, S., 1995. A statistical approach to decompose ecological variation. Water Air Soil Poll. 85, 1587-1592.

MacNally, R., 2000. Regression and model-building in conservation biology, biogeography, and ecology: the distinction between - and reconciliation of - 'predictive' and 'explanatory' models. Biodivers. Conserv. 9, 655-671.

Mucina, L., Grabherr, G., Ellmauer, T. (Eds.), 1993. Die Pflanzengesellschaften Österreichs. Gustav Fischer Verlag, Jena.

Myklestad, Å., 2004. Soil, site and management components of variation in species composition of agricultural grasslands in western Norway. Grass Forage Sci. 59, 136-143.

Myklestad, Å., Sætersdal, M., 2004. The importance of traditional meadow management techniques for conservation of vascular plant species richness in Norway. Biol. Conserv. 118, 133-139.

Prosser, F., 2001. Lista rossa della flora del Trentino. Pteridofite e fanerogame. Museo Civico di Rovereto. Edizioni Osiride, Trento.

Sboarina, C., Cescatti, A., 2004. Il clima del Trentino. Distribuzione spaziale delle principali variabili climatiche. Report 33. Centro di Ecologia Alpina, Trento.

Schellberg, J., Möseler, B.M., Kühbauch, W., Rademacher, I.F., 1999. Long-term effect of fertiliser on soil nutrient concentration, yield, forage quality and floristic composition of a hay meadow in the Eifel Mountains, Germany. Grass Forage Sci. 54, 195-207.

Schwab, A., Dubois, D., Fried, P.M., Edwards, P.J., 2002. Estimating the biodiversity of hay meadows in north-eastern Switzerland on the basis of vegetation structure. Agric. Ecosyst. Environ. 93, 197-209. 
Sebastiá, M.T., 2004. Role of topography and soils in grassland structuring at the landscape and community scales. Basic Appl. Ecol. 5, 331-346.

Snow, C.S.R., Marrs, R.H., Merrick, L., 1997. Trends in soil chemistry and floristic associated with the establishment of a low-input meadow system on an arable clay soil in Essex. Biol. Conserv. 79, 35-41.

ter Braak, C.J.F., Šmilauer, P., 2002. CANOCO Reference manual and CanoDraw for Windows User's guide: Software for Canonical Community Ordination (version 4.5). Microcomputer Power, Ithaca.

Tracy, B., Sanderson, M.A., 2000. Patterns of plant species richness in pasture lands of the northeast United States. Plant Ecol. 149, 169-180.

van der Maarel, E., 1979. Transformation of cover-abundance values in phytosociology and its effect on community similarity. Vegetatio 3, 97-114.

Walther, U., Menzi, H., Ryser, J.-P., Flisch, R., Jeangros, B., Maillard, A., Siegenthaler, A., Vuilloud, P.A., 1994. Grundlagen für die Düngung im Acker- und Futterbau. Agrarforschung 1, $1-40$.

Willems, J.H., van Nieuwstadt, M.G.L., 1996. Long-term after effects of fertilization on aboveground phytomass and species diversity in calcareous grassland. J. Veg. Sci. 7, 177-184.

Wisskirchen, R., Haeupler, H., 1998. Standardliste der Farn- und Blütenpflanzen Deutschlands. Ulmer, Stuttgart.

Wright, J.P., Flecker, A., Jones, C.G., 2003. Local vs. landscape controls on plant species richness in beaver meadows. Ecology 84, 3162-3173. 


\section{CHAPTER}

Patterns of plant species density in Alpine hay meadows:

local vs. landscape controls

Michele Scotton, Lorenzo Marini, Sebastian Klimek \& Angelo Pecile

Submitted to Basic and Applied Ecology 


\begin{abstract}
Habitat type and quality are recognised as important local determinants of species richness, but other processes operating at the landscape scale can affect diversity patterns. Scientific evidences regarding the relative importance of landscape context on vascular plants are contrasting, and little is known about the effects of this complex factor in Alpine environments. Hence, the primary purpose of the study was to elucidate the relative effects of plant species density determinants by decomposing the variation into local and landscape components. We sampled ninety-nine hay meadows in the Italian Alps, and recorded twelve explanatory variables belonging to three sets: two sets of local variables, field management and abiotic environment, and a set of landscape variables. Partitioning analyses revealed that species density was affected primarily by local determinants. Species number per area tended to increase in extensively managed meadows, and site conditions such as steep slopes, shallow soils, and increased elevation also contributed to enhance plant species density. Regarding the landscape determinants, a high proportion of urban elements affected species density negatively, while an increased amount of edges had an opposite effect. The landscape context probably operated by influencing the local pool of species that were potentially able to disperse into the sites. Moreover, a relatively high level of urbanisation could possibly cause additional nutrient inputs, not directly related to management, which intensified the detrimental effect of fertilisation. Our results corroborate the hypothesis that even vascular plants, as several animal taxa, are significantly affected by the landscape context, although the local habitat quality explained a greater proportion of the variation in species density.
\end{abstract}

Keywords: biodiversity conservation, grassland management, hierarchical partitioning, nitrogen, topography, urban elements, variation partitioning 


\section{Introduction}

Habitat type and quality are recognised as important local determinants of species richness (Rosenzweig, 1995), but other processes operating at landscape level can affect diversity patterns. At local scale, the actual agricultural exploitation in many European countries affects biodiversity negatively mostly due to intensification and abandonment of low-productive and traditionally managed habitats (Strijker, 2005). At landscape scale, this change in land use has led to a homogenisation of the landscape matrix and to a fragmentation of semi-natural habitats (Tscharntke, Klein, Kruess, Steffan-Dewenter, \& Thies, 2005). Nowadays, two trends of meadow management can be observed in the Alps. The number of traditional farms has decreased, and many marginal sites far from the farms have been abandoned, mostly due to economic reasons (Tasser \& Tappeiner, 2002). The remnant farms, characterised by high stocking rates, are mostly concentrated on the most productive valley soils, and farm enlargement along with land consolidation has led to decreased landscape heterogeneity. Moreover, as the Alps are of great tourist interest, the accompanied urbanisation process continues to occupy new areas in the valleys. Consequences are the development of new plant communities related to high input management and the disappearance of rare vegetation types depending on low- to- moderate intensity (e.g. Scotton, Marini, Pecile, Franchi, \& Fezzi, 2005). Due to this change in land use, in the last decades of the 20th century, a drastic local loss of plant species related to traditionally managed grasslands was observed (e.g. Prosser, 2001).

On the one hand, local grassland characteristics have been demonstrated to be important drivers of species richness due to different field management (Gough, Osenberg, Gross, \& Collins, 2000; Jacquemyn, Brys, \& Hermy, 2003), abiotic environment (Sebastiá, 2004; Bennie, Hill, Baxter, \& Huntley, 2006), and soil characteristics (e.g. Critchley, Chambers, Fowbert, Bhogal, Rose et al., 2002a). At field scale, the long- and short-term effects of high fertiliser applications result in simplified species-poor meadows without conservationist interest (e.g. Critchley, Chambers, Fowbert, Sanderson, Bhogal et al., 2002b). On the other hand, additional processes operating simultaneously at a larger scale can cause variation on local species richness (Whittaker, Willis, \& Field, 2001). It is well established that landscape context has an important effect on species richness of several animal taxonomic groups (e.g. Söderström, Svensson, Vessby, \& Glimskär, 2001; Kleijn \& van Langevelde, 2006). The relevant scales, at which landscape processes potentially affect animal diversity, depend on size, mobility, and functional traits of the different taxa (Tscharntke et al., 2005). Less is known about the influence of the adjoining landscape on sessile organisms as 
vascular plants, and scientific evidences regarding the relative importance of this complex factor are contrasting. For instance, Söderström et al. (2001) and Roschewitz, Gabriel, Tscharntke, \& Thies (2005) demonstrated that plant species richness was generally lower in sites surrounded by a large proportion of arable land, while Weibull, Östman, \& Granqvist (2003) reported that the number of plants was positively affected by small-scale landscape heterogeneity. Other studies stressed a nonsignificant relation with the adjoining landscape (Dauber, Hirsch, Simmering, Waldhardt, Otte et al., 2003; Krauss, Klein, Steffan-Dewenter, \& Tscharntke, 2004). The potential importance of landscape factors on vascular plants of grassland in Alpine environments has still received limited attention. Hence, the primary purpose of the study was to elucidate the determinants of species density in Alpine hay meadows, by decomposing the variation into local and landscape components. Our hypotheses were that 1) plant species density was primarily controlled by local determinants due to the strong effect of field management (Myklestad \& Sætersdal, 2004) and abiotic environment (Bennie et al., 2006), and 2) the surrounding landscape should have a significant effect on species density by influencing the pool of species that were potentially able to arrive at the site (Collins, Glenn, \& Briggs, 2002; Lepš, 2005). To test these hypotheses, we used variation partitioning and hierarchical partitioning in a complementary manner to evaluate the independent contribution of local and landscape determinants in explaining plant species density.

\section{Materials and methods}

\section{Study site}

The research was carried out in five administrative districts of the Trento Province (NE Italy): 1) Low Valsugana and Tesino, 2) High Valsugana, 3) Primiero, 4) Fiemme Valley, and 5) Fassa Valley (Fig. 1). The mean annual rainfall in the area was ca. $1050 \mathrm{~mm}$. The mean annual temperature at the minimum altitude considered $\left(320 \mathrm{~m}\right.$ a.s.1.) was ca. $12{ }^{\circ} \mathrm{C}$, while it was ca. $3.5^{\circ} \mathrm{C}$ at the maximum altitude (1910 m a.s.1.).

The mown meadows in the study area were located mainly in two different landscape contexts due to topography and land use: 1) relatively highly urbanised flat valleys, where the agricultural and dairy farming activities were concentrated; here, the agricultural landscape was characterised by hay meadows, forage cultures, and, in the external valleys, by apple plantations; 2) little urbanised steeper mountain slopes mainly covered by forests, and secondarily by mown meadows. All the investigated meadows were connected with the dairy farming system. 

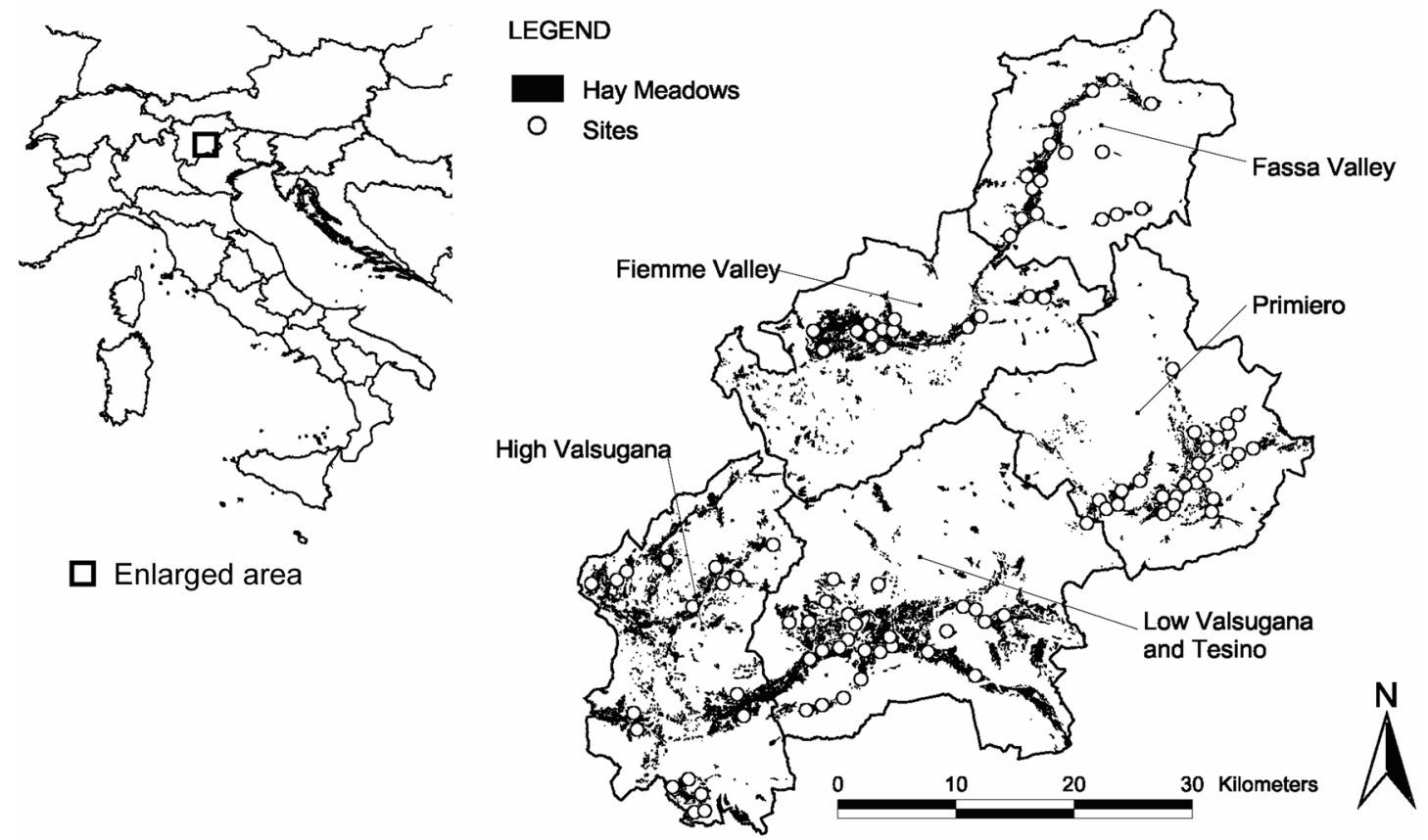

Fig. 1 Location of the study area (WGS 84: N 45 $53^{\prime}-46^{\circ} 32^{\prime}$; E $11^{\circ} 10^{\prime}-11^{\circ} 55^{\prime}$ ) and of the 99 meadow sites in the five administrative districts of the Trento province (NE Italy).

\section{Sampling}

We selected ninety-nine management units from the five districts in close collaboration with the farmers using as selection criterion the characteristics of agricultural management practices in order to sample a large gradient of management intensity. Then, we carried out the floristic, environmental, and landscape surveys. The sites were spatially independent with a minimum distance between the studied parcels of at least $1 \mathrm{~km}$. The management unit area ranged from 0.08 to 3.50 ha. In each selected meadow, a square of $10 \times 10 \mathrm{~m}^{2}$ was randomly established. Edge effects were avoided by excluding a $10-\mathrm{m}$ buffer zone from the management unit boundaries. All the vascular plants in the square were identified at the species level and recorded by visiting the sites once before the first and once before the second cut. In all the analyses, species density was the cumulative number of species per $100 \mathrm{~m}^{2}$ found during the two visits (Gotelli \& Colwell, 2001). The sampled hay meadows covered a wide range of herbaceous mown vegetation, including six hay meadow communities: 1) lowland moderately intensive meadows (Ranunculo bulbosiArrhenatheretum); 2) lowland intensive meadows (Pastinaco-Arrhenatheretum); 3) lowland highly intensive meadows with Lolium multiflorum (Lolietum multiflorae); 4) lowland highly intensive 
meadows dominated by Alopecurus pratensis (Ranunculo repentis-Alopecuretum pratensis), 5) mountain, moderately intensive meadows (Trisetetum flavescentis), and 6) semi-natural extensive meadows (Bromion erecti). The phytosociological nomenclature follows that of Mucina, Grabherr, \& Ellmauer. (1993).

\section{Explanatory variables}

For each meadow, we determined twelve explanatory variables belonging to three different groups: two sets of local variables, field management (M) and abiotic environment (E), and a set of landscape variables (L) (Table 1).

Four field management variables were obtained by interviews with the farmers using a standardized questionnaire. The meadows were cut one to four times per year, and sometimes grazed aftermath for a few days in autumn. The fertilisation was mostly organic and was applied in spring and in autumn, while mineral fertilisers were rarely used once between the cuts as NPK ternary fertilisers (mostly 20-10-10) or ammonium nitrate (34-0-0). The contents of nitrogen $(\mathrm{N})$ in organic fertilisers were retrieved from Walther, Menzi, Ryser, Flisch, Jeangros et al. (1994). As N, phosphorus $(\mathrm{P})$, and potassium $(\mathrm{K})$ in fertilisers were highly correlated (Pearson $>0.9$ ), only the $\mathrm{N}$ content was included in further analyses.

Except for soil depth, the abiotic environmental variables were calculated using SAGA GIS Version 2.0 (available at http://www.saga-gis.org/). The topographical variables, including the solar radiation of May, were calculated using a digital elevation model with a cell size of $10 \times 10 \mathrm{~m}^{2}$. Radiation was calculated using an atmospheric transmittance of $60 \%$ and a solar constant of 1367 . The precipitation data were retrieved from continuous raster-based maps provided from Sboarina $\&$ Cescatti (2004). Soil depth measurements were undertaken in each meadow by digging four holes at the corners of the vegetation square, and calculated by averaging the four measurements.

The landscape variables were derived from a detailed vector-based land use map (Territory Informative Systems of the Trento Province). We defined the following six classes of land use: 1) urban elements (houses, streets, and other urban land uses), 2) grassland and forage cultures, 3) woody cultures (mostly apple), 4) forests, 5) water bodies, and 6) other land uses. The vector-based data were converted to a raster model with a cell size of $10 \times 10 \mathrm{~m}^{2}$. In each meadow, around the geographic centre of the sampling plot, we calculated a circular buffer with a $500 \mathrm{~m}$ radius to quantify the surrounding landscape. This spatial scale was chosen considering that vascular plants are sessile and that for plants landscape processes could operate at this particular spatial scale (Söderström et al., 2001; Tscharntke et al. 2005). Prior to further analyses, we checked the accuracy 
of land use classes within the buffers using aerial photographs to avoid misleading classifications. Then, we processed the buffers with FRAGSTATS Version 3.3 (McGarigal, Cushman, Neel, \& Ene, 2002) to calculate several landscape metrics (Table 1). The selection of the landscape metrics was done by considering solely those variables, which were related to our hypotheses ( $\mathrm{Li} \& \mathrm{Wu}$, 2004).

Table 1 Descriptive statistics of the 12 explanatory variables considered for each of the 99 hay meadows in the Italian Alps.

\begin{tabular}{|c|c|c|c|c|c|c|}
\hline Set & Name & Description and unit & MEAN & SD & MIN & MAX \\
\hline \multirow{4}{*}{  } & Cuts & Number of cuts per year & 2.18 & 0.72 & 1.0 & 4.0 \\
\hline & Fertiliser N & $\begin{array}{l}\text { Total amount of fertiliser } \\
\text { nitrogen }\left(\mathrm{kg} \mathrm{N} \mathrm{ha}^{-1} \mathrm{yr}^{-1}\right)\end{array}$ & 107.4 & 86.8 & 0.0 & 438.9 \\
\hline & Organic $\mathrm{N}^{\mathrm{a}}$ & $\begin{array}{l}\text { Amount of organic fertiliser } \\
\text { nitrogen }\left(\mathrm{kg} \mathrm{N} \mathrm{ha}^{-1} \mathrm{yr}^{-1}\right)\end{array}$ & 96.4 & 81.8 & 0.0 & 350.0 \\
\hline & Mineral N & $\begin{array}{l}\text { Amount of mineral fertiliser } \\
\text { nitrogen }\left(\mathrm{kg} \mathrm{N} \mathrm{ha}^{-1} \mathrm{yr}^{-1}\right)\end{array}$ & 10.9 & 28.2 & 0.0 & 300.0 \\
\hline \multirow{5}{*}{ 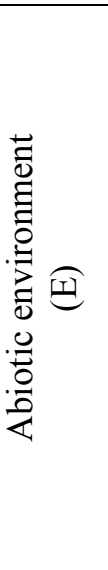 } & Slope & $\begin{array}{l}\text { Mean slope of the } \\
\text { management unit (degree) }\end{array}$ & 7.17 & 6.13 & 0.00 & 28.85 \\
\hline & Elevation & $\begin{array}{l}\text { Mean elevation of the } \\
\text { management unit ( } m \text { a.s.1.) }\end{array}$ & 979.7 & 352.9 & 319.0 & 1910.0 \\
\hline & Radiation & $\begin{array}{l}\text { Cumulative radiation of May } \\
\left(\mathrm{kWh} \mathrm{m}^{-2}\right)\end{array}$ & 176.81 & 10.75 & 140.77 & 199.97 \\
\hline & Precipitation & $\begin{array}{l}\text { Cumulative precipitation of } \\
\text { May, June, July, August and } \\
\text { September (mm) }\end{array}$ & 545.42 & 68.60 & 434.34 & 673.21 \\
\hline & Soil depth & $\begin{array}{l}\text { Mean soil depth } \\
(\mathrm{cm})\end{array}$ & 34.10 & 15.69 & 8.50 & 76.25 \\
\hline \multirow{3}{*}{ 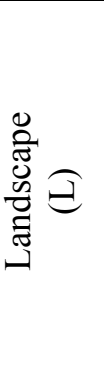 } & Urban elements & $\begin{array}{l}\text { Proportion of urban elements } \\
\text { in a } 500 \mathrm{~m} \text { radius }(\%)\end{array}$ & 11.85 & 11.54 & 0.00 & 45.87 \\
\hline & Forest area & $\begin{array}{l}\text { Proportion of forest area in a } \\
500 \mathrm{~m} \text { radius }(\%)\end{array}$ & 40.09 & 23.82 & 3.66 & 84.61 \\
\hline & Total edges & $\begin{array}{l}\text { Total edges between } \\
\text { meadows and all the other } \\
\text { land use classes in a } 500 \mathrm{~m} \\
\text { radius (m) }\end{array}$ & 8268.5 & 3998.1 & 160 & 21060 \\
\hline
\end{tabular}

Additionally, we took into account the spatial structure of the response variable using a trend surface analysis based on the longitude (X) and latitude (Y) of each site (Legendre \& Legendre, 
1998). The spatial variables were calculated by including all terms for a cubic trend surface regression $\left(\mathrm{X}, \mathrm{Y} ; \mathrm{X}^{2}, \mathrm{Y}^{2}, \mathrm{XY}, \mathrm{X}^{2} \mathrm{Y}, \mathrm{XY}^{2}, \mathrm{X}^{3}, \mathrm{Y}^{3}\right)$. Before the analysis, the coordinates were centred on their respective means to reduce multicollinearity among the terms. The inclusion of this spatial component in the analysis allows incorporating effects caused by other spatially structured variables not taken into consideration.

\section{Data analysis}

First, the relationship of each explanatory variable with species density was individually tested for linearity. Fertiliser $\mathrm{N}$ and urban elements were log-transformed to improve linearity and to achieve a normal distribution of the residuals. After these transformations, all the relations were monotonic. Since multicollinearity among explanatory variables can hamper the identification of the most causal variables (MacNally, 2000), we calculated the Pearson correlation matrix of the variables, and out of every highly correlated pair (Pearson $>0.60$ ), one variable was retained for further analyses. Only two variables were highly correlated: fertiliser $\mathrm{N}$ and organic N. We retained fertiliser $\mathrm{N}$ because it had a better fit with the response variable.

Within each set of variables, a separate forward stepwise procedure was performed to select the significant predictors (enter P-level of 0.05), which most accounted for the variation in species density. As the forward stepwise selection of variables revealed that no spatial variables were significantly related to species density, we did not take the spatial variables into account in further analyses. The significant variables within each set were further analysed to determine the relative influence of field management, abiotic environment, and landscape on species density. As explanatory variables often show joint effects on response variables, variation partitioning can help determine the amount of variation related to the independent and shared contributions, and clarify the relative influence of the sets of variables considered (Heikkinen, Luoto, Kuussaari, \& Pöyry, 2005). The total variation was decomposed into eight components: the pure effect of field management (M), the pure effect of abiotic environment (E), the pure effect of landscape (L), the joint effect of abiotic environment and landscape $(E \cap L)$, the joint effect of field management and environment $(\mathrm{M} \cap \mathrm{E})$, the joint effect of field management and landscape $(\mathrm{M} \cap \mathrm{L})$, the joint effect of the three sets $(\mathrm{M} \cap \mathrm{E} \cap \mathrm{L})$, and the variation unexplained by the variables included in the analysis (Un). The variation partitioning method was carried out using a series of partial Redundancy Analyses (partial RDAs) as implemented in the CANOCO package (Version 4.5; ter Braak \& Šmilauer, 2002). All the partial RDAs were tested for significance with a Monte Carlo Permutation 
test (1000 permutations). The pure effects were calculated directly using partial RDAs, while the joint effects were obtained by subtraction as suggested by Heikkinen et al. (2005).

As in variation partitioning several variables proved significant within each group, we applied hierarchical partitioning to determine the relative effect of the singular variables splitting the variation explained into independent and joint effects (Chevan \& Sutherland, 1991). In hierarchical partitioning, we used linear regression models and $R^{2}$ as a measure of goodness of fit. The hierarchical partitioning procedure was performed using the 'Hier.part.' package version $0.5-1.0$ (MacNally \& Walsh, 2004), which runs in conjunction with R (available at http://www.Rproject.org). In this analysis, we included only those explanatory variables that proved significant in the stepwise forward selection of variation partitioning. The statistical significance of the independent effects was tested by performing 500 randomisations of the explanatory variables using the $95 \%$ confidence limit of $\mathrm{z}$-scores $(\mathrm{z}=$ [observed value - mean(randomisation)] / SD(randomisation)) as described by MacNally (2002).

\section{Results}

In the 99 investigated hay meadows, we found 237 vascular plants, 43 of which were grasses and 194 forbs. The mean species density was 31.1 per $100 \mathrm{~m}^{2}$, with a minimum of 15 and a maximum of 59 per $100 \mathrm{~m}^{2}$.

The stepwise forward selection within the three sets of variables showed that species density was significantly related $(\mathrm{P}<0.05)$ to the following variables (the direction of the relation is given in parentheses): 1) field management: fertiliser $\mathrm{N}(-)$ and cuts (-), together explaining $40.7 \%$ of the variation; 2) abiotic environment: slope $(+)$, elevation $(+)$, and soil depth $(-)$, capturing $35.8 \% ; 3)$ landscape: urban elements (-) and total edges $(+)$, explaining together $32.8 \%$ of the total variation of species density. The amount of variation explained by the model with all the seven significant variables was $53.4 \%$. The variation partitioning of the full model indicated that all three sets had a significant pure effect on the response variable (Table 2), confirming that species density was controlled by both local and landscape determinants. The management showed the largest pure fraction of explained variation, followed by landscape and abiotic environment. Among the shared effects, the largest part was accounted for by the joint effect of the three sets and by the joint effect of field management with abiotic environment. 
Table 2 Variation partitioning results of vascular plant species density in 99 mown meadows in the Italian Alps.

\begin{tabular}{|c|c|c|c|}
\hline & Variables set ${ }^{\mathrm{a}}$ & $\mathrm{R}^{2}(\%)^{\mathrm{b}}$ & $\mathrm{P}^{\mathrm{c}}$ \\
\hline \multirow{3}{*}{ 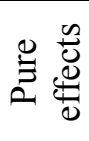 } & $\mathrm{M}$ & 6.7 & 0.001 \\
\hline & E & 5.4 & 0.001 \\
\hline & $\mathrm{L}$ & 6.0 & 0.001 \\
\hline \multirow{6}{*}{ 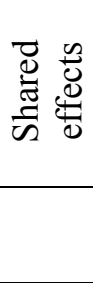 } & $\mathrm{M} \cap \mathrm{E}$ & 8.5 & - \\
\hline & $\mathrm{M} \cap \mathrm{L}$ & 4.9 & - \\
\hline & $\mathrm{E} \cap \mathrm{L}$ & 1.3 & - \\
\hline & $\mathrm{M} \cap \mathrm{E} \cap \mathrm{L}$ & 20.6 & - \\
\hline & TVE & 53.4 & 0.001 \\
\hline & Unexplained & 46.6 & - \\
\hline
\end{tabular}

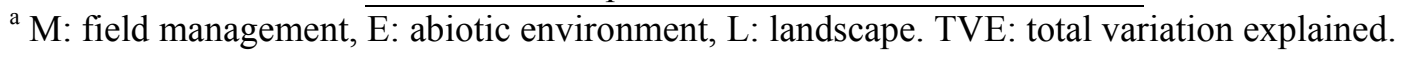

${ }^{\mathrm{b}} \mathrm{R}^{2}$ corresponds to the amount of explained variation (sum of all eigenvalues in pRDAs).

${ }^{c}$ P-value of Monte Carlo Permutation Test $(\mathrm{No}=1000)$. The shared effects were obtained by subtraction and could not be tested for significance.

The results of the hierarchical partitioning demonstrated that a large part of the explained variation was related to joint effects of the explanatory variables. Nevertheless, all the significant predictors within the variation partitioning model had a significant independent contribution. $\mathrm{N}$ fertiliser had the highest independent contribution (10.0\%), followed by slope (4.6\%), urban elements (4.4\%), and cuts (3.6\%). Elevation, soil depth and total edges had only limited pure effects (Fig. 2). Lightly in contrast with variation partitioning results, field management variables had here higher independent contributions. However, the independent effects resulting from hierarchical partitioning were generally comparable to those obtained by the variation partitioning exercise. 


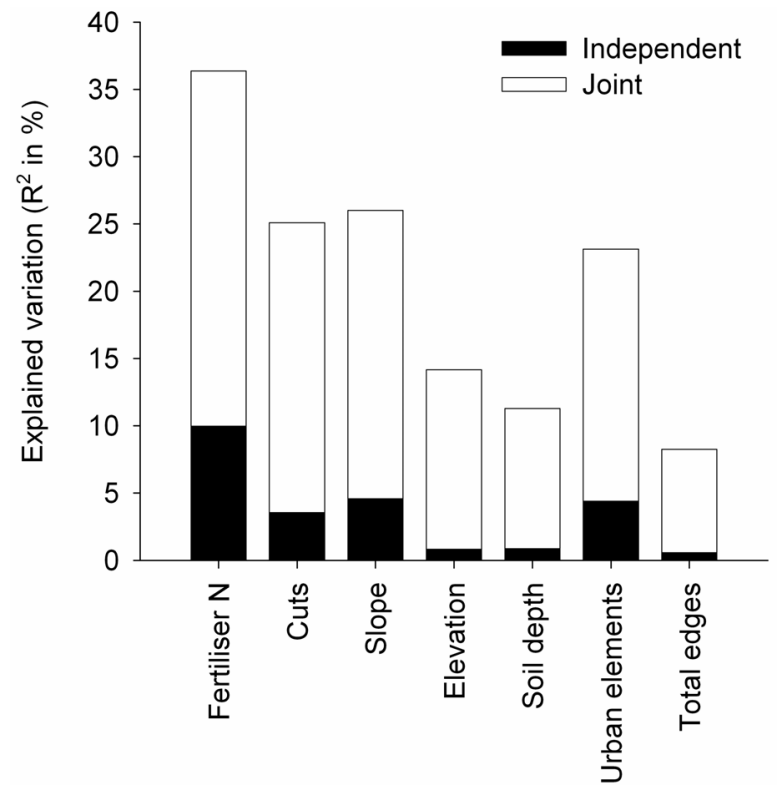

Fig. 2 Independent and joint contributions (given as percentage of $\mathrm{R}^{2}$ ) of the considered determinants for vascular plant species density as estimated by hierarchical partitioning. The data were obtained from 99 meadows in the Italian Alps. All the independent effects were significant (P $<0.05)$ resulting from the z-randomisation procedure $(\mathrm{No}=500)$. Variable names are according to Table 1. Fertiliser $\mathrm{N}$ and urban elements were log-transformed.

\section{Discussion}

In this study, both local and landscape determinants significantly influenced plant species density in the 99 Alpine hay meadows. Vascular plants were primarily controlled by local variables and only secondarily by factors operating at the landscape scale.

In line with our first hypothesis, the results of the partitioning methods suggested that species density was mainly affected by field management and abiotic environment. Both analyses showed that species density tended to increase in less fertilised (Fig. 3a) and less frequently cut meadows. These findings conform to several studies, which found pronounced decreases in species diversity after nutrients enrichment (e.g. Willems \& Nieuwstadt, 1996; Gough et al., 2000). High cutting frequency along with $\mathrm{N}$ fertilisation tends to create a vegetation structure dominated by tall grasses, which reduce the light availability for the smaller plants (Jacquemyn et al., 2003). There is evidence that species richness within a fixed area declines along the fertility gradient due to a generalised increase of plant dimensions (Stevens \& Carson, 1999), or due to different intraspecific competition capabilities for light and resources, which lowers species density by excluding subordinate species 
with low growth rates (Grime, 2001). Site conditions such as steep slopes (Fig. 3b), shallow soils, and increased elevation also contributed to high plant species density. The relatively large pure positive effect of slope indicated that grassland swards on steep slopes were more resistant to invasion by high-growing competitive species than on flatter sites. This was probably due to $\mathrm{P}$ limitation in shallows soils (Bennie et al., 2006). Elevation had only a limited pure effect, indicating that the main part of the variation related to altitude was due to a joint effect with management.

Regarding to our second hypothesis, partitioning results confirmed that landscape context influenced species density significantly due to two contrasting effects. A large proportion of urban elements affected the number of species negatively (Fig. 3c), probably a) by influencing the pool of species adjoining the site, and b) due to a further soil eutrophication. Large areas covered by urban elements could negatively affect the species pool surrounding the meadows as a result of the higher proportion of habitats inhospitable for mown meadow species that were potentially able to disperse into the sites. Although species related to disturbed urban habitats could theoretically enhance the local species pool, the urban flora is characterised by the presence of many ruderal species, against which mown meadows are well buffered (Mucina et al., 1993). The negative relation between the proportion of an inhospitable habitat and grassland species richness conforms to the findings of Söderström et al. (2001), who found a negative relation between a high proportion of arable land and local species richness in pastures. The negative relation between urban elements and species density was possibly even due to an additional nutrient inputs into the meadows located in urbanised and intensive agricultural areas (Stevens, Dise, Mountford, \& Gowing, 2004). These areas act as important source of nutrients, which derive from cowshed emissions and leaks (Whitehead, 1995), vehicular traffic (Truscott, Palmer, McGowan, Cape, \& Smart, 2005), and from the relatively large use of fossil fuels. These nutrients could reach the nearby surfaces through wet and dry atmospheric deposition, run-off or eutrophication of the water table. This hypothesis is supported by the fact that, in the study area, most of the cowsheds were located in areas with a high proportion of urban elements.

Although the landscape variable total edges of meadows had a very limited pure effect on the response variable in comparison to proportion of urban elements, this factor was significantly positively related to species density. Boundaries between habitats are typically accompanied by a transition in the diversity and structural complexity of plant communities (Harper, MacDonald, Burton, Chen, Brosofske et al., 2005), probably hosting a higher number of plants, which could potentially disperse into the meadow site (Saunders, Hobbs, \& Margules, 1991). 

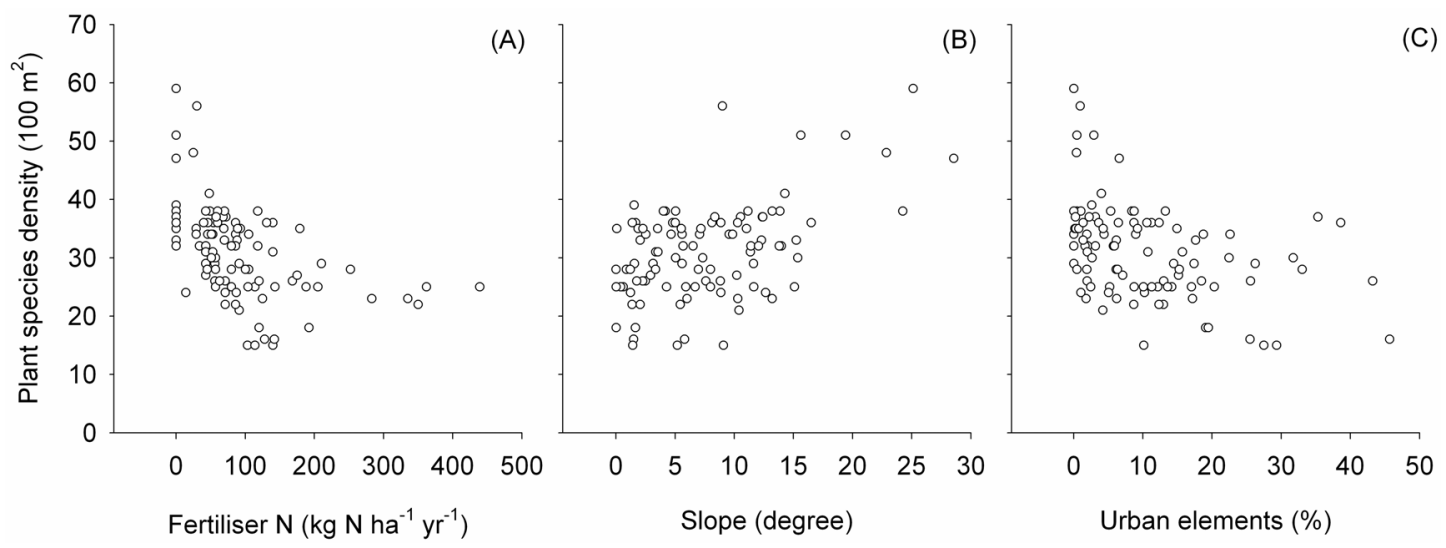

Fig. 3 Scatterplots of vascular plant species density versus the best three predictors according to the hierarchical partitioning results (in all statistical analyses, fertiliser $\mathrm{N}$ and urban elements were logtransformed). The data were obtained from 99 meadows in the Italian Alps.

Our results corroborate the hypothesis that even vascular plants, as several animal taxa, are significantly affected by the landscape context, although the local habitat quality generally explains a greater proportion of the variation in species richness and abundance (Mazerolle \& Villard, 1999). Large areas covered by urban elements in the surrounding landscape of hay meadows reduced species richness of both intensively and extensively managed grassland, stressing the importance of considering both local and landscape determinants for the future management of Alpine meadows. These findings provide useful information for official stakeholders in order to improve the efficiency of management practices to conserve plant species richness. In particular, the introduction of well-targeted compensation payments against intensification and abandonment of the extensively managed and not urbanised sites appeared to be crucial measures to protect speciesrich meadows in the Alpine environments.

\section{Acknowledgements}

We thank all farmers for giving permission to work on their fields. We would like to thank Nicole Wrage (Göttingen - Germany) for her constructive comments and for improving the English. We are grateful to Paolo Rodaro for carrying out the floristic and management surveys, and to Mauro Anesi and Marco Vettori for their support in the field work. This research has been financially supported by the Agricultural Institute of San Michele all'Adige (Trento - Italy), and by the Aldo Gini Foundation (Padova - Italy). GIS data were provided by the Agriculture Department of Trento Province. 


\section{References}

Bennie, J., Hill, M.O., Baxter, R., \& Huntley, B. (2006). Influence of slope and aspect on long-term vegetation change in British chalk grasslands. Journal of Ecology, 94, 355-368.

Chevan, A., \& Sutherland, M. (1991). Hierarchical partitioning. The American Statistician, 45, 9096.

Collins, S.L., Glenn, S.M., \& Briggs, J.M. (2002). Effect of local and regional processes on plant species richness in tallgrass praire. Oikos, 99, 571-579.

Critchley, C.N.R., Chambers, B.J., Fowbert, J.A., Bhogal, A., Rose, S.C., \& Sanderson, R.A. (2002a). Plant species richness, functional type and soil properties of grasslands and allied vegetation in English Environmentally Sensitive Areas. Grass and Forage Science, 57, 82-92.

Critchley, C.N.R., Chambers, B.J., Fowbert, J.A., Sanderson, R.A., Bhogal, A., \& Rose, S.C. (2002b). Association between lowland grassland plant communities and soil properties. Biological Conservation, 105, 199-215.

Dauber, J., Hirsch, M., Simmering, D., Waldhardt, R., Otte, A., \& Wolters, V. (2003). Landscape structure as an indicator of biodiversity: matrix effects on species richness. Agriculture, Ecosystems and Environment, 98, 321-329.

Gotelli, N.J., \& Colwell, R.K. (2001). Quantifying biodiversity: procedures and pitfalls in the measurement and comparison of species richness. Ecology Letters, 4, 379-391.

Gough, L., Osenberg, C.W., Gross, K.L., \& Collins, S.L. (2000). Fertilization effects on species density and primary productivity in herbaceous plant communities. Oikos, 89, 428-439.

Grime, J.P. (2001). Plant strategies, vegetation processes, and ecosystems properties. (2nd ed.). Chichester: John Wiley \& Sons.

Harper, K.A., MacDonald, S.E., Burton, P.J., Chen, J., Brosofske, K.D., Saunders, S.C., Euskirchen, E.S., Roberts, D., Jaiteh, M.S., \& Esseen, P.-A.. (2005). Edge influence on forest structure and composition in fragmented landscapes. Conservation Biology, 19, 768-782.

Heikkinen, R.K., Luoto, M., Kuussaari, M., \& Pöyry, J. (2005). New insights into butterflyenvironment relationships using partitioning methods. Proceedings of the Royal Society B, 272, 2203-2210.

Jacquemyn, H., Brys, R., \& Hermy, M. (2003). Short-time effects of different management regimes on the response of calcareous grassland vegetation to increased nitrogen. Biological Conservation, 111, 137-147. 
Kleijn, D., \& van Langevelde, F. (2006). Interacting effects of landscape context and habitat quality on flower visiting insects in agricultural landscapes. Basic and Applied Ecology, 7, 201-214.

Krauss, J., Klein, A.M., Steffan-Dewenter, I., \& Tscharntke, T. (2004). Effects of habitat area, isolation, and landscape diversity on plant species richness of calcareous grasslands. Biodiversity and Conservation, 13, 1427-1439.

Lepš, J. (2005). Diversity and ecosystem function. In: E. van der Maarel (Ed.), Vegetation ecology, (pp. 199-237). Malden: Blackwell.

Li, H., \& Wu, J. (2004). Use and misuse of landscape indices. Landscape Ecology, 19, 389-399.

MacNally, R. (2000). Regression and model-building in conservation biology, biogeography and ecology: the distinction between - and reconciliation of - 'predictive' and 'explanatory' models. Biodiversity and Conservation, 9, 655-671.

MacNally, R. (2002). Multiple regression and inference in ecology and conservation biology: further comments on identifying important predictor variables. Biodiversity and Conservation, 11, 1397-1401.

MacNally, R., \& Walsh, C. (2004). Hierarchical partitioning public-domain software. Biodiversity and Conservation, 13, 659-660.

Mazerolle, M.A., \& Villard, M. (1999). Patch characteristics and landscape context as predictors of species presence and abundance: a review. Ecoscience, 6, 117-124.

McGarigal, K., Cushman, S.A., Neel, M.C., \& Ene, E. (2002). FRAGSTATS: Spatial Pattern Analysis Program for Categorical Maps. Computer software program produced by the authors at the University of Massachusetts, Amherst. Available at the following web site: www.umass.edu/landeco/research/fragstats/fragstats.html.

Mucina, L., Grabherr, G., \& Ellmauer, T. (Eds.) (1993). Die Pflanzengesellschaften Österreichs. Jena: Gustav Fischer Verlag.

Myklestad, Å., \& Sætersdal, M. (2004). The importance of traditional meadow management techniques for conservation of vascular plant species richness in Norway. Biological Conservation, 118, 133-139.

Prosser, F. (2001). Lista rossa della flora del Trentino. Pteridofite e fanerogame. Museo Civico di Rovereto. Trento: Edizioni Osiride.

Roschewitz, I., Gabriel, D., Tscharntke, T., \& Thies, C. (2005). The effects of landscape complexity on arable weed species diversity in organic and conventional farming. Journal of Applied Ecology, 42, 873-882. 
Rosenzweig, M.L. (1995). Species diversity in space and time. Cambridge: Cambridge University Press.

Saunders, D.A., Hobbs, R.J., \& Margules, C.R. (1991). Biological consequences of ecosystem fragmentation: a review. Conservation Biology, 5, 18-32.

Sboarina, C., \& Cescatti, A. (2004). Il clima del Trentino. Distribuzione spaziale delle principali variabili climatiche. Report 33. Trento: Centro di Ecologia Alpina.

Scotton, M., Marini, L., Pecile, A., Franchi, R., \& Fezzi, F. (2005). Notes on the floral evolution of the manured meadows in the Sole Valley (Trentino, NE Italy). Grassland Science in Europe, 10, 525-528.

Sebastiá, M.T. (2004). Role of topography and soils in grassland structuring at the landscape and community scales. Basic and Applied Ecology, 5, 331-346.

Söderström, B., Svensson, B., Vessby, K., \& Glimskär, A. (2001). Plants, insects and birds in seminatural pastures in relation to local habitat and landscape factors. Biodiversity and Conservation, $10,1839-1863$.

Stevens, M.H.H., \& Carson, W.P. (1999) Plant density determines species richness along an experimental fertility gradient. Ecology, 80, 455-465.

Stevens, C.J., Dise, N.B., Mountford, J.O., \& Gowing, D.J. (2004). Impact of nitrogen deposition on the species richness of grasslands. Science, 303, 1876-1879.

Strijker, D. (2005). Marginal lands in Europe - causes of decline. Basic and Applied Ecology, 6, 99-106.

Tasser, E., \& Tappeiner, U. (2002). Impact of land use changes on mountain vegetation. Applied Vegetation Science, 5, 173-184.

Ter Braak, C.J.F., \& Šmilauer, P. (2002). CANOCO Reference manual and CanoDraw for Windows User's guide: Software for Canonical Community Ordination (version 4.5). Ithaca: Microcomputer Power.

Truscott, A.M., Palmer, S.C.F., McGowan, G.M., Cape, J.N., \& Smart, S. (2005). Vegetation composition of roadside verges in Scotland: the effects of nitrogen deposition, disturbance and management. Environmental Pollution, 136, 109-118.

Tscharntke, T., Klein, A.M., Kruess, A., Steffan-Dewenter, I., \& Thies, C. (2005). Landscape perspectives on agricultural intensification and biodiversity - ecosystem service management. Ecology Letters, 8, 857-874. 
Walther, U., Menzi, H., Ryser, J.-P., Flisch, R., Jeangros, B., Maillard, A., Siegenthaler, A., \& Vuilloud, P.A. (1994). Grundlagen für die Düngung im Acker- und Futterbau. Agrarforschung, $1,1-40$.

Weibull, A.-C., Östman, Ö., \& Granqvist, Å. (2003). Species richness in agroecosystems: the effect of landscape, habitat and farm management. Biodiversity and Conservation, 12, 1335-1355.

Whitehead, D.C. (1995). Grassland Nitrogen. Wallingford: CAB International.

Whittaker, R.J., Willis, K.J., \& Field, R. (2001). Scale and species richness: towards a general hierarchical theory of species diversity. Journal of Biogeography, 28, 453-470.

Willems, J.H., \& van Nieuwstadt, M.G.L. (1996). Long-term after effects of fertilization on aboveground phytomass and species diversity in calcareous grassland. Journal of Vegetation Science, 7, 177-184. 
SUMMARY

During the last decades, both the decrease of the area and the fragmentation of semi-natural habitats in Central Europe caused a dramatic decline of biodiversity at local and regional scales. These processes have been largely attributed to the intensification of land-use practices. More recently, the pressure of agricultural intensification has increased by abandonment of many low-productivity semi-natural grasslands that no longer ensured sufficient economic yields. At the local field scale, management intensification resulted in simplified, species-poor grassland communities of low nature conservation value, mainly due to high nutrient input and increased defoliation frequency. At the landscape and regional scale, management intensification had a profound influence by creating relatively simple and homogeneous landscapes dominated by arable fields.

In this study, we examined the relative importance of local field management, topographic and landscape variables on grassland species of different management regimes, focusing on both vascular plant species richness and species composition. In addition, we analysed the effect of management regime (meadow vs. pasture) on local-regional patterns of species diversity to provide understanding of the contribution of different management regimes to total observed regional species diversity. Finally, we investigated the relative importance of local and landscape factors on species diversity of mown meadows in an area of the Southern Alps. The data were analysed using different univariate and multivariate statistical procedures.

The study was conducted in the rural district of Northeim in Lower Saxony, Germany, and in several districts of the Trento Province, NE Italy. The Northeim district is characterised by a large proportion of arable land and forest, interposed with patchily distributed fragments of grassland. Managed grassland sites were sampled at random, covering a complete gradient from agriculturally improved, species-poor grassland to semi-natural, species-rich grassland that had not experienced agricultural improvement. In the Italian study area, the investigated meadows covered a large gradient of management intensity and elevation.

Three major findings emerged from the study concerning the analyses in the rural district of Northeim. (1) Local field management such as low application rates of nitrogen fertilisers contributed to high plant species richness in grasslands, and this effect was much more pronounced for meadows than for pastures. This indicated that high amounts of nitrogen fertilisers caused more 
competitive exclusion in grasslands protected from herbivory. Moreover, species richness of pastures was positively related to local abiotic site conditions like soils with a low nutrient status and steep slopes. (2) Landscape context showed a strong effect on plant species richness in pastures. Species richness of pastures significantly decreased with increasing percentage of arable land in the surrounding landscape, whereas species richness of meadows was not affected by landscape context. This suggested that both the dispersal by grazing animals and the colonisation of vegetation gaps after disturbance were negatively affected by a high percentage of arable land in the surrounding landscape of pastures. (3) Heterogeneity between the grassland sites at the regional scale contributed the most to overall observed species diversity, indicating considerable differences in plant community composition among the investigated sites. The analysis of management effects revealed that low-to-moderate livestock grazing contributed indirectly to high species richness as pastures were mainly located on steeply sloping grounds with poor soil quality. Analyses of Alpine meadows further revealed that plant species diversity was strongly related to the soil phosphorous content and elevation.

Thus, to improve the ability to explain variation in patterns of vascular plant diversity in managed grasslands, there is an urgent need to conduct analyses at multiple spatial scales. This study further implies that future management policies should consider both a reduction of nitrogen fertilisation at the local scale and the maintenance of large scale pasture systems at the regional scale to enable the conservation of a wide diversity of grassland plants. 


\section{ZUSAMMENFASSUNG}

In den letzten Jahrzehnten verursachten sowohl der Flächenrückgang als auch die Fragmentierung von halbnatürlichen Habitaten in Mitteleuropa einen dramatischen Rückgang der Biodiversität auf lokalen und regionalen Skalenebenen. Diese Prozesse wurden hauptsächlich auf die Intensivierung der landwirtschaftlichen Produktion zurückgeführt. Zunehmende Anforderungen an die Rentabilität der landwirtschaftlichen Nutzung haben zusätzlich zu einer Nutzungsaufgabe von ertragsschwachen halbnatürlichen Grünlandhabitaten geführt. Auf der lokalen Skalenebene hat die Intensivierung der Bewirtschaftung durch hohe Nährstoffeinträge und eine erhöhte Entblätterungshäufigkeit zu vereinfachten, artenarmen Grasslandgesellschaften mit geringem Naturschutzwert geführt. Hingegen hat die Intensivierung der Bewirtschaftung auf der landschaftlichen und regionalen Skalenebene tief greifende Veränderungen verursacht, indem relativ einfache und homogene Landschaften geschaffen wurden, die von ackerbaulich genutzten Flächen bestimmt werden.

In dieser Arbeit wurde die relative Bedeutung von lokalen Bewirtschaftungsvariablen, topographischen Variablen und Landschaftsvariablen auf Grünlandarten unterschiedlicher Bewirtschaftungsregime untersucht. Die Auswertungen konzentrierten sich sowohl auf den Artenreichtum als auch auf die Artenzusammensetzung. Darüber hinaus analysierten wir den Effekt des Bewirtschaftungsregimes (Wiese vs. Weide) auf lokal-regionale Muster der Artenvielfalt, um Kenntnisse über den Beitrag von unterschiedlichen Bewirtschaftungsregimen für die gesamte in der Region gemessene Artenvielfalt zu gewinnen. Letztlich untersuchten wir zudem die relative Bedeutung von lokalen und landschaftlichen Faktoren für die Artenvielfalt von gemähten Wiesen in einer Region in den südlichen Alpen. Die Daten wurden unter Verwendung unterschiedlicher univariater und multivariater statistischer Analyseverfahren ausgewertet.

Die Untersuchung fand in dem ländlich geprägtem Landkreis Northeim in Südniedersachsen, Deutschland, und zusätzlich in mehreren Kreisen der Provinz Trento im nordöstlichen Italien statt. Der Landkreis Northeim ist durch einen hohen Anteil von Acker- und Waldflächen geprägt, in denen fragmentierte Grünlandflächen auftreten. Die untersuchten bewirtschafteten Grünlandflächen wurden zufällig ausgewählt und deckten den gesamten Gradienten vom artenarmen Wirtschaftsgrünland bis zum halbnatürlichen artenreichen Grünland, das weniger intensiv 
bewirtschaftet wurde, ab. In dem italienischen Untersuchungsgebiet deckten die untersuchten Wiesen einen großen Gradienten an Bewirtschaftungsintensität und Höhenlage ab.

Aus den Analysen im Landkreis Northeim gingen drei wesentliche Ergebnisse hervor. (1) Lokale Bewirtschaftungsparameter wie eine geringe Stickstoffdüngung bewirkten einen hohen Artenreichtum auf Grünlandflächen, und dieser Effekt war wesentlich deutlicher auf Wiesen als auf Weiden ausgeprägt. Dies deutete darauf hin, dass hohe Stickstoffgaben einen verstärkten Ausschluss von Arten durch Konkurrenz auf Flächen verursachten, die nicht beweidet wurden. Darüber hinaus erhöhten lokale abiotische Standortfaktoren wie nährstoffarme Böden und steile Hanglagen den Artenreichtum von Weiden. (2) Der Landschaftskontext zeigte einen starken Effekt auf den Artenreichtum von Weiden. Der Artenreichtum von Weiden verringerte sich signifikant mit einem erhöhten Anteil von Ackerflächen in der Umgebung der Fläche, wohingegen der Artenreichtum von Wiesen nicht durch den Landschaftskontext beeinflusst wurde. Dies deutete darauf hin, dass sowohl die Ausbreitung von Arten durch Weidetiere als auch die Kolonisierung von Lücken im Bestand nach Störungseinflüssen, durch einen hohen Anteil von Ackerflächen in der umgebenden Landschaft verringert wird. (3) Die Heterogenität zwischen den untersuchten Grünlandflächen auf der regionalen Skalenebene leistete den größten Beitrag zu der gesamten in der Region gemessenen Artenvielfalt. Dies deutete auf hohe Unterschiede in der Artenzusammensetzung der untersuchten Grünlandflächen hin. Die Analyse von Bewirtschaftungseffekten zeigte einen indirekten positiven Effekt einer niedrigen bis mittleren Beweidungsintensität auf den Artenreichtum, der darin begründet lag, dass die beweideten Flächen sich vorrangig auf steilen Flächen mit nährstoffarmen Böden befanden. Die Analysen der alpinen Wiesen zeigten zudem, dass der Phosphorgehaltes im Boden und die Höhenlage der untersuchten Grünlandflächen einen starken Einfluss auf die Artenvielfalt haben.

Um die Variation in den Mustern der Artenvielfalt besser erklären zu können, weisen die Ergebnisse dieser Untersuchung deutlich darauf hin, dass es erforderlich ist, Analysen unter Berücksichtigung verschiedener räumlicher Skaldenebenen durchzuführen. Diese Arbeit deutet zudem an, dass zukünftige Strategien der Landbewirtschaftung sowohl die Reduzierung der Stickstoffdüngungsmengen auf der lokalen Skalenebene als auch die Erhaltung von großflächigen Beweidungssystemen auf der regionalen Skalenebene anstreben sollten. Diese Maßnahmen könnten einen wirksamen Beitrag zum Erhalt einer hohen Vielfalt von Grünlandarten leisten. 


\section{ACKNOWLEDGEMENTS}

This thesis was embedded in the BIOPLEX (Biodiversity and spatial complexity in agricultural landscapes under global change) project funded by the German BMBF (Federal Ministry of Education and Science). Carrying out my part within the BIOPLEX project would have been impossible without the continuing support and encouragement by numerous people during the past three years.

First, I sincerely wish to express my gratitude to my supervisor Prof. Dr. Johannes Isselstein for his willingness to spend numerous hours guiding me throughout the thesis. I want to thank him for providing ideas, constructive comments and also for the general interest he has shown in my work. My gratitude also goes to Prof. Dr. Teja Tscharntke for co-reviewing my thesis.

Lorenzo Marini from the Department of Environmental Agronomy and Crop Production at the University of Padova in Italy greatly improved this thesis. While he was in receipt of a grant from the Aldo Gini foundation from Italy, we spent plenty of time in Göttingen during the summer 2006 to gain deepened insight into multivariate statistics. Although the Azzurri won the football World Cup, the fruitful cooperation proved valuable for both planning and writing of manuscripts.

My gratitude also goes to Dr. Martina Hofmann, who assisted me predominantly at the beginning of the thesis and guided me during my first steps in multivariate statistics. I thank Dr. Nicole Wrage for correcting the English and commenting on manuscripts. With Anne Richter gen. Kemmermann I had a nice time in the office and I want to thank her for discussions and cooperation during the time shared at the Research Centre for Agriculture and the Environment.

Fieldwork was carried out in the study region during the summers of 2002 and 2004. In particular, I want to thank Dr. Elke Bertke and Anne Richter gen. Kemmermann for their hard work. Among many others, I would like to thank Bernd Gehlken, Sonja Biewer, Rebecca Ulrich, Michelle Schröder and Traudi Mathias. This thesis would not have been possible without the cooperation of the farmers and their unrestricted willingness to answer numberless questions.

Special thanks also to Prof. Dr. Bärbel Gerowitt, Dr. Horst-Henning Steinmann, PD Dr. Carola Pekrun, Dr. Friedrike De Mol, Elke Schröder, Jan Freese and Oliver Correll for providing a nice working atmosphere at the Research Centre for Agriculture and the Environment and all the people 
who were involved in the project, in particular Dr. Jens Dauber, Dr. Carsten Thies, Dr. Martin Schmidt and Dr. Doreen Gabriel.

Dr. Heike Culmsee, Dominik Cullmann, Prof. Dr. Joachim Saborowski and Dr. Boris Schröder gave advice and comments concerning the statistics, and PD Dr. Jürgen Böhner, Dr. Susanne Kickner and numerous members of the ClubUNIGIS e-mail list helped me to solve problems related to spatial analyses by means of Geographic Information Systems. PD Dr. Michael Kessler is acknowledged for his cooperative help in defining appropriate measures of biological diversity.

Finally, my warmest thanks go to Swena Bonorden with whom I shared fantastic moments and our son Jonas. Above all, I thank my mother and father for their trust and support in my endeavours. 


\section{LIST OF PUBLICATIONS}

\section{Scientific articles (in preparation)}

Klimek, S., Marini, L., Hofmann, M. \& Isselstein, J. Effects of management regime, nitrogen fertilisation and abiotic factors on local-regional patterns of plant species richness in managed temperate grasslands.

\section{Scientific articles (peer-reviewed)}

Klimek, S., Marini, L. \& Isselstein, J. Opposing effects of local and landscape factors on plant species richness in mown vs. grazed grassland. (submitted to Journal of Applied Ecology).

Klimek, S., Hofmann, M., Isselstein, J. \& Richter gen. Kemmermann, A. Plant species richness and composition in managed grasslands: the relative importance of field management and environmental factors. Biological Conservation (in press).

Scotton, M., Marini, L, Klimek, S. \& Pecile, A. Patterns of plant species density in Alpine hay meadows: local vs. landscape controls. (submitted to Basic and Applied Ecology).

Marini, L., Scotton, M., Klimek, S. \& Isselstein, J. Effects of local factors on plant species richness and composition of Alpine meadows. Agriculture, Ecosystems \& Environment (in press).

Marini, L., Nascimbene, J., Scotton, M. \& Klimek, S. Hydrochemistry, water table depth, and related distribution patterns of vascular plants in a mixed mire. (submitted to Folia Geobotanica).

\section{Other scientific articles}

Klimek, S. (2006). Contrasting response of plant biodiversity of different grassland management regimes to local and landscape factors: Potential implications for management and conservation. In: Mitteilungen der Gesellschaft für Pflanzenbauwissenschaften, Band 18, pp. 150-153.

Klimek, S., Marini, L. \& Isselstein, J. (2006). Effects of local and landscape factors on plant species richness in contrasting grassland management regimes. Verhandlungen der Gesellschaft für Ökologie, Band 36, p. 122. 
Klimek, S., Isselstein, J. \& Steinmann, H.-H. (2006). Effects of field management, environment and landscape context on vascular plant species diversity in managed grasslands. IOBC wprs Bulletin, Vol. 29 (6), pp. 69-72.

Klimek, S., Richter gen. Kemmermann, A., Bertke, E. \& Isselstein, J. (2005). Plant species richness in grasslands - Relative importance of local site conditions and landscape structure. International Conference of the Collaborative Research Center SFB 299 "Multifunctionality of Landscapes Analysis, Evaluation, and Decision Support", 18. - 19. 05. 2005, Gießen, Germany. Book of Abstracts, p 35 .

Klimek, S. \& Richter gen. Kemmermann, A. (2005). The relative importance of management and the environment on plant species richness in managed grasslands. In: Mitteilungen der Arbeitsgemeinschaft Grünland und Futterbau, Band 7, pp. 234-237.

Richter gen. Kemmermann, A., Klimek, S., Bertke, E. \& Isselstein, J. Auctioning ecological goods within agri-environmental schemes - a new approach and its implementation in species-rich grasslands. In: Meyer, B.C. (Eds.), Sustainable Land Use in Intensively Used Agricultural Regions. Wageningen. (in press).

Bathke, M., Brahms, E., Diekmann, M., Drachenfels, O.V., Garve, E., Hertwig, R., Horr, C., Isselstein, I., Keienburg, T., Kleine-Limberg, W., Klimek, S., Most, A., Prasse, R:, Prüter, J., Richter Gen. Kemmermann, A., Schreiner, J., Steinmann, H.-H., Wicke, G., Wittig, B. \& Zacharias, D. (2006). Entwicklung einer Kennartenliste für die ergebnisorientierte Honorierung im Grünland Nordwestdeutschlands. In: Keienburg, T., Most, A., Prüter, J. (in Vorb.) [Hrsg.]: Entwicklung und Erprobung von Methoden für die ergebnisorientierte Honorierung ökologischer Leistungen im Grünland Nordwestdeutschlands- - NNA-Berichte 19. Jg., H. 1, Schneverdingen.

Richter gen. Kemmermann, A., Gehlken, B., Klimek, S., Steinmann, H.-H. \& Isselstein, J. (2006). Fachlich-methodische Grundlagen der ergebnisorientierten Honorierung im Grünland Beispielregion Landkreis Northeim. In: Keienburg, T., Most, A., Prüter, J. (in Vorb.) [Hrsg.]: Entwicklung und Erprobung von Methoden für die ergebnisorientierte Honorierung ökologischer Leistungen im Grünland Nordwestdeutschlands- - NNA-Berichte 19. Jg., H. 1, Schneverdingen.

Richter gen. Kemmermann, A., Klimek, S., Bertke, B. \& Isselstein, J. (2005). Conceptual design and results of an outcome-based payment scheme for ecological services of agriculture. In: Mitteilungen der Arbeitsgemeinschaft Grünland und Futterbau, Band 7, pp. 250-253. 


\section{CURRICULUM VITAE}

Sebastian Klimek

born 18.05.1974 in Marburg, Germany

since 01/2004 PhD Study at the Research Centre for Agriculture and the Environment, Faculty of Agricultural Sciences, Georg-AugustUniversity Goettingen, under the supervision of Prof. Dr. Johannes Isselstein

Thesis:

" Effects of local and landscape factors on grassland plant diversity "

07/2003-12/2003 Research fellow at the Research Centre for Agriculture and the Environment, Faculty of Agricultural Sciences, Georg-AugustUniversity Goettingen

12/2002 - 06/2003 UNIGIS Postgraduate Certificate at the University of Salzburg (UNIGIS professional)

01/2002 - 11/2002 Positions as Student assistant:

- Department of Geodesy and Geoinformatics, Faculty for Agricultural and Environmental Sciences, University of Rostock

- German Oceanographic Museum, Stralsund

- Agricultural Analysis and Research Institute, Rostock

10/1995 - 12/2001 Diploma Study of Agroecology at the Faculty for Agricultural and (Tertiary education) Environmental Sciences, University of Rostock, Germany

Thesis (English title):

" GIS-based analysis of multitemporal LANDSAT-TM images for applications in Precision Farming "

Supervisors: Prof. Dr.-Ing. Ralf Bill and Dr.-Ing. Görres Grenzdörffer

1984 - $1993 \quad$ Gymnasium Philippinum, Marburg, Germany

(Secondary education) 1993 Matriculation 